\title{
Wewnętrzna jawność postępowań rehabilitacyjnych z perspektywy oskarżonego i jego obrońcy
}

\begin{abstract}
The article touches upon the issue of internal transparency of rehabilitation proceedings and reinvestigations which take place following the annulment of the final judgment. Depending on the rehabilitation prerequisites, it is possible to obtain an acquittal or a judgment equal to an acquittal in three exceptional and appeal modes, i.e. cassation, revision and annulment with regard to persons who experienced repression on the grounds of their involvement in actions aimed at maintaining the independence of the Republic of Poland. The full inclusion of the defendant and their defender in the court proceedings guarantees that the efforts to expunge the defendant's criminal record will be carried out in accordance with the rules of directness, contradictoriness, equality, orality, the right to defense and broadly understood rule of conscientiousness. This type of procedure upholds the possibility of voluntary participation of the defendant in proceedings aimed at establishing the probability or certainty of the emergence of grounds for employing exceptional appeal modes, while the restrictions, exclusion or expansion of the involvement of the defendant are regulated according to particular exceptions.
\end{abstract}

Key words: internal transparency of rehabilitation proceedings, the defendant, the defender, cassation, revision, rule of directness, rules of directness, rule of equality, rule of orality, the right to defense rule of fair trial

\section{Pojęcie rehabilitacji i postępowań rehabilitacyjnych}

Nazwa „rehabilitacja” obejmuje szereg różnych desygnatów. Cechą wspólną wszystkich potencjalnych definicji wydają się być konsekwencje zastosowania instytucji. Samoistny lub generowany wraz ze współwystępująca instytucją zatarcia skazania skutek uruchomienia procedury rehabilitacyjnej stanowi unicestwienie sankcji karnych utraconych na podsta- 
wie prawomocnego wyroku sądowego - w konsekwencji zaś odzyskanie przez skazanego statusu osoby niekaranej. Poszczególne desygnaty definiowanego pojęcia różnicuje metoda stosowana celem utraty stygmatu osoby karanej oraz motywy uzasadniające przywrócenie praw utraconych na skutek prawomocnego skazania. Podziały instytucji rehabilitacji powstałe wskutek zastosowania tych kryteriów nie mają charakteru rozłącznego. Pomiędzy różnymi typami rehabilitacji, powstałymi wskutek odwołania się do trybu i motywów przywrócenia praw utraconych lub ograniczonych prawomocnym wyrokiem sądu, zachodzi stosunek krzyżowania każdy typ mechanizmu służącego odzyskaniu statusu osoby niekaranej, wyodrębniony $\mathrm{w}$ rezultacie zastosowania kryterium odwołującego się do trybu, może być wykorzystany ze wszystkich powodów generalnie usprawiedliwiających unicestwienie konsekwencji skazania.

Posługując się kryterium odwołującym się do trybu unicestwiania zastosowanych sankcji karnych, można wyodrębnić trzy ewolucyjne, tj. kolejno po sobie wykształcone, formy rehabilitacji skazanego:

a) rehabilitacja następująca $\mathrm{w}$ drodze łaski stosowanej przez czynnik władczy;

b) rehabilitacja ustawowa oraz

c) rehabilitacja sędziowska ${ }^{1}$.

Ad. a. Formalne pozbawienie stygmatu osoby karanej poprzez zastosowanie prawa łaski stanowi prerogatywę głowy państwa lub innego najwyższego organu władzy państwowej. Istotą instytucji unicestwienia negatywnych skutków skazania $\mathrm{w}$ drodze arbitralnej decyzji organu władzy jest tzw. restytucja, tzn. następujące ze skutkiem ex tunc darowanie kary już wykonanej.

Ad. b. Ustawowe przywrócenie praw utraconych wskutek skazania następuje ipso iure po wypełnieniu przez skazanego wskazanych ustawą przesłanek - zwykle po upływie pewnego minimalnego, wskazanego przepisem odcinka czasowego, liczonego od momentu odbycia całości kary, jej darowania bądź też przedawnienia wykonania. Utrata stygmatu osoby karanej odbywa się automatycznie, bez potrzeby jej potwierdzenia deklaratywnym orzeczeniem sądu.

Ad. c. Czynnością przywracającą skazanego do grona osób niekaranych $\mathrm{w}$ systemie rehabilitacji sądowej jest orzeczenie sądu podejmowane na wniosek skazanego lub osób uprawnionych do działania na jego korzyść. Sędziowską decyzję o unicestwieniu wszelkich skutków skaza-

1 J. Makarewicz: Prawo karne ogólne. Kraków 1914, s. 272-280; Idem: Prawo karne. Wykład prawnoporównawczy z uwzględnieniem prawa obowiązującego $w$ Rzeczypospolitej Polskiej. Warszawa 1924, s. 268-290. 
nia warunkuje stwierdzenie in casu zaistnienia abstrakcyjnie i generalnie określonych ustawą przesłanek rehabilitacji ${ }^{2}$.

Kryterium bazujące na powodach towarzyszących przywracaniu praw utraconych lub ograniczonych wskutek prawomocnego skazania ma charakter aksjologiczny. Indywidualne decyzje głowy państwa przywracające prawa osobie oznaczonej co do tożsamości lub generalne i abstrakcyjne określenie w ustawie przesłanek powrotu do grona osób niekaranych zwykle warunkuje potrzeba realizacji istotnych dla decydenta wartości - bądź to naruszonych $\mathrm{w}$ procesach sfinalizowanych skazaniem, bądź też zaistniałych już po wydaniu prawomocnego wyroku lub po wykonaniu kar i środków karnych orzeczonych z tytułu popełnienia przestępstwa. Użycie kryterium odwołującego się do wartości uzasadniających formalne puszczenie $\mathrm{w}$ niepamięć faktu popełnienia przestępstwa pozwala wyodrębnić następujące rodzaje rehabilitacji skazanego:

a) rehabilitacja motywowana miłosierdziem;

b) rehabilitacja uzasadniona potrzebą realizacji sprawiedliwości formalnej lub materialnej, naruszonej w indywidualnym procesie skazanego;

c) rehabilitacja następująca ze względu na konieczność uczynienia zadość sprawiedliwości materialnej naruszonej na masową skalę w procesach określonej kategorii osób skazanych ${ }^{3}$.

Ad. a. Względy miłosierdzia pozwalają zrehabilitować osoby prowadzące nienaganny tryb życia w okresie przypadającym po odbyciu całości sankcji zastosowanych adekwatnie do wagi przestępstwa w prawidłowo przebiegającym procesie oznaczonego sprawcy. Prawidłowe pod względem formalnym i materialnym ukaranie rzeczywistego sprawcy jest, co prawda, zgodne z zasadą sprawiedliwości komutatywnej rządzącej państwowym wymiarem sprawiedliwości. Ten, reagując na popełnienie przestępstwa, powinien bowiem zastosować wobec burzyciela istniejącego porządku sankcje statuowane przepisami prawa, odpowiednio odpłacając za wyrządzone $z^{4}{ }^{4}$. Jednakże przywrócenie stanu sprzed popełnienia przestępstwa, następujące po odbyciu kar i wykonaniu orzeczonych

${ }^{2}$ Ibidem, s. 269; Z. PAPIERKOWSKI: Rehabilitacja i zatarcie skazania a zniestawienie. Warszawa 1934, s. 1-10.

${ }^{3}$ L. WiLK: Ustawowa rehabilitacja osób represjonowanych za działalność na rzecz niepodległości Polski. „Probl. Prawa Karnego” 1993, z. 19, s. 63.

${ }^{4}$ Arystoteles: Etyka nikomachejska. Ksiegga V. Tłum. D. Gromska. W: Idem: Dzieła wszystkie. Warszawa 2002, 1137b, s. 175; T. BANASzczyK: Pojęcie sprawiedliwości u Arystotelesa. „Studia filozoficzne” 1973, z. 1, s. 152; M. OssowsKa: Normy moralne. Próba systematyzacji. Warszawa 1985, s. 144; C. Perelman: O sprawiedliwości. Warszawa 1959, s. 36; W. SAdurski: Teoria sprawiedliwości. Podstawowe zagadnienia. Warszawa 1988, s. 25. R.A. TокаRсzYк: Filozofia prawa w perspektywie prawa natury. Białystok 1997, s. 177; Z. Ziembińsкi: O pojmowaniu sprawiedliwości. Lublin 1992, s. 126; IDEM: Sprawiedliwość społeczna jako pojęcie prawne. Warszawa 1996, s. 13. 
środków karnych, oraz nieposzlakowany tryb życia prowadzony przez sprawcę w okresie późniejszym, powodują, że utrzymywanie statusu osoby karanej - jakkolwiek stanowiące sprawiedliwą odpłatę za naruszenie porządku prawnego - staje się niesłuszne ${ }^{5}$.

Miłosierne korygowanie sprawiedliwie dokonanej alokacji kary w reakcji za popełnione przestępstwo może stanowić podłoże każdego trybu rehabilitacji. Arbitralna decyzja najwyższego czynnika władzy pozbawiająca stygmatu osoby karanej najczęściej jest podejmowana właśnie ze względu na nienaganny tryb życia prowadzony przez sprawcę po odcierpieniu zastosowanych kar i innych środków represji karnej. Z kolei najczęściej występującym założeniem automatycznego, tj. następującego ipso iure, mechanizmu uchylającego wszelkie skutki skazania jest ustawowa presumpcja - jej poprzednikiem jest upływ czasu, fakt domniemywany stanowi zaś pozytywna prognoza co do niepopełniania w przyszłości kolejnych przestępstw przez rehabilitowanego ${ }^{6}$. Także warunek rehabilitacji sędziowskiej stanowi wykonanie wszelkich kar i innych środków represji karnej zastosowanych wobec skazanego oraz rzeczywiste nienaganne zachowanie rehabilitowanego w ciągu określonego odcinka czasu, stanowiącego najczęściej określoną w ustawie część wymiaru kary orzeczonej wobec sprawcy. Rehabilitacja sędziowska nie opiera się na domniemaniu, lecz na rzeczywiście poprawnym trybie życia prowadzonym przez skazanego po wykonaniu sankcji karnych. Metodą pozwalającą sędziemu decydującemu o przywróceniu do grona osób niekaranych uzyskać pewność co do zaistnienia tej przesłanki jest monitorowanie zachowania skazanego przez wskazany ustawą okres próby ${ }^{7}$. Mutacją tej formy rehabilitacji jest instytucja tzw. wolności dozorowanej. W systemie kontrolowanego pozostawienia skazanego na wolności sędziowska decyzja o pozbawieniu stygmatu osoby karanej jest podejmowana wobec nienagannie zachowującego się sprawcy - nie po wykonaniu całości represji karnych orzeczonych prawomocnym wyrokiem, lecz po próbnym zwolnieniu skazanego przed zakończeniem wykonania kary lub zaraz po jej orzeczeniu i równoczesnej rezygnacji z realizacji zastosowanych sankcji ${ }^{8}$.

${ }_{5}^{5}$ Z. PAPIERKOWsKi: Rehabilitacja i zatarcie skazania a zniesławienie..., s. 1.

${ }^{6}$ J. Makarewicz: Prawo karne ogólne..., s. 272; IDEM: Prawo karne. Wykład prawnoporównawczy..., s. 268-290.

7 J. MaKarewicz: Prawo karne ogólne..., s. 272; IDem: Prawo karne. Wykład prawnoporównawczy..., s. 268-270.

${ }^{8}$ L. LERNELL: Wyktad prawa karnego. Część ogólna. Warszawa 1961, s. 318; M. MaKowsKI: Prawo karne - Część ogólna (Wykład prawnoporównawczy prawa karnego austriackiego, niemieckiego i rosyjskiego obowiq̨zującego $w$ Polsce). Kraków 1924, s. 409; A. MurzYNowski: Ułaskawienie w Polsce Ludowej. Warszawa 1965, s. 30; B. WróBlewski: Penologia - Socjologia kar. T. 1. Wilno 1926, s. 362. 
Ad. b. Przywrócenie praw motywowane względami sprawiedliwości formalnej lub materialnej naruszonej w indywidualnym procesie skazanego, pozwala zrehabilitować osoby skazane wskutek sporadycznych pomyłek wymiaru sprawiedliwości. Prawidłowe rozstrzygnięcie kwestii odpowiedzialności karnej oskarżonego powinno dokonać się wskutek zastosowania uczciwej i rzetelnej procedury gwarantującej osiągnięcie doskonałej sprawiedliwości, tj. skazanie wyłącznie osoby winnej popełnienia przestępstwa i każdorazowego uwolnienia od zarzutu jego realizacji tylko rzekomego sprawcy. Mechanizm sprawiedliwości wyrównującej Arystoteles eksplikuje, twierdząc, że „niesprawiedliwość jest nierównością, którą sędzia stara się wyrównać; bo jeśli ktoś zadał, a kto inny odniósł ranę lub ktoś zabił, a ktoś inny zginął, to zachodzi nierówność między czynem jednego a doznaniem drugiego; sędzia jednak usiłuje usunać za pomocą kary nierówność, umniejszając zysk sprawcy. Tak więc to, co równe, jest środkiem pomiędzy tym, co większe a tym, co mniejsze, zysk natomiast i straty są czymś większym i mniejszym w sensie przeciwnym: zysk jest większą ilością dobra, a mniejszą ilością zła, a straty - przeciwnie. Środkiem między nimi jest równość, nazywana sprawiedliwością. Tak tedy sprawiedliwość wyrównująca byłaby środkiem pomiędzy zyskiem a stratą". Proces karny stanowi jednak egzemplifikację tylko niedoskonałej sprawiedliwości proceduralnej - reguły procedowania nie są bowiem w stanie wykluczyć errores wypaczających materialną sprawiedliwość rozstrzygnięcia. Brak poprawnego rezultatu procedowania nie jest generowany świadomie błędnym działaniem organów wymiaru sprawiedliwości skazanie niewinnego lub uwolnienie od odpowiedzialności rzeczywistego sprawcy zazwyczaj jest efektem niefortunnych, sporadycznych omyłek popełnionych w procesie zdobywania informacji co do zaszłości, w związku z którą toczy się proces, i podejmowania decyzji w jego zasadniczym nurcie $^{10}$.

9 Arystoteles: Etyka nikomachejska. Księa V. Tłum. D. GromsKa. W: Idem: Dzieła wszystkie..., 1132a, s. 175.

${ }^{10}$ K. Ajdukiewicz: O sprawiedliwości. W: Idem: Język i poznanie. T. 1. Warszawa 2006, s. 37; M. BorucKa-Arctowa: Koncepcja sprawiedliwości proceduralnej i jej rola $w$ okresie przemian systemu prawa - analiza teoretyczna i funkcjonalna. W: Dynamika wartości $w$ prawie. Red. K. PAŁECKI. Kraków 1997, s. 30; H. Brighouse: Sprawiedliwość. Warszawa 2007, s. 24; J. Czaja, J. Stelmach: W stronę proceduralnej teorii sprawiedliwości. „Logos i Ethos" 1993, z. 2, s. 33; J. Rawls: Teoria sprawiedliwości. Warszawa 2009, s. 143; R. Dworkin: Biorac prawa poważnie. Warszawa 1998, s. 277; D. Lyons: Etyka i rzady prawa. Warszawa 2000, s. 131-150; M. OssowsKa: Normy moralne. Próba systematyzacji..., s. 145; C. Perelman: O sprawiedliwości..., s. 34-38; J. SKorupka: Sprawiedliwość proceduralna jako cel procesu karnego. W: Rzetelny proces karny. Księga jubileuszowa Profesor Zofii Świdy. Red. J. SKORUPKA. Warszawa 2009, s. 57-76; S. ZAвєOcKI: Sprawiedliwość proceduralna a wspótczesne trendy zwalczania przestępczości (na przykładach zmian $w$ polskiej procedurze kar- 
Ad. c. Unicestwienie wszelkich konsekwencji prawomocnego skazania motywowane potrzebą prawidłowego zrealizowania zasady sprawiedliwości komutatywnej, świadomie naruszanej na szeroką skalę w procesach określonej grupy osób, uzasadnia rehabilitację w okresach zasadniczych zmian ustrojowych. W okresach transformacji ustrojowej okazuje się bowiem, że funkcjonariusze poprzedniego reżimu, karząc za działalność opozycyjną, naruszyli zasadę nakazującą dystrybuowanie kary w zamian za zło w postaci tylko rzeczywiście wyrządzonego przestępstwa. Otóż $\mathrm{w}$ warunkach transformacji ocen aksjologicznych czyn formalnie realizujący znamiona ustawy karnej wymierzony w poprzedni ustrój, stając się zasługą, traci element materialny w postaci społecznej szkodliwości cechy czynu karalnego - uzyskując status zachowania prawnie indyferentnego ${ }^{11}$.

Przywracanie praw osobom ukaranym za działalność antyreżimową może być realizowane przez podmioty obejmujące władzę w warunkach całkowitego podważenia poprzedniego systemu politycznego, ekonomicznego i społecznego - w skrajnych przypadkach łączącego się z przerwaniem ciągłości prawnomiędzynarodowej i ukształtowaniem nowego podmiotu prawa międzynarodowego ${ }^{12}$. Akcja przywracania do grona osób niekaranych może być podejmowana również wobec tych, którzy działali przeciwko dotychczasowemu aparatowi państwowemu wymienianemu przez reformatorskie skrzydło rządzącej formacji ze względu na wypaczenia, jakich dopuścił się $\mathrm{w}$ warunkach generalnie pozytywnie ocenianego ustroju politycznego ${ }^{13}$. Stygmat osoby ukaranej może być również zdjęty z działaczy opozycyjnych walczących przeciwko poprzednio rządzącej

nej). W: Prawo i godność. Księga pamiątkowa $w$ 70. rocznicę urodzin Profesora Wojciecha Łączkowskiego. Red. S. Fundowicz, F. Rymarz, A. GomuŁowicz. Lublin 2003.

11 W. SAdURSKI: Teoria sprawiedliwości..., s. 118; K. SYCHTA: Rehabilitacja osób represjonowanych w latach 1944-1956 za działalność na rzecz niepodległego Państwa Polskiego. Katowice 2006, s. 27-47; IDEM: Aksjologiczne i dogmatyczne aspekty prawnokarnego rozrachunku z przeszłościq dokonywanego w warunkach zmiany systemu politycznego. W: Profesor Marian Cieślak - osoba - dzieło - kontynuacje. Red. W. CIEŚLAK, S. STEINBorn. Warszawa 2013, s. 465-487; Z. ZIEMBIŃsKI: O pojmowaniu sprawiedliwości..., s. 126.

12 A. Czarnota, P. Hofmański: Prawo, historia, sprawiedliwość. Polska ustawa o uznaniu za nieważne orzeczeń wydanych wobec osób represjonowanych za działalność na rzecz niepodległego bytu Państwa Polskiego a zasady rzadów prawa. W: Aktualne problemy prawa karnego i kryminologii. Red. E. PŁYWACZEWsKi. Białystok 1998, s. 137; W. DAsZKIEWICZ: Problem rehabilitacji i odszkodowań za bezprawne represje karne. PiP 1990, z. 2, s. 5; K. SYchтA: Rehabilitacja osób represjonowanych $w$ latach 1944-1956..., s. 18; IDEM: Aksjologiczne $i$ dogmatyczne aspekty prawnokarnego rozrachunku z przeszłościq dokonywanego $w$ warunkach zmiany systemu politycznego. W: Profesor Marian Cieślak - osoba..., s. 466.

13 A. Czarnota, P. Hofmański: Prawo, historia, sprawiedliwość. Polska ustawa o uznaniu za nieważne orzeczeń wydanych wobec osób represjonowanych za dziatalność na rzecz niepodległego bytu Państwa Polskiego a zasady rządów prawa. W: Aktualne problemy prawa karnego i kryminologii..., s. 137. 
formacji politycznej tracącej rządy w warunkach zachowania ciągłości prawnomiędzynarodowej państwa, któremu to upadkowi towarzyszy całkowita zmiana aksjologiczna całego systemu prawnego. Jej przejawem jest oficjalna zmiana wizji przeszłości - negatywną oceną obdarza się ustrój, w ramach którego wymiar sprawiedliwości dopuszczał się masowych nadużyć, szacunkiem zaś zaczyna otaczać się osoby prowadzące w przeszłości działalność opozycyjną ${ }^{14}$.

W niniejszych rozważaniach nazwą „rehabilitacja” zostaną objęte dwa desygnaty. Pierwszy stanowić będzie rehabilitacja sędziowska następująca ze względu na potrzebę realizacji sprawiedliwości formalnej i materialnej, sporadycznie, nieświadomie naruszonej w indywidualnych procesach. Definicja procesów rehabilitacyjnych obejmie zatem procedury nadzwyczajno-odwoławcze oraz ponowne (toczące się po uwzględnieniu nadzwyczajnego środka odwoławczego), umożliwiające uniewinnienie osoby, której prawomocnym rozstrzygnięciem nie uwolniono od odpowiedzialności karnej za niepopełnione przestępstwo w nieprawidłowo przebiegającym postępowaniu. De lege lata cechy tak sformułowanej definicji trybu przywracania osoby niewinnej do grona osób niekaranych spełniają następujące procedury:

a) postępowanie uruchomione wskutek wniesienia korzystnej dla oskarżonego kasacji od wyroków skazujących, warunkowo lub bezwarunkowo umarzających proces rzeczywiście niewinnego oskarżonego;

b) procedura zainaugurowana $\mathrm{z}$ urzędu lub $\mathrm{w}$ rezultacie złożenia wniosku zawierającego korzystne dla oskarżonego żądanie wznowienia postępowania zakończonego orzeczeniem skazującym, warunkowo lub bezwarunkowo umarzającym.

Drugi sposób definiowania instytucji przywracania do kategorii osób prawnie niewinnych traktuje ją jako rehabilitację hybrydową, tj. ustawowo-sędziowską, następującą ze względu na potrzeby zadośćuczynienia

14 Ibidem; W. DASZKIEWICZ: Problem rehabilitacji i odszkodowań za bezprawne represje karne..., s. 5; A. JöRG, E. WeIGEND: Prawo karne, zmiana systemu politycznego i obrachunek z przeszłościq $w$ Polsce i Niemczech. Próba podsumowania. W: Materiały z polsko-niemieckiej konferencji „Prawo karne a problem zmiany ustroju politycznego”. Kraków 30 wrzesień-3 październik 1996. Kraków 1996, s. 19-25; K. KaUBA: Ustawa rehabilitacyjna. SI 1995, z. 27, s. 179-181; IDEM: Przywracanie praw skazanym $w$ latach 1944-1956. EP 1994, z. 3, s. 21; J. Kochanowski: Prawo karne wobec upiorów przeszłości i wyzwań wspótczesności. SI 2000, z. 38, s. 89-103; K. SychTA: Rehabilitacja osób represjonowanych w latach 1944-1956..., s. 18; IDEM: Aksjologiczne i dogmatyczne aspekty prawnokarnego rozrachunku z przeszłościq dokonywanego w warunkach zmiany systemu politycznego. W: Profesor Marian Cieślak - osoba..., s. 465 i 467; I. Tuleya: Ustawa o uznaniu za nieważne orzeczeń wydanych wobec osób represjonowanych za działalność na rzecz niepodległego bytu Państwa Polskiego. Komentarz praktyczny. Warszawa 2013, s. 15; L. WILK: Ustawowa rehabilitacja osób represjonowanych za działalność na rzecz niepodległości Polski..., s. 63. 
względom zasady sprawiedliwości materialnej, naruszonej na masową skalę $\mathrm{w}$ procesach skazanych za aktualnie pozytywnie oceniane zachowania. Tego rodzaju desygnat nazwy de lege lata obejmuje przypadki przywracania do kategorii osób niewinnych opozycjonistów represjonowanych za działalność niepodległościową. Represjonujące ich orzeczenia unieważniła generalna deklaracja zawarta w Ustawie z dnia 23 lutego 1991 r. o uznaniu za nieważne orzeczeń wydanych wobec osób represjonowanych za działalność na rzecz niepodległego bytu Państwa Polskiego ${ }^{15}$. Klauzula unieważniająca unicestwiła zbiorowo orzeczenia wydane przez polskie organy ścigania ${ }^{16} \mathrm{i}$ wymiaru sprawiedliwości $\mathrm{i}^{17}$, polskie organy pozasądowe ${ }^{18}$

15 Ustawa z dnia 23 lutego 1991 r. o uznaniu za nieważne orzeczeń wydanych wobec osób represjonowanych za działalność na rzecz niepodległego bytu Państwa Polskiego, Dz.U. 1991, nr 34, poz. 149; Dz.U. 1993, nr 36, poz. 159; Dz.U. 1995, nr 28, poz. 143; Dz.U. 1998, nr 97, poz. 604; Dz.U. 2002, nr 240, poz. 2055.

16 O strukturze organów ścigania w okresie 1944-1956 zob. J. BorowIEC: Wojskowa prokuratura sądów doraźnych w województwie rzeszowskim maj-czerwiec 1946. W: Przestępstwa sędziów i prokuratorów w Polsce lat 1944-1956. Red. W. Kulesza, A. RzePLIŃsKi. Warszawa 2000; M. Kallas, A. LityŃsKi: Historia ustroju i prawa Polski Ludowej. Warszawa 2000; A. LITYŃsKI: „...prokuratura jest instrumentem...”. Kartka z dziejów prokuratury powszechnej Polski Ludowej. W: Wspótczesne problemy procesu karnego i wymiaru sprawiedliwości. Księa ku czci Profesora Kazimierza Marszała. Red. P. Hofmański, K. ZgrYZeK. Katowice 2003; IDEM: Historia ustroju i prawa Polski Ludowej. Warszawa 2013; IDEM: Inaczej o pierwszej dekadzie Polski Ludowej. Obraz sądów karnych. W: Z dziejów prawa Rzeczypospolitej Polskiej. Red. A. LitYŃsKI. Katowice 1991; IDEM: Ustawodawstwo karne w pierwszych latach Polski Ludowej. W: Wojna domowa czy nowa okupacja? Polska po roku 1944. Red. A. AJNENKIEL. Wrocław-Warszawa-Kraków 1998; J. MuszYński: Zasady ustrojowe sąownictwa wojskowego i prokuratury wojskowej w Polsce Ludowej. Warszawa 1964; J. TYLman: Rozwój systemu postępowania przygotowawczego w latach 1944-1956. W: ZNUŁ 1957, z. 6: Nauki Humanistyczno-Społeczne.

17 O powojennej strukturze organów wymiaru sprawiedliwości zob. J. DroHOMIRECKI: Sadownictwo wojskowe $w$ Polsce Ludowej. PiP 1971, z. 2; T. Cyprian, J. Sawicki: Siedem procesów przed Najwyższym Trybunatem Narodowym. Poznań 1962; G. JAкUBowski: Sądownictwo powszechne w latach 1944-1950. Warszawa 2002; A. GrześKowiaK: Sądy tajne w latach 1944-1956. W: Prawo okresu stalinowskiego. Zagadnienia wybrane. SI 1992, z. 22; K.M. PieKarsKa: Naruszanie zasady jawności $w$,sqadach tajnych”. W: Prawo karne $w$ okresie stalinizmu. SI 1995, z. 27; A. LITYŃski: O prawie i sq̨dach początków Polski Ludowej. Białystok 1999; A. Pyszко Prawniczy" 1946, z. 11-12; A. RzEPLIŃski: Przystosowanie ustroju sq̨downictwa do potrzeb państwa totalitarnego $w$ Polsce $w$ latach 1944-1956. W: Przestępstwa sędziów i prokuratorów $w$ Polsce lat 1944-1956..., s. 34; J. SAwICKI: O prawie sadów specjalnych. W: Wymiar sprawiedliwości w odrodzonej Polsce. 22 VII 1944-22 VII 1945. Warszawa 1945; M. TuRLejSKa: Sądy na kótkach. Głos przeciwko karze śmierci. „Przegląd Powszechny” 1988, z. 12; S. ZwouÍ́ski: Rola sqdownictwa wojennego Ludowego Wojska Polskiego w represjonowaniu Armii Krajowej. W: Armia Krajowa. Dramatyczny epilog. Red. K. Komorowski. Warszawa 1994.

${ }_{18} \mathrm{O}$ najbardziej typowym organie pozasądowym zob. M. FAJst: Komisja Specjalna na tle innych instytucji quasi-sq̨dowych. W: Przestępstwa sędziów i prokuratorów $w$ Polsce lat 1944-1956..., s. 425. 
oraz organa Polskich Sił Zbrojnych w Związku Socjalistycznych Republik Radzieckich niepodlegajace rządowi Rzeczpospolitej Polskiej ${ }^{19}$ w latach 1944-1956 za zachowania, które będąc efektem świadomego dążenia, obiektywnie sprzyjały uzyskaniu przez państwo polskie atrybutu niepodległości, czyny polegające na przeciwstawianiu się kolektywizacji wsi oraz obowiązkowym dostawom, czyny stanowiące pretekst do wszczęcia procesu z powodu działalności niepodległościowej lub kontestującej politykę rolną oraz za zachowania mające na celu uniknięcie represji grożących z tytułu działalności niepodległościowej lub skierowanej przeciwko akcjom tworzenia kołchozów i przymusowej aprowizacji. Istotą mieszanego, tj. ustawowo-sędziowskiego, charakteru rehabilitacji działaczy opozycyjnych jest następujące ipso iure unieważnienie orzeczeń represjonujących; skuteczna utrata stygmatu osoby ukaranej wymaga jednak deklaratywnej decyzji sędziowskiej, potwierdzającej wypełnienie ustawowo określonych przesłanek.

Postępowanie w przedmiocie stwierdzenia nieważności ma na celu wyeliminowanie określonej kategorii orzeczeń, należy je zatem skategoryzować jako postępowanie służące wzruszeniu decyzji procesowych. Ustalenie charakteru procedury stwierdzania nieważności wymaga uwzględnienia kryteriów odwołujących się do przedmiotu postępowania, konsekwencji orzeczenia wydanego $\mathrm{w}$ następstwie przeprowadzenia postępowania rehabilitacyjnego oraz sposobu uruchamiania procedury w przedmiocie deklaratywnego stwierdzenia nieważności. W ustawie lutowej zadeklarowano nieważność prawomocnych orzeczeń, dotyczących kwestii odpowiedzialności karnej osób represjonowanych za czyny, które opozycjoniści albo rzeczywiście popełnili, tylko wstecznie uznano je za całkowicie pozbawione społecznej szkodliwości, albo ich nie popełnili, natomiast odpowiedzialność za ich popełnienie przypisano represjonowanym za faktycznie prowadzoną działalność opozycyjną. W konsekwencji orzeczenie stwierdzające nieważność rozstrzyga w przedmiocie odpowiedzialności karnej represjonowanego, ostatecznie kończąc proces działacza opozycyjnego prawidłową decyzją rozstrzygającą o jego przedmiocie ${ }^{20}$, in effectu ustawowo uznano je więc za równoznaczne z uniewinnieniem (art. 2 ust. 1 zd. drugie

${ }^{19}$ O wojskowej służbie sprawiedliwości w ZSRR zob. W. ChMIELARCzyк: Problemy legislacyjne z zakresu prawa karnego materialnego i procesowego $w$ Polskich Sitach Zbrojnych $w$ ZSRR oraz $w$ wojsku polskim $w$ latach 1943-1945. „Wojskowy Przegląd Prawniczy” 1990, z. 4; A. LITYŃSKI: Początki stużby sprawiedliwości w Polskich Siłach Zbrojnych w ZSRR (1943). W: Dawne prawo i myśl prawnicza. Prace historycznoprawne poświęcone pamięci Wojciecha Bartla. Red. A. Malec, W. URuszczak. Kraków 1995; A. LityŃsKi: Rok 1943 $w$ Polskich Siłach Zbrojnych $w$ ZSRR: tworzenie wojskowego prawa sqdowego. W: Historia prawa - historia kultury. Liber Memorialis Vitoldo Maisel dedicatus. Red. E. BonKowsKA, H. OlszewsKi. Poznań 1994.

${ }^{20}$ G. Rejman: Kodeks karny. Część ogólna. Komentarz. Warszawa 1999, s. 120. 
ustawy lutowej). Postępowanie mające na celu unicestwienie represjonujących orzeczeń uruchamia wniosek uprawnionych podmiotów wzbogacający zamknięty już proces represjonowanego o nowy etap, ergo będący więc skargą etapową. Tym samym postępowanie rehabilitujące działaczy opozycyjnych ukształtowano jako skargowe, reformacyjne procedowanie w przedmiocie odpowiedzialności karnej uprzednio już rozstrzygniętej prawomocnym orzeczeniem. Skargowość, reformacyjność oraz prawomocność unieważnionych orzeczeń lokuje postępowanie rehabilitacyjne osób represjonowanych $\mathrm{w}$ ramach spełniających identyczne kryteria postępowań toczących się w ramach nadzwyczajnych środków odwoławczych ${ }^{21}$.

\section{Jawność procedur rehabilitacyjnych}

\section{1. § 1. Zasada jawności i jej prawnomiędzynarodowe oraz konstytucyjne umocowanie}

W najszerszym zakresie zasada jawności stanowi dyrektywę, zgodnie z którą dostęp do czynności postępowania drogą udziału w nich albo drogą ich obserwacji mają strony procesowe lub inni uczestnicy postępowania, a więc te podmioty, które bezpośrednio zainteresowane są rozstrzygnięciem o przedmiocie procesu, dostępem tym dysponuje także publiczność, na którą składają się podmioty niemające bezpośredniego interesu w rozstrzygnięciu o przedmiocie procesu, choć wynik postępowania pośrednio może być dla tej grupy znaczący ze względu na prewencję ogólną ${ }^{22}$. Zasada jawności stanowi zatem swoisty amalgamat obejmujący jawność wewnętrzną, dedykowaną bezpośrednio uczestnikom postępowania oraz jawność zewnętrzną, skierowaną do publiki i osób trzecich ${ }^{23}$.

${ }^{21}$ K. SYCHTA: Rehabilitacja osób represjonowanych $w$ latach 1944-1956..., s. 93; IDEM: Charakter prawny postępowania rehabilitacyjnego określonego ustawa z dnia 23 lutego 1991 r. RPEiS 2001, z. 4, s. 121; W. Daszkiewicz, T. NowaK, S. STAChowiak: Proces karny. Część szczególna. Poznań 1996, s. 14; T. GrzegorczyK: Kodeks postępowania karnego oraz ustawa o świadku koronnym. Kraków 2008, s. 1272.

${ }^{22}$ K. Zgryzek: Zasada jawności. W: System prawa karnego procesowego. T. 3. Cz.1: Zasady procesu karnego. Red. P. WiLIŃski. Warszawa 2014, s. 789 i 818; M. BŁAszYк, H. PALuszKIEWICZ: Jawność rozprawy głównej po nowelizacji Kodeksu postępowania karnego. W: Verba volant, scripta manent. Proces karny, prawo karne skarbowe i prawo wykroczeń po zmianach z lat 2015-2016. Księga pamiątkowa poświęcona Profesor Monice Zbrojewskiej. Red. T. GrzegorczyK, R. Olszewski. Warszawa 2017, s. 296-306; B. Wójcicka: Jawność postępowania sądowego $w$ polskim procesie karnym. Łódź 1989, s. 7.

${ }_{23}$ Wyrok Trybunału Konstytucyjnego z dnia 11 czerwca 2002 r., SK 5/02, Dz.U. 2002, nr 84, poz. 763. Zob. też M. LiPCZYŃsKa: Stanowisko oskarżonego w procesie karnym Polski Ludowej. Warszawa 1956, s. 130-131; A. KafTAL: Jawność postępowania karnego w świetle 
Oba aspekty zasady jawności są fundowane na prawnomiędzynarodowych i konstytucyjnych przepisach, eksplikujących jawność procesu karnego. Prawnomiędzynarodową podstawę tej zasady procesu karnego statuuje art. 10 Powszechnej Deklaracji Praw Człowieka z dnia 10 grudnia 1948 r., a także art. 14 ust. 1 i ust. 3 Międzynarodowego Paktu Praw Obywatelskich i Politycznych ${ }^{24}$ z dnia 19 grudnia 1966 r. Zasadę jawności wyraża również art. 6 ust. 1 Konwencji o Ochronie Praw Człowieka i Podstawowych Wolności ${ }^{25}$ z dnia 4 listopada 1950 r. oraz art. 47 Karty Praw Podstawowych Unii Europejskiej ${ }^{26}$.

Pierwszy akt międzynarodowy traktuje prawo do jawności jako prawo przyrodzone i istniejące samoistnie, będące w Deklaracji jedynie przedmiotem doprecyzowania, kodyfikacji, uznania, poparcia, poszanowania i zachęty do przestrzegania. Zgodnie z art. 10 Deklaracji zasada ta stanowi element fundamentalnego prawa do sprawiedliwego, niezależnego i bezstronnego sądu. Istotą prawa do sądu jest przysługujące każdemu człowiekowi, na warunkach całkowitej równości, prawo do tego, by przy rozstrzyganiu o jego prawach i zobowiązaniach lub o zasadności wysuwanego przeciwko niemu oskarżenia o popełnienie przestępstwa zostać wysłuchanym sprawiedliwie i jawnie przez niezależny i bezstronny sąd.

Zasadę jawności jako składową prawa do sądu o niemal identycznym zakresie jak w Deklaracji ONZ konstytuuje Międzynarodowy Pakt Praw Obywatelskich i Politycznych. Zgodnie z art. 14 ust. 1 MPPOiP standardem w zakresie międzynarodowej ochrony praw człowieka jest prawo każdego do sprawiedliwego i publicznego rozpatrzenia sprawy przez właściwy, niezależny i bezstronny sąd, ustanowiony przez ustawę przy orzekaniu co do zasadności oskarżenia przeciw niemu w sprawach karnych ${ }^{27}$. Art. 14 ust. 3 MPPOiP normuje zasadę jawności wewnętrznej, gwarantując każdemu

nowego kodeksu postępowania karnego. NP 1969, z. 11-12, s. 1640; B. WóJCicKA: Jawność postępowania sq̨dowego $w$ polskim procesie karnym..., s. 9; J. Tylman: Postępowanie przed sq̨dem pierwszej instancji. Warszawa 1999, s. 33; M. LeciaK: Wyłaczenie jawności rozprawy z uwagi na ochronę tajemnicy państwowej w procesie karnym. PiP 2007, z. 2, s. 59.

${ }^{24}$ Międzynarodowy Pakt Praw Obywatelskich i Politycznych z dnia 19 grudnia 1966, ratyfikowany oświadczeniem rządowym z dnia 23 kwietnia 1977 r., Dz.U. 1977, nr 38, poz. 168 .

${ }^{25}$ Konwencja o Ochronie Praw Człowieka i Podstawowych Wolności z dnia 4 listopada 1950 r., Dz.U. 1993, nr 61, poz. 284.

${ }^{26}$ Karta Praw Podstawowych Unii Europejskiej (2007/C 303/01) jest częścią Traktatu z Lizbony zmieniającego Traktat o Unii Europejskiej i Traktat ustanawiający Wspólnotę Europejską, sporządzonego w Lizbonie dnia 13 grudnia 2007 r., Dz.U. 2009, nr 203, poz. 1569 , ze sprost.

27 J. SKorUPKa: Prawnomiędzynarodowe i konstytucyjne podstawy jawności procesu karnego. W: Jawność procesu karnego. Red. J. SKorupKa. Warszawa 2012, s. 43; K. ZgrYzeK: Zasada jawności. W: System prawa karnego procesowego. T. 3. Cz. 1..., s. 799. 
oskarżonemu o popełnienie przestępstwa określone uprawnienia podlegające realizacji przed procedującym jawnie zewnętrznie, sprawiedliwie niezależnym i bezstronnym sądem. W ramach tak wystandaryzowanej procedury jawność skierowana do jej wnętrza obejmuje: 1) otrzymywanie niezwłocznie szczegółowej informacji w języku zrozumiałym dla oskarżonego o rodzaju i przyczynie oskarżenia; 2) dysponowanie odpowiednim czasem i możliwościami w celu przygotowania obrony i porozumienia się z obrońca przez siebie wybranym; 3) przeprowadzenie rozprawy bez nieuzasadnionej zwłoki; 4) obecność na rozprawie, możliwość bronienia się osobiście lub przez obrońcę przez siebie wybranego, otrzymanie informacji, jeżeli nie posiada obrońcy, o istnieniu powyższego prawa oraz posiadanie obrońcy wyznaczonego dla oskarżonego w każdym przypadku, gdy wymagają tego interesy wymiaru sprawiedliwości, bez ponoszenia kosztów obrony w przypadkach, kiedy oskarżony nie posiada dostatecznych środków na ich pokrycie; 5) przesłuchanie lub spowodowanie przesłuchania świadków oskarżenia i zapewnienie obecności oraz przesłuchania świadków obrony na tych samych warunkach, co świadków oskarżenia; 6) korzystanie z bezpłatnej pomocy tłumacza, jeżeli oskarżony nie rozumie lub nie mówi językiem używanym w sądzie oraz 7) nieprzymuszanie do zeznawania przeciwko sobie lub do przyznania się do winy.

Równie fundamentalny wymiar nadaje zasadzie prawa do sądu, obejmującego swoim zakresem prawo do publicznego rozpoznania sprawy, art. 6 EKPC. Konwencyjny standard w zakresie szeroko ujętego prawa do sądu konstruuje przepis zawierający ogólną formułę prawa (ust. 1) oraz szereg szczegółowych gwarancji dedykowanych wyłącznie postępowaniu karnemu (ust. 2 i 3). Ogólna formuła prawa do sprawiedliwego i publicznego rozpatrzenia sprawy obejmuje dalsze składowe, gwarantujące: 1) rozpatrzenie sprawy w rozsądnym terminie; 2) niezawisłość i bezstronność sądu ustanowionego ustawą oraz 3) jawność postępowania ${ }^{28}$.

28 Ogólne prawo znajduje na gruncie procedur karnych uszczegółowienie, odnoszące się także do treści zasady jawności. Wewnątrz procesu karnego zasadę prawa do sądu konstytuuje bowiem dodatkowo: 1) domniemanie niewinności; 2) prawo do informacji o oskarżeniu; 3) prawo do odpowiedniego czasu i możliwości przygotowania się do obrony; 4) prawo do bronienia się osobiście lub przez ustanowionego przez oskarżonego obrońcę; 5) prawo do bezpłatnego korzystania z obrońcy wyznaczonego z urzędu; 6) prawo do przesłuchania lub spowodowania przesłuchania świadków oraz 7) prawo do korzystania z bezpłatnej pomocy tłumacza. Zob. P. Hofmański, A. Wróbel: Prawo do rzetelnego procesu sądowego. W: Konwencja o Ochronie Praw Człowieka i Podstawowych Wolności. T. 1: Komentarz do art. 1-18. Red. L. GARLICKI. Warszawa 2010, s. 261; M.A. NowicKI: Wokót Konwencji Europejskiej. Komentarz do Europejskiej Konwencji Praw Człowieka. Warszawa 2010, s. 509; J. SKORUPKA: Prawnomiędzynarodowe i konstytucyjne podstawy jawności procesu karnego. W: Jawność procesu karnego..., s. 46; K. ZgrYzeK: Zasada jawności. W: System prawa karnego procesowego. T. 3. Cz. 1..., s. 797. 
Zawartą w art. 6 EKPC ogólną formułę prawa do sądu mieszczącą jawność postępowania niemal dubluje art. 47 Karty Praw Podstawowych Unii Europejskiej; gwarancją dotyczącą wymiaru sprawiedliwości w Unii Europejskiej zabezpieczono każdego w zakresie sprawiedliwego i jawnego rozpatrzenia sprawy przez niezawisły i bezstronny sąd ustanowiony uprzednio na mocy ustawy ${ }^{29}$.

Wzorem rozwiązań prawnomiędzynarodowych w polskim wewnątrzkrajowym porządku prawnym zasada jawnego rozpoznawania spraw przez sądy stanowi komponent prawa do sądu, ujmowanego także jako prawo do wymiaru sprawiedliwości ${ }^{30}$. Konstytucyjne umocowanie prawa do sądu zawiera art. 45 Ustawy Zasadniczej, statuujący kolejno prawo do rozpatrzenia sprawy przez sąd, atrybuty organu sądowego (właściwy, niezależny, bezstronny oraz niezawisły) oraz standardy proceduralne (sprawiedliwość, jawność, rozpoznanie sprawy bez nieuzasadnionej zwłoki). Zasadę prawa do sądu dopełniają: konstytucyjnie gwarantowany zakaz zamykania drogi sądowej, zabezpieczający uprawnienie do wszczęcia lub kontynuowania postępowania sądowego (art. 77 ust. 2 Konstytucji $\mathrm{RP}$ ), oraz konstytucyjnie umocowane prawo do złożenia środka odwoławczego (art. 78 oraz 176 ust. 1 Konstytucji RP) ${ }^{31}$.

Ogół prawnomiędzynarodowych i konstytucyjnych fundamentów zasady jawnego rozpoznawania spraw przez sądy kategoryzuje jawność zewnętrzną i wewnętrzną jako komponenty zasady prawa do sądu posiadającego określone atrybuty i orzekającego w odpowiednio wystandaryzowanej procedurze. Sprzężenie zasady prawa do sądu z wymogami, jakie powinien posiadać organ wymiaru sprawiedliwości, oraz kryteriami, jakim powinno odpowiadać rozpoznanie sprawy, implikuje oznaczenie wszystkich składowych prawa do sądu jako ogólnego prawa do rzetelnego procesu sądowego (fair trial) ${ }^{32}$. Ukonstytuowany normami prawnomię-

${ }^{29}$ M.A. NowickI: Wokót Konwencji Europejskiej. Komentarz..., s. 289; K. ZGrYZEK: Zasada jawności. W: System prawa karnego procesowego. T. 3. Cz. 1..., s. 798.

30 J. SKORUPKA: Prawnomiędzynarodowe i konstytucyjne podstawy jawności procesu karnego. W: Jawność procesu karnego..., s. 489.

31 Z. CzeszejKo-Sochacki: Prawo do sądu w świetle Konstytucji Rzeczypospolitej Polskiej (Ogólna charakterystyka). PiP 1997, z. 11-12, s. 97; IDEM: Prawo do sądu w świetle Konstytucji Rzeczypospolitej Polskiej. Prok. i Pr. 1997, z. 11-12, s. 11; L. Garlicki: Prawo do sądu (rozważania de lege fundamentale ferenda). AUMCS 1990, z. 37, s. 61; A. KuBIAK: Konstytucyjna zasada prawa do sądu $w$ świetle orzecznictwa Trybunatu Konstytucyjnego. Łódź 2006, s. 55; J. SKORUPKa: Prawnomiędzynarodowe i konstytucyjne podstawy jawności procesu karnego. W: Jawność procesu karnego..., s. 88; P. WiLIŃsKi: Konstytucyjny standard prawa do sadu a proces karny. W: Węzłowe problemy procesu karnego. Red. P. Hofmański. Warszawa 2010, s. 211-221; K. ZGRYZEK: Zasada jawności. W: System prawa karnego procesowego. T. 3. Cz. 1 ..., s. 793.

${ }_{32}$ M. CIEślaK: Podstawowe prawa i wolności w Europejskiej Konwencji Praw Człowieka na tle orzecznictwa Europejskiego Trybunału Praw Człowieka w okresie 1988-1992. Warszawa 
dzynarodowymi i wewnątrzkrajowymi wzorzec rzetelnego procesu może być kwalifikowany jako element wyznaczający model postępowania syntetyzujący ogół innych zasad procesowych, łącznie określających metodę procedowania w kwestii odpowiedzialności karnej ${ }^{33}$, jako pewna kategoria ogólna, stanowiąca zbiór zasad, norm lub dyrektyw wykształcających jej treśćc ${ }^{34}$ czy też cecha sine qua non procesu rzetelnego ${ }^{35}$. En tout eas, zarówno wśród komponentów syntetyzowanych jako metoda procedowania, jak i w zestawie powtarzających się elementów kwalifikowanych jako poddyrektywy wyznaczające zawartość treściową zasady rzetelnego procesu zawsze lokuje się jawne zewnętrznie i wewnętrznie rozpoznawanie spraw przez sądy.

1995, s. 56; W. JASIŃsKI: Jawność postępowania jako warunek rzetelnego procesu karnego $w$ orzecznictwie Europejskiego Trybunatu Praw Człowieka. W: System wymiaru sprawiedliwości a media. Red. C. Kulesza. Białystok 2009, s. 113; J. SkoruPKa: Prawnomiędzynarodowe i konstytucyjne podstawy jawności procesu karnego. W: Jawność procesu karnego..., s. 54; M.P. WęDrYChOwski: Prawo do „uczciwej rozprawy” $w$ Europejskiej Konwencji Praw Człowieka. PS 1991, z. 5-6, s. 62.

${ }^{33}$ P. WiLIŃski: Pojęcie rzetelnego procesu karnego. W: Skargowy model procesu. Księga ofiarowana Profesorowi Stanisławowi Stachowiakowi. Red. A. GERECKA-ŻoŁYŃsKA, P. Górecki, H. Paluszkiewicz, P. WiLiński. Warszawa 2008, s. 404; IDEm: Pojęcie rzetelnego procesu karnego. W: Rzetelny proces karny $w$ orzecznictwie sądów polskich i międzynarodowych. Red. P. WiLIŃski. Warszawa 2009, s. 24 i nast.; IDEM: Współczesne dyskusje o zasadach procesu karnego. W: System Prawa Karnego Procesowego. Zasady procesu karnego. T. 3. Cz. 1..., s. 258; A. MurzYNowski: Istota i zasady procesu karnego. Warszawa 1976, s. 55; I. NowIкошsкI: Uwagi o zasadzie rzetelnego procesu karnego (kwestie wybrane). W: Rzetelny proces karny. Księga jubileuszowa Profesor Zofii Świdy..., s. 56; E. SKRĘTOwicz: Z problematyki rzetelnego procesu karnego. W: Rzetelny proces karny. Ksiega jubileuszowa Profesor Zofii Świdy..., s. 21; M. RogaCKA-RZEWNICKA: Znaczenie niepisanych regut postępowania dla tworzenia podstaw rzetelnego procesu karnego. W: Rzetelny proces karny. Ksiega jubileuszowa Profesor Zofii Świdy..., s. 97.

${ }^{34}$ Zasadę rzetelnego procesu jako zbiór złożony z określonych komponentów tworzących jej treść - różnie postrzegając zestaw poszczególnych poddyrektyw łącznie składających się na zasadę rzetelnego procesu - definiują: W. DAszkiEwicz: Prawo karne procesowe. Zagadnienia ogólne. T. 1. Poznań 1999, s. 70; P. HofMAńsKi: Europejska Konwencja Praw Człowieka $i$ jej znaczenie dla prawa karnego materialnego, procesowego i wykonawczego. Białystok 1993, s. 269; K. Marszat: Proces karny. Zagadnienia ogólne. Katowice 2012, s. 51; J. Pradel: Rzetelny proces karny w europejskim prawie karnym. Prok. i Pr. 1996, z. 9, s. 7 i nast.; A. REDELbACH: Zasada rzetelności postępowania $w$ rozstrzygnięciach organów strasburskich. RPEiS 1997, z. 2, s. 26.

35 Brak wyodrębnienia zasady rzetelnego procesu i posługiwanie się określeniem rzetelnego albo uczciwego procesu, opisywanego poprzez określone cechy przypominające zestaw komponentów składających się na zasadę rzetelnego procesu karnego, jest charakterystyczny dla poglądów następujących Autorów: M. Barącz: Pojęcie i cechy „uczciwego procesu karnego". PiP 1991, z. 12, s. 75; M. PŁACHTA: Prawnomiędzynarodowe i konstytucyjne podstawy ochrony praw oskarżonego $w$ procesie karnym. GSP 1999, t. 4, s. 22; A. WĄSEK: Rzetelny proces karny. „Kościół i Prawo” 1998, t. 13, s. 190. 


\section{2. § 2. Zasada jawności wewnętrznej}

Kompleksowy opis zasady jawności wewnętrznej wymaga uwzględnienia jej podmiotowego i przedmiotowego zakresu, tj. wskazania objętych jej działaniem uczestników procesu oraz określenia ich uprawnień gwarantowanych treścią zasady. Jak już wspomniano, podmiotowy zakres zasady jawności wewnętrznej pozwala objąć wynikającymi z niej gwarancjami wszystkie podmioty mające prawny interes $\mathrm{w}$ korzystnym dla siebie rozstrzygnięciu zasadniczej i incydentalnych kwestii w postępowaniu karnym (tj. strony, quasi-strony, innych prawnie zainteresowanych) oraz działających w ich imieniu przedstawicieli procesowych (obrońców, pełnomocników i przedstawicieli ustawowych) ${ }^{36}$. Wykaz uprawnień osób prawnie zainteresowanych, wynikających z zasady jawności wewnętrznej $\mathrm{w}$ jej przedmiotowym aspekcie, obejmuje możliwość osobistego wzięcia udziału w postępowaniu modelowym lub wzbogaconym o kolejne etapy oraz dopuszczalność efektywnego realizowania uprawnień w toczącym się procesie. Vide supra, standardy prawnomiędzynarodowe eksplikują jawność jako obecność w trakcie postępowania i sprzężone z nim uprawnienie do bycia wysłuchanym, przedstawiania swoich racji oraz zgłaszania wniosków dowodowych. Aktywny udział w dążeniu do uzyskania korzystnego rozstrzygnięcia jest zatem możliwy tylko wówczas, gdy czynności procesowe są otwarte, a ponadto strony, w celu pozyskania informacji warunkujących dynamiczny udział w czynnościach, dysponują dostępem do materiału dowodowego ${ }^{37}$.

$\mathrm{Z}$ perspektywy celu procesu niewątpliwie najważniejszy jest dostęp stron do ogółu rozpraw odbywających się in casu, tj. rozprawy głównej, apelacyjnej i kasacyjnej. Prawdą jest, że to rozprawa główna stanowi najważniejszy odcinek drogi procesu, jest bowiem centralnym etapem stadium jurysdykcyjnego $\mathrm{w}$ modelowym pierwszoinstancyjnym przebiegu, na forum którego dokonuje się kontradyktoryjne rozpoznanie oraz rozstrzygnięcie dotyczące zasadniczego przedmiotu procesu, zaś strony mogą w najpełniejszy sposób realizować uprawnienia implikowane zasadami bezpośredniości, kontradyktoryjności, równości broni, ustności, prawa do obrony oraz szeroko interpretowanej zasady rzetelności ${ }^{38}$. Dopiero jednak otwarcie ogółu rozpraw odbywających się w modelowym i wzbogaconym

36 W. JAsIŃsKi: Jawność wewnętrzna postępowania sądowego. W: Jawność procesu karnego..., s. 214.

${ }^{37}$ M. CIEŚlaK: Polska procedura karna. Podstawowe założenia teoretyczne. W: IDEM: Dzieła wybrane. T. 2. Red. S. Waltoś przy współpracy M. Rusinka i S. STEInBorna. Kraków 2011, s. 210.

${ }^{38}$ Ibidem, s. 51; W. JasIŃsKI: Jawność wewnętrzna postępowania sadowego. W: Jawność procesu karnego..., s. 220; S. KALINowsKi: Rozprawa główna w polskim procesie karnym. 
toku postępowania gwarantuje stronom możliwość prowadzenia sporu w przedmiocie odpowiedzialności karnej w trakcie całego procesu karnego za pomocą wszelkich środków służących walce o rozstrzygnięcie korzystne dla swoich prawnych interesów, tj. aktywnego uczestnictwa w postępowaniu dowodowym, którego wyniki są relewantne dla rozstrzygnięcia zapadającego $\mathrm{w}$ zasadniczym przedmiocie procesu, wykorzystania ofensywnych i defensywnych środków służących uzyskaniu korzystnego dla siebie rozstrzygnięcia sytuacji konfliktowej, kontynuowania sporu przed sądem odwoławczym po podważeniu nieakceptowalnej decyzji sądowego stosowania prawa, w dalszej zaś perspektywie - po zainicjowaniu procedury nadzwyczajno-odwoławczej, stwarzającej szansę na uchylenie niekorzystnego rozstrzygnięcia - powrotu do merytorycznego sporu dotyczącego konfliktu wygenerowanego popełnieniem przestępstwa. Także orzecznictwo Europejskiego Trybunału Praw Człowieka bardzo szeroko wyznacza zakres obowiązywania zasady rzetelnego procesu, obejmującej jawne wewnętrznie rozpoznawania spraw ${ }^{39}$. Judykaty trybunalskie pozwalają przyjąć, że bez względu na stopień skomplikowania sprawy karnej ${ }^{40}$ prawo do rzetelnego procesu przysługuje nie tylko w stadium sądowym, ale także w postępowaniu przygotowawczym ${ }^{41}$, odwoławczym ${ }^{42}$, kasacyjnym $^{43}$ i wykonawczym oraz $\mathrm{w}$ postępowaniach stanowiących dalsze etapy odpowiedniego procesu karnego, których skutki mogą mieć decydujące znaczenie dla oskarżonego ${ }^{44}$. Gwarancje rzetelnego procesu nie obejmu-

Warszawa 1975, s. 5; R. KoPER: Jawność rozprawy głównej a ochrona prawa do prywatności $w$ procesie karnym. Warszawa 2010, s. 50-53.

39 W. JASIŃSKI: Jawność postępowania jako warunek rzetelnego procesu karnego..., s. 116; J. SKorUPKA: Prawnomiędzynarodowe i konstytucyjne podstawy jawności procesu karnego. W: Jawność procesu karnego..., s. 57.

${ }_{40}$ Wyrok ETPCz z dnia 6 maja 1985 r. w sprawie 8658/79 Bönisch p. Austrii, LEX nr 81003.

${ }^{41}$ Wyrok ETPCz z dnia 24 listopada 1993 r. w sprawie 13972/88 Imbrioscia p. Szwajcarii, LEX nr 80549. O obowiązywaniu zasady jawności w postępowaniu przygotowawczym w polskim porządku prawnym zob. C. KulEsza: Zasada jawności a prawo do obrony. W: System wymiaru sprawiedliwości a media..., s. 37; R Ponikowski: Granice jawności wewnętrznej i zewnętrznej przygotowawczego stadium postępowania karnego. W: Jawność procesu karnego..., s. 130-210; K. ZGRYZEK: Zasada jawności. W: System prawa karnego procesowego. T. 3. Cz. 1..., s. 801.

${ }^{42}$ Wyrok ETPCz z dnia 17 stycznia 1970 r. w sprawie 2689/65 Delcourt p. Belgii, LEX nr 80778; wyrok ETPCz z dnia 26 maja 1988 r. w sprawie 10563/83 Ekbatani p. Szwecji, LEX nr 81055.

${ }^{43}$ Wyrok ETPCz z dnia 26 lipca 2002 r. w sprawie 32911 i 35237/97 Meftah i in. p. Francji, LEX nr 75488.

${ }^{44}$ Wyrok ETPCz z dnia 25 lutego 2000 r. w sprawie 29357/95 Gast i Popp p. Niemcom, LEX nr 76905. Zob. też D. KALA: Jawność postępowania o wydanie wyroku łącznego. W: Rzetelny proces karny. Księga jubileuszowa Profesor Zofii Świdy..., s. 654. 
ją natomiast postępowań incydentalnych, np. postępowań toczących się $\mathrm{w}$ przedmiocie tymczasowego aresztowania ${ }^{45}, \mathrm{w}$ sprawie wyłączenia sędziego $^{46}$ czy też w przedmiocie zastosowania amnestii ${ }^{47}$.

Dla rehabilitowanego i jego obrońcy, dążących do odzyskania statusu osoby niekaranej w procedurze rehabilitacji sędziowskiej, najistotniejsze jest otwarcie forów procedowania w przedmiocie zasadności nadzwyczajnego środka odwoławczego, dopiero bowiem obalenie wyroku stwierdzającego winę rzekomego sprawcy warunkuje dalsze starania o prawidłowe rozstrzygnięcie kwestii odpowiedzialności karnej oskarżonego. Dla oskarżonego znajdującego się $\mathrm{w}$ procedurze rehabilitacji powinny być dostępne także fora będące miejscem ponownego rozpoznawania kwestii odpowiedzialności karnej. Udziału $\mathrm{w}$ forach sądowych odbywających się celem rozstrzygnięcia o zasadniczym przedmiocie procesu nie różnicuje bowiem to, czy kwestia odpowiedzialności karnej jest analizowana przed sądem in meriti orzekającym $\mathrm{w}$ ramach modelowego toku postępowania, czy też analizuje ją sąd procedujący w postępowaniu ponownym, odbywającym się we wzbogaconym toku procesu. Ogół forów badających sporną kwestię odpowiedzialności karnej musi bowiem przebiegać w uczciwej i rzetelnej, ergo jawnej procedurze. Otwarcie forów orzekania w procedurze nakierowanej na odzyskanie statusu osoby niekaranej jest warunkiem tego, by dążenie do uniewinnienia było realizowane jawnie, tj. w warunkach obowiązywania zasad procesowych najistotniejszych z perspektywy walki o korzystne rozstrzygnięcie o zasadniczym przedmiocie procesu.

Ukształtowanie wewnętrznej jawności procedur rehabilitacyjnych jest warunkowane dwoma czynnikami - pierwszy element, wyznaczający katalog osób uprawnionych lub zobowiązanych do uczestnictwa w postępowaniu prowadzącym do odzyskania statusu osoby niewinnej, stanowi forum rozstrzygania najpierw o zasadności nadzwyczajnego środka odwoławczego ukierunkowanego korzystnie dla skazanego, później zaś o uwolnieniu od odpowiedzialności karnej za przestępstwo przypisane kwestionowanym orzeczeniem. Drugim elementem decydującym o przedmiotowym i podmiotowym ukształtowaniu zakresu zasady jawności wewnętrznej procedury rehabilitacyjnej jest instancja, w której sąd ostatecznie unicestwia skutki prawomocnego przypisania odpowiedzialności karnej, uniewinniając rehabilitowanego. De lege lata decyzja o przywróceniu statusu osoby niekaranej może zostać podjęta zarówno na rozprawie,

${ }^{45}$ Wyrok ETPCz z dnia 27 czerwca 1968 r. w sprawie 1936/63 Neumeister p. Austrii, LEX nr 80785.

${ }^{46}$ Decyzja ETPCz z dnia 11 grudnia 2003 r. w sprawie 58751/00 Schreiber i Boetsch p. Francji, LEX nr 285795.

${ }^{47}$ Decyzja ETPCz z dnia 13 maja 2003 r. w sprawie 59290/00 Montcornet p. Francji, LEX nr 285535. 
jak i na posiedzeniu odbywających się przed sądem uprawnionym do rozpoznania zasadności środka uruchomionego dla zrehabilitowania oskarżonego bądź też przed ponownie orzekającymi sądami I lub II instancji.

\section{3. § 3. Wewnętrzna jawność postępowań rehabilitacyjnych odbywających się w trybie kasacji}

\subsubsection{Fora odbywające się w procedurze rehabilitacyjnej}

Decyzja o przywróceniu statusu boni viri, podejmowana wskutek kasacji wniesionej na korzyść rehabilitowanego, może zostać podjęta w kil$\mathrm{ku}$ różnych konfiguracjach procesowych, obejmujących procedowanie w przedmiocie zasadności środka służącego rehabilitacji oraz toczące się jednocześnie lub następczo postępowanie uniewinniające. Ostateczny powrót do grona osób z prawnego punktu widzenia niewinnych jest możliwy wskutek decyzji zapadających na następujących forach sądów różnych szczebli:

a) rozprawie przed Sądem Najwyższym obejmującej jednoczesne rozpoznanie kwestii zasadności kasacji oraz uwolnienie osoby rehabilitowanej skazanej w oczywiście niesłuszny sposób;

b) rozprawie w przedmiocie zasadności nadzwyczajnego środka odwoławczego toczącej się przed Sądem Najwyższym oraz ponownym procedowaniu dotyczacym uniewinnienia od prawomocnie przypisanego przestępstwa, odbywającym się po uchyleniu wyroku i następczym przekazaniu do powtórnego rozpoznania kwestii odpowiedzialności karnej rehabilitowanego przez sąd odwoławczy (gdy uchybienie stanowiące podstawę kasacji obciąża wyłącznie wyrok sądu II instancji) lub przez sąd in meriti (gdy brak uniewinnienia rehabilitowanego był wynikiem błędów sądu pierwszoinstancyjnego, niedostrzeżonych następnie w postępowaniu apelacyjnym, a więc sąd odwoławczy nie dokonał korektury uchybień obciążających orzeczenie pierwszoinstancyjne, mimo że w ogóle mógł i powinien był zmienić albo uchylić zakwestionowane orzeczenie w związku z rozpoznaniem środka odwoławczego $)^{48}$;

${ }^{48}$ M. BIŁYJ, A. MuRzYNowsKI: Wznowienie postępowania karnego w PRL w świetle prawa i praktyki. Warszawa 1980, s. 138; P. HofmańsкI: Orzeczenie sadu kasacyjnego. W: Aktualne problemy prawa i procesu karnego. Ksiega ofiarowana profesorowi Janowi Grajewskiemu. Red. M. PŁachta. GSP 2003, t. 11, s. 351; A. Kaftal: Kontrola prawomocnych orzeczeń $w$ polskim procesie karnym. Warszawa 1971, s. 205-207; S. ŚLIwiśski: Wznowienie postępowania karnego w prawie polskim na tle porównawczym. Warszawa 1957, s. 162-163. 
c) posiedzeniu Sądu Najwyższego obejmującym jednoczesne badanie kwestii zasadności kasacji - zakończone, niewymagającym prowadzenia skomplikowanej wykładni prawa czy rozstrzygania spornych w doktrynie lub orzecznictwie problemów prawnych, których wyjaśnieniu służyć musiałoby przeprowadzenie $\mathrm{w}$ tej kwestii rozważań $\mathrm{w}$ toku kontradyktoryjnej rozprawy ${ }^{49}$, zakwalifikowaniem podniesionych w skardze uchybień kwestionujących skazanie jako ewidentnych - oraz następcze uwolnienie skazanego od odpowiedzialności za przestępstwo inkryminowane rehabilitowanemu w sposób oczywiście niesłuszny ${ }^{50}$.

\subsubsection{Dostępność rozpraw rehabilitacyjnych dla oskarżonego}

W najszerszym zakresie procedura rehabilitacyjna pozostaje dostępna dla najbardziej zainteresowanych rozstrzygnięciem $\mathrm{w}$ przedmiocie postępowania zmierzającego do unicestwienia na rozprawie statusu osoby skazanej, tj. oskarżonego i jego obrońcy. Wszystkie rozprawy przed Sądem Najwyższym - lege non distinguente obejmujące wyłącznie procedowanie w przedmiocie zasadności kasacji lub postępowanie badające zasadność nadzwyczajnego środka odwoławczego, połączone z postępowaniem uniewinniającym rehabilitowanego skazanego w oczywiście nieprawidłowy sposób - pozostają dostępne dla przywracanego do kategorii osób niekaranych. Na podstawie art. $450 \S 2$ k.p.k. w zw. z art. 518 k.p.k. udział oskarżonego w rozprawie rehabilitacyjnej jest fakultatywny.

Decyzję o rzeczywistym i aktywnym uczestnictwie pozostawiono więc niemal wyłącznie w gestii samego zainteresowanego, swobodę oskarżonego w zakresie decydowania o udziale ograniczono obustronnie w dwóch przypadkach - primo, uniemożliwiając fakultatywny udział oskarżonego chcącego stawić się na rozprawę kasacyjną, secundo, tworząc podstawy do zobowiązania oskarżonego do stawiennictwa na rozprawę rehabilitacyjną. Ograniczenie uprawnień oskarżonego dotyczy przypadków, gdy ten jest z jakichkolwiek powodów pozbawiony wolności - mimo sygnalizowanej woli stawiennictwa, oskarżonego nie sprowadza się wówczas na rozprawę, z wyjątkiem gdy o dopuszczeniu rehabilitowanego pozbawionego wolności zdecyduje Prezes Sądu Najwyższego lub Sąd Najwyższy

49 Wyrok Sądu Najwyższego z dnia 15 grudnia 2000 r., II KKN 142/98, OSNKW 2001, z. 1-2, poz. 12; wyrok Sądu Najwyższego z dnia 26 stycznia 2001 r., IV KKN 578/00, OSNKW 2001, z. 5-6, poz. 49.

${ }^{50}$ L. PAPRZYCKI: Oczywista bezzasadność i oczywista zasadność kasacji. W: Wspótczesne problemy procesu karnego i wymiaru sprawiedliwości. Księga pamiątkowa ku czci Profesora Kazimierza Marszata..., s. 314. 
(art. $535 \S 2$ k.p.k.). Także zobowiązanie do stawiennictwa rehabilitowanego niemającego takiego obowiązku ex lege pozostawiono w kognicji Prezesa Sądu Najwyższego lub Sądu Najwyższego. Oba te podmioty mogą uznać potrzebę stawiennictwa osoby pozbawionej wolności lub niezbędną obecność na rozprawie kasacyjnej walczącego o powrót do grona osób niekaranych w warunkach wolnościowych - jak się wydaje - zwłaszcza wówczas, gdy Sąd Najwyższy jednocześnie z kwestią zasadności kasacji uwalnia oskarżonego od zarzucanego mu czynu, ostatecznie już na tym etapie procedury rehabilitacyjnej przywracając go do grona osób niekaranych $^{51}$. Nałożenie obowiązku stawiennictwa ex institutio decyzją Prezesa Sądu Najwyższego lub Sądu Najwyższego jest natomiast zbędne, gdy procedura rehabilitacyjna przed Sądem Najwyższym ogranicza się wyłącznie do badania zasadności nadzwyczajnego środka odwoławczego, przedmiot analiz Sądu Najwyższego stanowić bowiem będą kwestie prawne wymagające wiedzy fachowej. Osobiste obowiązkowe uczestnictwo oskarżonego w rozprawie kasacyjnej nie ma wówczas tak fundamentalnego znaczenia, jak jego obecność w trakcie prowadzenia sporu co do ustaleń faktycznych, wymagających oceny lub przeprowadzenia dowodów ${ }^{52}$. Stricte prawny charakter zagadnień badanych przez Sąd Najwyższy pozwala przyjąć, że salve veritate obecność oskarżonego nie wniosłaby do sprawy niczego nowego ponad to, co zostało przedstawione na piśmie lub znajduje się $\mathrm{w}$ aktach sprawy ${ }^{53}$.

Otwarte dla rehabilitowanego pozostaje również powtórne procedowanie na rozprawie sądu odwoławczego, tym razem mające finalnie potwierdzić jego niewinność. Aktywna walka o unicestwienie skutków uprzedniego skazania - której elementem jest udział w powtórnej rozprawie apelacyjnej - stanowi bowiem tylko uprawnienie zainteresowanego uniewinnieniem (art. 450 § 2 k.p.k.). Fakultatywny charakter decyzji o aktywnej lub pasywnej postawie $\mathrm{w}$ rozprawie przed sądem odwoławczym orzekającym w przedmiocie ostatecznego uwolnienia od odpowiedzialności za zarzucone rehabilitowanemu przestępstwo podlega ograniczeniom zastosowalnym w razie, gdy rehabilitowany jest pozbawiony wolności, swoboda decyzji o uczestnictwie rehabilitowanego w rozprawie apelacyj-

51 W. Jasiński: Jawność wewnętrzna postępowania sq̨dowego. W: Jawność procesu karnego..., s. 266; M.J. URBANIAK: Rozpoznawanie spraw pod nieobecność oskarżonego $w$ polskim procesie karnym. Poznań-Kalisz 2003, s. 187.

${ }^{52}$ Wyrok ETPCz z dnia 19 grudnia 1989 r. w sprawie 9783/82 Kamasinski p. Austrii, LEX nr 81088.

53 Wyrok ETPCz z dnia 10 listopada 2005 r. w sprawie 55193/00 Schelling p. Austrii, LEX nr 165560; wyrok ETPCz z dnia 15 marca w sprawie 72701/01 Yakovlev p. Rosji, LEX nr 148937. 
nej może zostać także całkowicie unicestwiona $\mathrm{w}$ razie zobowiązania go do stawiennictwa na forum ponownego rozpoznania apelacji.

Ograniczenie udziału w rozprawie apelacyjnej oskarżonego chcącego aktywnie walczyć o uniewinnienie implikuje już formalizacja sygnalizacji chęci osobistego uczestnictwa w rozprawie przez rehabilitowanego objętego detencją - bez względu na powód i tryb umieszczenia przez legitymowany organ walczącego o pozbycie się statusu karanego w miejscu odosobnienia. Decyzję o sprowadzeniu oskarżonego pozbawionego wolności na rozprawę apelacyjną podejmuje bowiem sąd odwoławczy wyłącznie wówczas, gdy oskarżony w formie pisemnej złożył wniosek o doprowadzenie go na rozprawę, wbrew woli oskarżonego nie należy go zmuszać do osobistego uczestnictwa $\mathrm{w}$ procedurze rehabilitacyjnej. O prawie do złożenia wniosku należy pouczyć oskarżonego, niepouczenie lub mylne jego pouczenie może być kwalifikowane jako inne rażące naruszenie prawa procesowego, które in concreto może mieć istotny wpływ na treść wyroku sądu odwoławczego, a tym samym uzasadnić ponowne wniesienie kasacji (art. $523 \S 1$ k.p.k.). Celem przyspieszenia przebiegu postępowania złożenie wniosku o sprowadzenie na rozprawę odwoławczą ograniczono pod względem czasowym, oskarżony może bowiem wystąpić z odpowiednim żądaniem w terminie 7 dni od daty doręczenia mu zawiadomienia o przyjęciu apelacji. Brak wniosku pochodzącego od oskarżonego prawidłowo pouczonego jest tożsamy z jego świadomą rezygnacją z prawa do osobistego uczestnictwa $\mathrm{w}$ rozprawie apelacyjnej. Sprowadzenie oskarżonego znajdującego się w procedurze rehabilitacyjnej na odbywającą się ponownie rozprawę apelacyjną powinno stanowić regułę, osobiste uczestnictwo oskarżonego pozbawionego wolności umożliwia bowiem urzeczywistnienie zasady prawa do obrony oraz rzetelnego procesu, gwarantuje też kontradyktoryjność postępowania odwoławczego. Otwarcie rozprawy dla rehabilitowanego domagającego się osobistego udziału nie jest jednak automatyczne. Decydent może bowiem wykluczyć osobiste uczestnictwo pozbawionego wolności, uznając, że jego prawny interes przy rozpoznawaniu kwestii unicestwienia skutków skazania będzie wystarczająco reprezentowany przez obrońcę - już zajmującego się profesjonalną reprezentacją rehabilitowanego lub ustanawianego z urzędu przez sąd lub prezesa sądu dla samodzielnie walczącego o powrót do grona niekaranych, równocześnie z podjęciem decyzji o przeprowadzeniu postępowania uniewinniającego in absentia.

Kwestii obecności na rozprawie apelacyjnej nie pozostawiono w gestii rehabilitowanego objętego procedurą rehabilitacyjną wówczas, gdy prezes sądu lub sąd nałożą na niego obowiązek stawiennictwa. Zarówno sprowadzenie oskarżonego, z jakichkolwiek powodów znajdującego się $\mathrm{w}$ warunkach detencji, domagającego się uczestnictwa $\mathrm{w}$ rozprawie ape- 
lacyjnej, jak i zobligowanie rehabilitowanego do udziału w rozprawie powinno być regułą wówczas, gdy sąd planuje przeprowadzenie w instancji odwoławczej postępowania dowodowego ${ }^{54}$. Oskarżony znajdujący się $\mathrm{w}$ procedurze rehabilitacyjnej powinien być wówczas sprowadzony na rozprawę odwoławczą bez względu na stopień ewentualnych trudności natury organizacyjnej, jego żądanie powinno zostać uwzględnione nawet wtedy, gdy w ocenie sądu odwoławczego obecność oskarżonego na rozprawie apelacyjnej nie wpłynie na wynik kontroli odwoławczej ${ }^{55}$. De lege lata zamiast funkcjonującego do dnia 1 lipca 2015 r. modelu apelacji jako środka typu rewizyjnego obowiązuje bowiem model kontrolno-rozpoznawczy, przewidujący merytoryczne orzekanie w oparciu o materiał dowodowy skompletowany zarówno przez sąd I, jak i II instancji ${ }^{56}$ - gwarantowany zredukowaniem podstaw umożliwiających wydanie orzeczenia kasatoryjnego połączonego z następczym przekazaniem sprawy do ponownego rozpoznania i wymuszany możliwością złożenia nadzwyczajnego środka odwoławczego w postaci skargi na kasatoryjny wyrok sądu odwoławczego sprzężony z następczym przekazaniem sprawy do ponownego rozpoznania $\mathrm{w}$ razie bezzasadnego uchylenia wyro$\mathrm{ku}$ pierwszoinstancyjnego ${ }^{57}$. Tym samym nieobecność oskarżonego, lege

${ }^{54}$ D. ŚwIECKI: Rozprawa apelacyjna $w$ polskim procesie karnym. Kraków 2006, s. 57; IDEM: Obrona obligatoryjna na rozprawie apelacyjnej. W: Kodeks postępowania karnego. Komentarz do zmian 2016. Red. D. ŚwIECKI. Warszawa 2016, s. 529.

55 Wyrok Sądu Najwyższego z dnia 7 maja 2010 r., IV KK 369/09, KZS 2010, z. 11, poz. 27; wyrok Sądu Najwyższego z dnia 8 października 2009 r., IV KK 254/09, LEX nr 524060; wyrok Sądu Najwyższego z dnia 17 czerwca 2009 r., III KK 30/09, LEX nr 512125.

56 P. Hofmańsкi, S. Zaвєоскі: Sprawność postępowania odwoławczego $w$ świetle noweli do Kodeksu postępowania karnego z 27.9.2013 r. W: Między naukq a praktyka prawa karnego. Księga Jubileuszowa Profesora Lecha Gardockiego. Red. Z. JęDrzejEwski, M. KróLiKowsKi, Z. WiERNIKowsKi, S. ŻóŁTEK. Warszawa 2014, s. 107; M. FInGAS, S. STEINBorn: Granice rozpoznania sprawy $w$ instancji odwoławczej $w$ świetle nowelizacji Kodeksu postępowania karnego $z$ dnia 27 września 2013 r. i 20 lutego 2015 r. W: Obrońca i petnomocnik w procesie karnym po 1 lipca 2015 r. Przewodnik po zmianach. Red. P. WiLIŃski. Warszawa 2015, s. 488; M. KlejnowsKa: Dowodzenie co do meritum $w$ sprawie karnej $w$ postępowaniu apelacyjnym. RPEiS 2007, z. 1, s. 104; P. Rogoziński: Postępowanie dowodowe na rozprawie apelacyjnej $w$ sprawach karnych. SP 2010, z. 1, s. 151; A. SAKowICZ: Postępowanie dowodowe $w$ postępowaniu apelacyjnym. Zarys problematyki. W: Obrońca i petnomocnik $w$ procesie karnym po 1 lipca 2015 r. Przewodnik po zmianach..., s. 484; S. STEINBorn: Postępowanie dowodowe $w$ instancji apelacyjnej $w$ świetle nowelizacji Kodeksu postępowania karnego. Prok. i Pr. 2015, z. 1-2, s. 154; IDEM: Kształtowanie granic rozpoznania sprawy $w$ instancji odwoławczej $w$ procesie karnym $w$ świetle nowelizacji kodeksu postępowania karnego z 27 września 2013 r. i 20 lutego 2015 r. W: Reforma prawa karnego materialnego i procesowego z 2015 r. Red. D. Kala, I. ZgolińsKI. Warszawa 2015, s. 231.

${ }^{57} \mathrm{O}$ skardze na kasatoryjny wyrok sądu odwoławczego sprzężony z następczym przekazaniem sprawy do ponownego rozpoznania zob. P. CZARnecki: Skarga na wyrok 
non distinguente pozbawionego wolności i odpowiadającego z wolnej stopy, może go pozbawić udziału w przeprowadzaniu dowodów ścisłych dotyczących kwestii odpowiedzialności karnej, nie zaś - jak do 1 lipca 2015 r. - udziału w postępowaniu dowodowym co do istoty sprawy ściśle reglamentowanym, tzn. ograniczonym do przyspieszającego postępowanie uzupełnienia pierwszoinstancyjnego przewodu sądowego, niewymagającego przeprowadzenia na nowo w całości lub w znacznej części.

Kwestię obecności na rozprawie w przedmiocie ostatecznego uwolnienia od odpowiedzialności pozostawiono wyborowi rehabilitowanego także wówczas, gdy przywrócenie statusu osoby niewinnej wymaga powtórnego przeprowadzenia postępowania przed sądem in meriti. Udział rehabilitowanego $\mathrm{w}$ następczo toczącym się postępowaniu zwyczajnym $\mathrm{w}$ przedmiocie ostatecznego uwolnienia od odpowiedzialności za zarzucone przestępstwo ex lege jest fakultatywny (art. 374 § 1 k.p.k). Pewne utrudnienia $\mathrm{w}$ dostępie do rozprawy głównej, niezamykające jednak możliwości fakultatywnego uczestnictwa rehabilitowanego w ponownej rozprawie pierwszoinstancyjnej, obowiązują w razie, gdy rehabilitowany w jej trakcie znajduje się w warunkach detencji - bez względu na powód i tryb umieszczenia w miejscu odosobnienia.

Przeszkodę komplikującą dostęp do rozprawy głównej rehabilitowanego pozbawionego wolności implikuje obowiązek sformalizowanej sygnalizacji chęci uczestnictwa w rozprawie - warunkiem sprowadzenia oskarżonego objętego detencją na rozprawę główną jest bowiem złożenie przez niego pisemnego wniosku o doprowadzenie. Formalizacja dostępu do rozprawy głównej, z oczywistych względów, nie dotyczy takiego rehabilitowanego, który znajduje się w warunkach detencji, jednocześnie zaś został zobowiązany do udziału w rozprawie głównej ex lege lub ex institutio, tj. na podstawie decyzji uprawnionego czynnika sądowego. Możliwość złożenia wniosku podlega temporalnym ograniczeniom, tak by zarządzenie o doprowadzeniu na rozprawę główną zostało wydane w terminie zabezpieczającym logistykę skutecznego sprowadzenia oskarżonego z miejsca odosobnienia. Oskarżony może wystąpić z odpowiednim żądaniem w terminie 7 dni od daty doręczenia mu zawiadomienia o terminie rozprawy, wniosek złożony z przekroczeniem terminu zostanie rozpoznany wyłącznie wówczas, gdy nie spowoduje to konieczności zmiany terminu rozpra-

sqdu odwoławczego. (Non)sens nowego rozdziatu 55a k.p.k. CPKNP 2016, z. 2, s. 77-105; S. STEInBorn: Skarga na wyrok kasatoryjny sadu odwoławczego na tle systemu środków zaskarżenia $w$ polskim procesie karnym. W: Verba volant, scripta manent. Proces karny..., s. 415-428; D. Świecki: Skarga na wyrok sqdu odwoławczego. W: Kodeks postępowania karnego. Komentarz do zmian 2016..., s. 566; J. ZAGRODNIK: Instytucja skargi na wyrok sqdu odwoławczego (rozdziat 55 a k.p.k.) - zarys problematyki. W: Verba volant, scripta manent. Proces karny..., s. 519-535. 
wy - co oznacza, że spóźniony wniosek musi być złożony na tyle wcześnie przed rozpoczęciem rozprawy w pierwotnie wyznaczonym terminie, by sprowadzenie oskarżonego przebywającego $\mathrm{w}$ warunkach detencji, na miejsce i w czasie określone w zarządzeniu prezesa sądu o wyznaczeniu rozprawy lub w zarządzeniu przewodniczącego składu orzekającego wydanym na posiedzeniu organizacyjnym, w ogóle było możliwe.

Swobodę objętego procedurą rehabilitacyjną w zakresie decydowania o udziale w rozprawie zredukowano, statuując wyjątki na rzecz obowiązkowej obecności oskarżonego. Pierwszoinstancyjne procedowanie w przedmiocie odpowiedzialności karnej oskarżonego dążącego do sądowej rehabilitacji musi odbyć się w jego obecności w przypadku, gdy przewodniczący lub sąd zobowiążą oskarżonego do stawiennictwa na całej rozprawie lub w określonym fragmencie jej przebiegu. Decyzję obligującą do stawiennictwa najczęściej będzie dyktować konieczność wysłuchania wyjaśnień oskarżonego objętego procedurą rehabilitacyjną. De lege lata obecność starającego się o odzyskanie statusu osoby niekaranej jest obowiązkowa w części rozprawy toczącej się ponownie przed sądem in meriti w sprawach o zbrodnię - wyjątki na rzecz ustawowego obowiązku stawiennictwa obejmują okres, w którym dokonuje się otwarcia przewodu sądowego w ponownym pierwszoinstancyjnym postępowaniu oraz następuje pouczenie oskarżonego o przysługującym mu prawie do składania wyjaśnień, prawie do milczenia, prawie do składania wniosków dowodowych i konsekwencjach rezygnacji z tego prawa, o treści przepisów regulujących doręczenie wyroków zapadających na posiedzeniu, postanowień $\mathrm{z}$ odroczonym terminem sporządzenia uzasadnienia oraz doręczenie orzeczenia wraz z uzasadnieniem oraz o treści przepisów antyobstrukcyjnych i zasadach dotyczących pisemnego uzasadnienia wyroku.

\section{Prowadzenie rozprawy in absentia mimo obowiązku stawiennictwa rehabilitowanego na rozprawie}

Nie istnieją żadne prawne okoliczności typu argumentum ad impossibile, które z jednej strony wykluczałyby możliwość rezygnacji z obowiązkowej obecności niestającego oskarżonego albo obligatoryjnej lub fakultatywnej obecności stającego oskarżonego objętego procedurą rehabilitacyjną i odbycie rozprawy w całości lub w części in absentia, z drugiej zaś - uniemożliwiałyby zastosowanie środków przymusu procesowego celem uskutecznienia obowiązkowej obecności rehabilitowanego. Potrzeba uniknięcia bezradności sądu wobec obstrukcji procedury rehabilitacyjnej przez objętą nią osobę stanowi wystarczające ratio dla zastosowania przepisów antyobstrukcyjnych, umożliwiających rezygnację z obowiązkowej obec- 
ności oskarżonego znajdującego się w procedurze rehabilitacyjnej. Ogół rozpraw w procedurze rehabilitacyjnej, odbywających się z obowiązkowym udziałem oskarżonego rehabilitowanego, tj. rozprawy przed Sądem Najwyższym połączone z uniewinnieniem lub obejmujące wyłącznie rozpoznanie zasadności nadzwyczajnego środka odwoławczego, rozprawy przed sądem odwoławczym lub ponownie rozpoznającym sprawę sądem in meriti, może odbywać się w całości lub w części pod nieobecność rehabilitowanego zachowującego się obstrukcyjnie.

Sprawność i bezkolizyjność procedury rehabilitacyjnej wymaga bowiem skutecznej reakcji na obstrukcję rehabilitowanego, tj. na zachowania polegające na: 1) działaniu podjętym z własnej winy, celowo i świadomie wpływającym na stan zdrowia na tyle negatywnie, że stan ten, potwierdzony świadectwem lekarskim lub badaniami przeprowadzonymi za pomocą stosownego urządzenia pomiarowego, wyklucza udział w rozprawie ${ }^{58}$; 2) wyraźnym i niebudzącym wątpliwości oświadczeniu demonstrującym brak woli uczestnictwa w rozprawie ${ }^{59}$; 3) osobistym lub podjętym we współdziałaniu z innymi osobami uniemożliwianiem doprowadzenia na rozprawę, zdecydowanie (nierzadko z fizycznym zaangażowaniem oskarżonego) wyrażającym wolę nieuczestniczenia w rozprawie ${ }^{60}$; 4) nieusprawiedliwionym niestawiennictwie oskarżonego odpowiadającego z wolnej

58 Postanowienie SN z dnia 16 kwietnia 2008 r., IV KK 11/08, OSNSK 2008, z. 1, poz. 894; postanowienie SN z dnia 3 marca 2009 r., III KK 330/08, LEX nr 491166. Zob. też D. DrajEwicz: Nieobecność oskarżonego na rozprawie głównej (art. 377 k.p.k.). Prok. i Pr. 2014, z. 7-8, s. 40; T. GRZEGorczYK: Orzekanie pod nieobecność oskarżonego w postępowaniu karnym zwyczajnym $w$ świetle nowego kodeksu postępowania karnego. W: Nowe prawo karne procesowe. Poznań 1999, s. 270; R.A. STEFAńsKi: Postępowanie przed squdem I instancji. W: Kodeks postępowania karnego. Komentarz. T. 2. Red. Z. GostYŃsKI. Warszawa 2004, s. 664; M. URBANIAK: Rozpoznawanie spraw pod nieobecność oskarżonego $w$ polskim procesie karnym..., s. 81; IDEM: Prowadzenie rozprawy pod nieobecność oskarżonego - art. 377 k.p.k. Prok. i Pr. 2002, z. 3, s. 51.

59 Wyrok SN z dnia 17 września 2002 r., II KK 217/02, LEX nr 55536; postanowienie SN z dnia 8 listopada 2006 r., III KK 83/06, OSNKW 2007, z. 1, poz. 5; wyrok SN z dnia 3 listopada 2010 r., II KK 119/10, LEX nr 638477. Zob. też D. Drajewicz: Nieobecność oskarżonego na rozprawie głównej..., s. 45; T. GRzEGorczYK: Orzekanie pod nieobecność oskarżonego $w$ postępowaniu karnym zwyczajnym $w$ świetle nowego kodeksu postępowania karnego. W: Nowe prawo karne procesowe..., s. 270; R.A. STEFAŃsкi: Postępowanie przed sadem I instancji. W: Nowe prawo karne procesowe..., s. 664; M. UrbaniaK: Rozpoznawanie spraw pod nieobecność oskarżonego $w$ polskim procesie karnym..., s. 81; IDEM: Prowadzenie rozprawy pod nieobecność oskarżonego - art. 377 k.p.k..., s. 50.

${ }^{60}$ D. Drajewicz: Nieobecność oskarżonego na rozprawie głównej..., s. 46; T. GRzEGorCZYK: Orzekanie pod nieobecność oskarżonego $w$ postępowaniu karnym zwyczajnym $w$ świetle nowego kodeksu postępowania karnego. W: Nowe prawo karne procesowe..., s. 271; IDEM: O niektórych uproszczeniach procedury karnej $w$ nowym Kodeksie postępowania karnego. PS 1997, z. 9, s. 3; R.A. STEFAŃsKi: Postępowanie przed sądem I instancji. W: Kodeks postępowania karnego. Komentarz. T. 2..., s. 66; M. URBANIAK: Rozpoznawanie spraw pod nie- 
stopy, którego osobiście (na rozprawie odraczanej lub przerywanej albo wezwaniem, którego odbiór rehabilitowany własnoręcznie potwierdził) powiadomiono o terminie rozprawy $\left.{ }^{61} ; 5\right)$ opuszczeniu sali rozpraw przez rehabilitowanego bez zezwolenia przewodniczącego składu orzekającego $\mathrm{w}$ warunkach uzasadniających wiarygodne przypuszczenie, że niepozostanie do dyspozycji sądu nie zostało spowodowane przyczynami od oskarżonego niezależnymi ${ }^{62}$ oraz 6) nieusprawiedliwionym niestawiennictwie prawidłowo powiadomionego rehabilitowanego $\mathrm{w}$ terminie rozprawy przerwanej lub odroczonej.

Brak jest również przeciwwskazań do zastosowania w procedurze rehabilitacyjnej norm umożliwiających rezygnację z obecności oskarżonego w sprawach o konfiguracji wieloosobowej oraz statuujących podstawę do wykluczenia udziału oskarżonego obecnego na rozprawie. De lege lata takie zezwolenia dotyczą sytuacji, w których oskarżony przewleka i utrudnia bezproblemowy przebieg postępowania: 7) zachowaniami stanowiącymi obrazę sądu lub uporczywie naruszającymi porządek procedowania, kontynuowanymi pomimo upomnienia udzielonego rehabilitowanemu przez przewodniczącego składu orzekającego; 8) usprawiedliwionym niestawiennictwem niepozbawiającego się poprzez swoje niestawiennictwo możliwości realizacji obrony materialnej, niestającego po przerwaniu lub odroczeniu rozprawy w sprawach o konfiguracji wieloosobowej w części rozprawy przerwanej lub odroczonej niedotyczącej bezpośrednio nieobecnego oskarżonego z powodów usprawiedliwionych albo 9) krępującym oddziaływaniem na swobodę przesłuchiwanego współoskarżonego, świadka lub biegłego, grożącym odmową złożenia zeznań przez świadka, złożenia zeznań w całości lub choćby co do niektórych szczegółów niezgodnych z prawdą albo zatajeniem niektórych faktów o istotnym w sprawie znaczeniu ${ }^{63}$.

obecność oskarżonego $w$ polskim procesie karnym..., s. 81; IDEM: Prowadzenie rozprawy pod nieobecność oskarżonego - art. 377 k.p.k..., s. 56.

${ }^{61}$ Uchwała SN z dnia 28 marca 2002 r., I KZP 8/02, OSNKW 2002, z. 5-6; postanowienie SN z dnia 17 czerwca 2003 r., II KK 11/03, OSNSK 2003, z. 1, poz. 1304; postanowienie SN z dnia 25 maja 2010 r., I KZP 3/10, OSNKW 2010, z. 7, poz. 56; wyrok SN z dnia 5 listopada 2010 r., III KK 286/10, LEX nr 653513; wyrok SN z dnia 20 lipca 2011 r., V KK 218/11, LEX nr 897784; wyrok SN z dnia 3 lutego 2012 r., V KK 438/11, OSNKW 2012, z. 5, poz. 51; wyrok SN z dnia 2 kwietnia 2012 r., KK 442/11, LEX nr 1163988.

${ }^{62}$ W. JAsIŃsKI: Jawność wewnętrzna postępowania sądowego. W: Jawność procesu karnego..., s. 226; S. KALINOwsKI: Rozprawa główna $w$ polskim procesie karnym..., s. 194; J. ZduŃCZYK: Samowolne wydalenie się oskarżonego z rozprawy. „Gazeta Sądowa i Penitencjarna” 1968, z. 13.

${ }^{63}$ W. JAsIŃsKi: Jawność wewnętrzna postępowania sądowego. W: Jawność procesu karnego..., s. 226; S. KALINowsKi: Rozprawa główna w polskim procesie karnym..., s. 194; M. URbaniak: Rozpoznawanie spraw pod nieobecność oskarżonego w polskim procesie 
Gdyby zatem sam zainteresowany swoją obstrukcyjną postawą umyślnie zmierzał do opóźnienia lub utrudnienia rozstrzygnięcia, sąd uznający niekonieczność udziału oskarżonego - w trakcie całego przebiegu rozprawy (vide supra przypadki od pkt. 1 do 4) lub w tym jej fragmencie, który swoimi destrukcyjnymi zachowaniami oskarżony paraliżuje (vide supra przypadki od pkt. 5 do 9) - jest legitymowany do procedowania in absentia. Rezygnacja z obowiązkowej obecności oskarżonego objętego procedurą rehabilitacyjną i odbycie rozprawy w całości lub w części pod jego nieobecność dotyczy ogółu przypadków obowiązkowego stawiennictwa biernej strony procesu karnego. Konstruując przepisy statuujące okoliczności uzasadniajace procedowanie in absentia, zrezygnowano z jakiejkolwiek ich dyferencjacji według kryterium odwołującego się do źródła implikującego, wyjątkowy przecież, udział oskarżonego na forum rozstrzygającym kwestię jego odpowiedzialności karnej. Ustawodawca, konstytuując przesłanki uzasadniające zastosowanie przepisów antyobstrukcyjnych, posłużył się formułą ograniczającą ich zastosowalność do przypadków, w których udział oskarżonego w rozprawie lub posiedzeniu jest obowiązkowy. Ergo procedury rehabilitacyjne mogą toczyć się bez obecności rehabilitowanego zarówno wówczas, gdy obowiązek stawiennictwa ex lege statuują normy procedury karnej, jak i w przypadkach ustanowienia zobowiązania oskarżonego do stawiennictwa ex institutio decyzją Prezesa Sądu Najwyższego, Sądu Najwyższego, prezesa sądu lub sądu odwoławczego albo przewodniczącego składu lub sądu ponownie orzekającego w I instancji. Procedowanie absente reo nie może być jednak automatyczne, sąd może bowiem zrealizować prawo do procedowania pod nieobecność oskarżonego tylko po starannym rozważeniu tego, czy okoliczności sprawy uzasadniają skorzystanie z przepisów gwarantujących oskarżonemu prawo do osobistego działania w procesie ${ }^{64}$. Argumentum ad iudicium, tj. zasada zdrowego rozsądku, wskazuje jednak, że sąd nie powinien rezygnować z udziału oskarżonego zobligowanego do stawiennictwa decyzją czynnika sądowego. Trudno bowiem uznać za racjonalne działania organów wymiaru sprawiedliwości, najpierw arbitralnie ustanawiających obowiązek stawiennictwa oskarżonego objętego procedurą rehabilitacji, chwilę później zaś - w swoistym zabiegu tu quoque - negującego

karnym..., s. 73; B. WóJCicka: Jawność postępowania sq̨dowego $w$ polskim procesie karnym..., s. 27.

${ }^{64}$ Wyrok SN z dnia 5 lutego 2003 r., IV KKN 355/99, LEX nr 77433; postanowienie SN z dnia 12 listopada 2007 r., III KK 402/06, LEX nr 351209; wyrok SN z dnia 2 kwietnia 2012 r., V KK 442/11, LEX nr 1163988. Zob. też D. Drajewicz: Nieobecność oskarżonego na rozprawie głównej..., s. 39; R.A. STEFańsKi: Postępowanie przed sq̨dem I instancji. W: Kodeks postępowania karnego. Komentarz. T. 2..., s. 664; M. UrbaniaK: Prowadzenie rozprawy pod nieobecność oskarżonego - art. 377 k.p.k..., s. 58. 
poprzednią decyzję poprzez przyjęcie, że stawiennictwo rehabilitowanego zachowującego się destrukcyjnie jest niekonieczne. Zachowania naruszające sprawny i bezkolizyjny przebieg procedury rehabilitacyjnej nie unieważniają przecież przyczyn, dla których ex institutio nakazano stawiennictwo rehabilitowanego. Skoro bowiem najczęściej obligację stawiennictwa uzasadnia potrzeba zapewnienia osobistego udziału w przeprowadzaniu dowodów ścisłych dotyczących kwestii odpowiedzialności karnej starającemu się o rehabilitację, obecność oskarżonego znajdującego się w procedurze rehabilitacji - mimo jego obstrukcji - wciąż będzie konieczna.

De praxis ferenda przypadki ograniczeń wewnętrznej jawności rozprawy względem oskarżonego objętego procedurą rehabilitacyjną i zobowiązanego do stawiennictwa ex lege lub ex institutio decyzją organów wymiaru sprawiedliwości, choć prawnie możliwe, będą rzadkie - zupełnie niezrozumiałe byłoby bowiem obstrukcyjne zachowanie rehabilitowanego w końcowym etapie procedury zmierzającej do unicestwienia statusu osoby karanej, w zdecydowanej większości inicjowanej przecież przez samego zainteresowanego.

Osobną kwestią pozostaje to, czy w przypadkach uznania za konieczne stawiennictwo rehabilitowanego zobowiązanego do udziału w rozprawie ex lege lub ex institutio, sąd lub przewodniczący powinni korzystać z legitymacji do zarządzenia zatrzymania i przymusowego doprowadzenia przyznanego im na podstawie art. 376 § 1 i $\$ 2$ k.p.k. w przypadku niepozostawania przez rehabilitowanego do dyspozycji sądu lub niestającego po czasowym wstrzymaniu biegu rozprawy (vide supra przypadki wymienione w pkt. 5 i 6), na podstawie art. 377 \$ 3 k.p.k. w razie sygnalizacji woli niestawiennictwa, uniemożliwiania doprowadzenia albo niestawiennictwa mimo osobistego powiadomienia o terminie (vide supra przypadki od pkt. 2-4), a także na podstawie art. 382 k.p.k., wówczas gdy z innych powodów obecność rehabilitowanego jest obowiązkowa, np. obowiązek udziału implikuje ustanowione decyzją czynnika sądowego zobowiązanie do stawiennictwa. To, że uprawniony czynnik sądowy takim uprawnieniem dysponuje, pozostaje poza dyskusją, przepisy dotyczące obstrukcyjnych zachowań oskarżonego mają zastosowanie także względem oskarżonego tylko znajdującego się $\mathrm{w}$ procedurze rehabilitacji in completo, tj. zarówno w częściach określających podstawy do rezygnacji z obowiązkowej obecności biernej strony procesu karnego, jak i w częściach statuujących uprawnienie do skutecznego wymuszenia koniecznej obecności oskarżonego poprzez zastosowanie zatrzymania i przymusowego sprowadzenia $^{65}$. Korzystanie z formalnie dopuszczalnego uprawnienia do zasto-

${ }^{65}$ W. JAsIŃsKI: Jawność wewnętrzna postępowania sq̨dowego. W: Jawność procesu karnego..., s. 226; T. GrzegorczyK: Orzekanie pod nieobecność oskarżonego w postępowaniu 
sowania środków przymusu procesowego w procedurze rehabilitacyjnej niewątpliwie powinno jednak następować in extremis, tj. w ostateczności. Korelować to będzie z ogólną regułą umiaru w zakresie stosowania środków przymusu, każdorazowo ingerujących $\mathrm{w}$ sferę praw obywatelskich, zaś jej poszanowanie w postępowaniu toczącym się na korzyść osoby, wobec której należałoby je zastosować, wydaje się ze wszech miar wskazane.

\section{Niejawność tzw. szybkiej ścieżki rehabilitacyjnej}

Zupełnie zamknięty dla rehabilitowanego pozostaje każdy etap tzw. szybkiej ścieżki rehabilitacyjnej, tj. procedury przywrócenia do kategorii osób niewinnych bezpośrednio przez Sąd Najwyższy, stwierdzający na posiedzeniu oczywistą zasadność korzystnej dla oskarżonego kasacji i następczo uniewinniający skazanego od odpowiedzialności za przestępstwo inkryminowane rehabilitowanemu w sposób oczywiście niesłuszny. Posiedzenie rehabilitacyjne odbywa się bowiem według autonomicznych przepisów regulujących zasady jawności wewnętrznej. Tym samym nie znajdują zastosowania przepisy art. $96 \S 1-2$ k.p.k. oraz art. $96 \S 1 \mathrm{w} \mathrm{zw}$. $\mathrm{z}$ art. 451 k.p.k., będące lex generalis $\mathrm{w}$ zakresie udziału na posiedzeniu stron, w tym także udziału oskarżonego z jakichkolwiek powodów przebywającego $\mathrm{w}$ warunkach detencji oraz osób niebędących stronami, jeżeli uczestnictwo w posiedzeniu ma znaczenie dla ochrony ich praw lub interesów w postępowaniu. Deroguje je bowiem lex specialis, tj. art. $535 \S 5$ k.p.k., zgodnie z którym, wówczas gdy oczywista jest zasadność rehabilitacji, procedowanie $\mathrm{w}$ przedmiocie przywrócenia do kategorii osób formalnie niewinnych odbywa się całkowicie niejawnie wewnętrznie, a więc i bez udziału rehabilitowanego ${ }^{66}$. Przyspieszoną procedurę rehabilitacyjną oparto na założeniu o dorozumianej rezygnacji oskarżonego starającego się o unicestwienie stygmatu osoby skazanej z prawa do jawnego rozpoznania sprawy ${ }^{67}$. Niejawność wewnętrzna szybkiej ścieżki rehabilitacyjnej

karnym zwyczajnym $w$ świetle nowego kodeksu postępowania karnego. W: Nowe prawo karne procesowe..., s. 270; M. URBAnIaK: Rozpoznanie sprawy pod nieobecność oskarżonego..., s. 78; IDEM: Prowadzenie rozprawy pod nieobecność oskarżonego - art. 377 k.p.k..., s. 49 i nast.

${ }^{66}$ W. JASIŃsKI: Jawność wewnętrzna postępowania sq̨owego. W: Jawność procesu karnego..., s. 244; T. GrzegorczYK: Orzekanie pod nieobecność oskarżonego w postępowaniu karnym zwyczajnym $w$ świetle nowego kodeksu postępowania karnego. W: Nowe prawo karne procesowe..., s. 270; M. URBANIAK: Rozpoznanie sprawy pod nieobecność oskarżonego..., s. 188.

${ }^{67}$ Tak w odniesieniu do niejawnego wewnętrznie posiedzenia nakazowego m.in.: K. Eichstaedt: Postępowania szczególne w polskim procesie karnym. Warszawa 2010, s. 189; T. GRZEGORCZYK: Udziat stron i innych uczestników procesu w posiedzeniach sqdu $w$ sprawach 
nie narusza jednak reguł uczciwej i rzetelnej procedury, forum niedostępne dla stron warunkuje bowiem przekonanie sądu o braku potrzeby prowadzenia na rozprawie dodatkowych ustaleń co do okoliczności sprawy i winy sprawcy ${ }^{68}$. Istotą posiedzenia odbywającego się w ramach szybkiej ścieżki rehabilitacyjnej jest non solum brak potrzeby dowodzenia, sed etiam niedokonywanie żadnych czynności związanych z rozpoznaniem sprawy ${ }^{69}$. Ergo, dostęp stron do forum rozpoznającego jednoznaczną i niebudzącą wątpliwości kwestię odpowiedzialności karnej jest zbędny, prowadzenie defensywno-ofensywnego sporu wymagającego ich udziału nie jest bowiem konieczne do prawidłowego rozstrzygnięcia o zasadniczym przedmiocie procesu.

Żadne szczególne względy, np. dobro wymiaru sprawiedliwości, interes społeczny, prawny interes oskarżonego znajdującego się w procedurze rehabilitacji itp., nie uzasadniają dopuszczenia jakiegokolwiek zainteresowanego do udziału w posiedzeniu niejawnym ex lege ${ }^{70}$. Szybka ścieżka rehabilitacyjna pozostaje zatem zamknięta zarówno dla oskarżonego objętego procedurą rehabilitacji, pokrzywdzonego mającego status oskarżyciela posiłkowego lub prywatnego, prokuratora, jak i osób niebędących stronami, choćby mogło to mieć znaczenie dla ochrony ich praw i interesów, np. ze względu na pokrzywdzenie osoby, która nie nabyła statusu strony. Zezwolenie na ich uczestnictwo w szybkiej ścieżce rehabilitacyjnej stanowiłoby bowiem nieznane procedurze karnej exceptio od czterech typów jawności wewnętrznej posiedzeń. Posługując się kryterium dostępu posiedzeń dla stron, można fora posiedzeniowe skategoryzować jako:

karnych. W: Nauki penalne wobec problemów wspótczesnej przestępczości. Księga jubileuszowa $z$ okazji 70. rocznicy urodzin profesora Andrzeja Gaberle. Red. K. KRAJEWSKI. Warszawa 2007, s. 182; Cz.P. KŁaK: Postępowanie nakazowe w polskim procesie karnym a ochrona praw człowieka. Warszawa 2008, s. 212; E. KruK: Postępowanie nakazowe. W: Tryby szczególne. System Prawa Karnego Procesowego. T. 14. Red. F. PrusaK. Warszawa 2015, s. 446; D. ŚwIEcKI: Bezpośredniość czy pośredniość w polskim procesie karnym. Warszawa 2012, s. 140.

${ }^{68}$ Identycznie w odniesieniu do braku potrzeby dokonywania ustaleń faktycznych na posiedzeniu nakazowym zob. wyrok SN z dnia 23 lutego 2012 r., III KK 480/11, KZS 2014, z. 1, poz. 30; wyrok SN z dnia 7 marca 2012 r., II KK 30/12. Wkł. w Prok. i Pr. 2012, z. 6, poz. 9; wyrok SN z dnia 17 kwietnia 2000 r., IV KKN 157/99. Wkł. w Prok. i Pr. 2000, z. 10, poz. 10; wyrok SN z dnia 6 lipca 1995 r., III KRN 56/97. Wkł. w Prok. i Pr. 1995, z. 11-12, poz. 13.

69 Takie założenie w odniesieniu do niejawnego wewnętrznie posiedzenia nakazowego przyjął D. Świecki. Zob. D. ŚwIEcki: Bezpośredniość czy pośredniość w polskim procesie karnym..., s. 139.

${ }^{70}$ Pogląd o możliwości dopuszczenia stron do udziału w posiedzeniu nakazowym odbywającym się bez udziału stron, w razie gdy przemawia za tym dobro wymiaru sprawiedliwości, wyraził R.A. StefańsKi. Zob. R.A. Stefański: Postępowanie nakazowe w znowelizowanym Kodeksie postępowania karnego. Prok. i Pr. 2003, z. 7-8, s. 17; IDEM: Postępowanie nakazowe. W: Kodeks postępowania karnego. Komentarz. T. 3. Red. Z. GostyŃski. Warszawa 2004, s. 425. 
1) posiedzenia odbywające się z obligatoryjnym udziałem stron lub także innych uczestników postępowania, zobowiązanych do stawiennictwa na podstawie ustawy lub w oparciu o treść postanowienia lub zarządzenia wydanego przez uprawniony organ wymiaru sprawiedliwości;

2) posiedzenia otwarte dla stron i innych uczestników w sposób bezwzględny, co oznacza, że zainteresowani mają bezwzględne uprawnienie do udziału implikowane przez przepis szczególny, zawierający legitymacje do udziału na forum posiedzeniowym i ewentualne wskazanie na konkretnych uczestników wyposażanych w bezwzględne prawo udziału;

3) posiedzenia dostępne dla stron i innych uczestników w sposób względny, tj. posiedzenia, co do których brak jest szczególnych regulacji dotyczących obowiązku, prawa lub zakazu uczestnictwa stron lub innych zainteresowanych podmiotów, zaś wewnętrzną jawność określa przepis ogólny zawarty w art. 96 \$ k.p.k., zezwalający stronom oraz osobom niebędącym stronami, jeżeli kwestie będące przedmiotem posiedzenia mają znaczenie dla ochrony ich praw i interesów, na udział w posiedzeniu pod warunkiem samodzielnego stawiennictwa zainteresowanych, tj. stawiennictwa mimo braku zawiadomienia o miejscu i czasie posiedzenia, co uzależnia ich udział w forum posiedzeniowym od tego, czy zainteresowanym we własnym zakresie uda się dowiedzieć o terminie i miejscu procedowania oraz

4) posiedzenia odbywające się bez udziału stron, dla których forum posiedzeniowe jest zamknięte na podstawie przepisu expressis verbis wykluczającego uczestnictwo stron i innych podmiotów ${ }^{71}$.

Wyraźna kategoryzacja typów jawności wewnętrznej posiedzeń i ustawowe skonfigurowanie posiedzenia odbywającego się w Sądzie Najwyższym w ramach szybkiej ścieżki rehabilitacyjnej według wzorca typizującego jeden z rodzajów jawności forum posiedzeniowego wyklucza jakiekolwiek modyfikacje wybranego rodzaju jawności decyzjami organów wymiaru sprawiedliwości. Transpozycja posiedzenia zupełnie zamkniętego w posiedzenie odbywające się z udziałem strony, czy też stron, jest tym bardziej nieakceptowalna, że en tout cas decyzja Prezesa Sądu Najwyższego lub Sądu Najwyższego kreowałaby zupełnie nowy typ jawności wewnętrznej. Żadna kodeksowa regulacja dostępu do posiedzenia stron, czy też innych zainteresowanych, nie przewiduje bowiem zmiany forum niejawnego w jawne, ogół przypadków, w których ustawa oddaje kwestię otwarcia posiedzenia dla stron lub innych podmiotów organom

${ }^{71}$ P. HofmańsKi, E. SADZIK, K. ZgryzeK: Kodeks postępowania karnego. T. 1: Komentarz do art. 1-296. Red. P. HofmańsKi. Warszawa 2004, s. 475. 
wymiaru sprawiedliwości, obejmuje poszerzanie jawności posiedzeń i tak już dostępnych dla uczestników postępowania. Jawność wewnętrzna posiedzenia ustanawiana ex institutio obejmuje wyłącznie przekwalifikowanie posiedzenia otwartego dla stron w sposób bezwzględny w posiedzenie toczące się z obligatoryjnym udziałem stron lub innych zainteresowanych. Typowa konstrukcja przepisu stanowiącego rozszerzające wyjątki od ustanowionego jako lex generali względnego uprawnienia stron lub innych podmiotów do udziału w posiedzeniu obejmuje wyraźnie statuowane uprawnienie zainteresowanych do udziału w posiedzeniu (np. prokurator, oskarżony i pokrzywdzony mogą wziąć udział w posiedzeniu ${ }^{72}$ ) oraz ewentualnie dookreślenie, że zarządzeniem lub postanowieniem możliwe jest nałożenie na określonych uczestników postępowania obowiązku stawiennictwa (np. ich udział jest obowiązkowy, jeżeli prezes sądu lub sąd tak zarządzi $\left.{ }^{73}\right)$. Lex specialis na rzecz otwarcia posiedzenia decyzją czynnika sądowego są więc konstruowane dwustopniowo - w pierwszej kolejności ustawodawca przekształca względne prawo udziału w prawo o charakterze bezwzględnym, następnie zaś ustanawia kompetencję prezesa sądu lub sądu do przekształcenia posiedzenia toczącego się z fakultatywnym udziałem stron $\mathrm{w}$ forum odbywające się $\mathrm{w}$ warunkach obowiązkowego stawiennictwa.

\subsection{Dostępność rozpraw rehabilitacyjnych dla obligatoryjnego obrońcy rehabilitowanego}

W staraniach o prawne unicestwienie skutków nieprawidłowego skazania rehabilitowanego może, a w niektórych przypadkach musi, uczestniczyć jego obrońca. Otwarcie poszczególnych forów poświęconych procedowaniu w przedmiocie formalnego przywrócenia do kategorii osób niekaranych dla profesjonalnego reprezentanta rehabilitowanego warunkuje charakter obrony, poziom sądu ostatecznie przywracającego do kategorii osób prawnie niewinnych oraz rzeczywiste uczestnictwo samego rehabilitowanego. Per se zrozumiałe jest, że ogół rozpraw odbywających się w procedurze rehabilitacyjnej dostępnych dla oskarżonego pozostaje

72 Egzemplifikacyjnie art. 341 § 1 zd. pierwsze k.p.k., kreujący jawność wewnętrzną względem prokuratora, oskarżonego i pokrzywdzonego posiedzenia w przedmiocie warunkowego umorzenia postępowania; art. $343 \S 5$ zd. pierwsze k.p.k. ustanawiający bezwzględne uprawnienie prokuratora, oskarżonego i pokrzywdzonego na posiedzeniu w przedmiocie wniosku o wydanie na posiedzeniu wyroku skazującego i orzeczenie uzgodnionych $\mathrm{z}$ oskarżonym kar lub innych środków przewidzianych za zarzucany mu występek.

${ }^{73}$ Zob. art. $341 \S 1$ zd. drugie k.p.k. albo art. $343 \S 5$ zd. trzecie k.p.k.. 
otwarty także dla jego obrońcy. Nadto uproszczona byłaby bowiem - nasuwająca się prima facie - teza, zgodnie z którą dostępność procedury rehabilitacyjnej dla obrońcy starającego się o unicestwienie prawnych skutków skazania kształtuje się identycznie jak jej otwarcie w stosunku do samego zainteresowanego. Dla skutecznej reprezentacji interesów przywracanego do grona osób prawnie niewinnych obrońca jest zobligowany do uczestnictwa w procedurze rehabilitacyjnej w zakresie szerszym niż sam zainteresowany.

$\mathrm{Na}$ profesjonalnego reprezentanta rehabilitowanego nałożono bowiem obowiązek uczestnictwa w rozprawach dotyczących kwestii unicestwienia wyroku, następnie zaś oficjalnego uwolnienia od odpowiedzialności za przestępstwo zarzucone rehabilitowanemu w każdym przypadku rzeczywistych lub przewidywanych utrudnień w samodzielnych staraniach o powrót do kategorii niekaranych.

Trudności w aktywnym i samodzielnym prezentowaniu argumentów na rzecz rehabilitacji - generujące obligatoryjną obronę formalną, ergo obligatoryjne uczestnictwo w rozprawach rehabilitacyjnych obrońcy interesów starającego się o unicestwienie skutków skazania - mogą przede wszystkim wynikać z przyczyn podmiotowych, tj. z fizycznego i psychicznego stanu zdrowia oskarżonego, jego wieku oraz innych powodów utrudniających obronę (art. 79 § 1 k.p.k. oraz art. 79 § k.p.k.). Jawność wewnętrzna rozpraw rehabilitacyjnych, obejmująca osobisty i rzeczywisty udział profesjonalnego przedstawiciela osoby przywracanej do grona osób niekaranych, jest bowiem najszersza właśnie wówczas, gdy obligatoryjny charakter obrony formalnej generuje: 1) małoletniość oskarżonego w czasie prowadzenia postępowania bez względu na stadium, w jakim toczy się proces; 2) całkowite zniesienie lub znaczne ograniczenie funkcjonowania zmysłu wzroku, słuchu i mowy; 3) istniejące hic et nunc wątpliwości co do tego, czy zdolność rozpoznania znaczenia czynu lub kierowania postępowaniem in tempore criminis nie była wyłączona lub w znacznym stopniu ograniczona; 4) aktualne, uzasadnione wątpliwości co do tego, czy stan zdrowia psychicznego oskarżonego starającego się o uniewinnienie in tempore procedendi pozwala mu - przy odwołaniu się do wzorca przeciętnego zachowania, obejmującego faktyczną możliwość oceny własnego zachowania i realizacji przysługujących uprawnień - na udział w postępowaniu lub umożliwia mu prowadzenie obrony w sposób samodzielny i rozsądny ${ }^{74}$; 5) uznanie przez sąd obrony za niezbędną ze

${ }^{74}$ M. KlejnowsKa: Prawo do samodzielnej i rozsadnej obrony $w$ świetle nowelizacji Kodeksu postępowania karnego z dnia 27 września 2013 r. W: Wokót gwarancji współczesnego procesu karnego. Księga jubileuszowa profesora Piotra Kruszyńskiego. Red. B.T. BIEŃKowsKA, H. Gajewska-Kraczkowska, M. Rogacka-Rzewnicka. Warszawa 2015, s. 222; S. Ładoś: Watpliwości co do stanu zdrowia psychicznego jako przesłanka obligatoryjnej obrony formal- 
względu na inne okoliczności utrudniające obronę, nie uniemożliwiające, ale $\mathrm{w}$ znaczny sposób utrudniające realizację prawa do obrony materialnej bezpośrednio przez oskarżonego, najczęściej sprzężone z właściwościami: fizycznymi (wiekiem, stanem zdrowia, sprawnością poszczególnych narządów zmysłu), psychicznymi (stopniem sprawności umysłowej, niezaradnością, nieporadnością) oraz intelektualnymi (stopniem inteligencji ogólnej, wiedzą w dziedzinie stanowiącej przedmiot przedstawionych zarzutów) konkretnego oskarżonego ${ }^{75}$. Prawną podstawę obowiązku profesjonalnej reprezentacji rehabilitowanego na rozprawie $\mathrm{w}$ przypadkach rzeczywistych lub potencjalnych problemów z samodzielnym prezentowaniem własnych interesów stanowią istniejące verba legis zapisy (art. 79 § 3 k.p.k. oraz art. 450 § 1 k.p.k.), statuujące obowiązek uczestnictwa obrońcy oskarżonego odpowiednio w rozprawach odbywających się przed sądem in meriti oraz rozprawach apelacyjnych w postępowaniu odwoławczym, albo przepisy przetransponowane na grunt określonych procedur w oparciu o normy odsyłające - tak obowiązek profesjonalnej reprezentacji oskarżonego istniejący ze względów podmiotowych ukonstytuowano na poziomie Sądu Najwyższego procedującego w ramach rozpoznania kasacji (art. 518 k.p.k. w zw. z art. 450 § 1 k.p.k.).

Nota bene, przepisy osobno regulujące obowiązek stawiennictwa obrońcy oskarżonego reprezentowanego obligatoryjnie ze względów podmiotowych w rozprawie apelacyjnej i kasacyjnej (art. 450 § 1 k.p.k. oraz art. 518 k.p.k. w zw. z art. $450 \S 1$ k.p.k.) stanowią klasyczne superfluum. Art. $79 \S 3$ k.p.k. ulokowano w rozdziale dotyczącym oskarżonego, umieszczając w nim komplet informacji dotyczących obligatoryjnej obrony formalnej legitymowanej małoletnością lub stanem zdrowia, tj. jej przesłanki, obowiązek ustanowienia, okoliczności uzasadniające cofnięcie obrony oraz zasadę obligatoryjnego udziału profesjonalnego reprezen-

nej. W: T. Gardocka, et al: Prawo do obrony w postępowaniu penalnym. Wybrane aspekty. Warszawa 2014, s. 88.

75 R. RYNKUn-Werner: Adwokat z urzędu. Podstawowe zagadnienia prawne. Warszawa 2011, s. 116; R.A. STEFAŃSKI: Obrona obligatoryjna $w$ polskim procesie karnym. Warszawa 2012; s. 264; IDEM: Obrona obowiązkowa - prawo czy konieczność?. W: Wspótczesne tendencje $w$ rozwoju procesu karnego z perspektywy dogmatyki oraz teorii i filozofii prawa. Red. J. SKorupKa, I. Hä̈DuK-HawrylaK. Warszawa 2011, s. 98; IDEM: Konstytucyjne prawo do obrony a obrona obligatoryjna $w$ świetle noweli z dnia 27 września 2013 r. W: T. GARDOCKA et al.: Prawo do obrony $w$ postępowaniu penalnym. Wybrane aspekty..., s. 17; P. WiLIŃsKI: Zasada prawa do obrony $w$ polskim procesie karnym. Warszawa 2006; IDEM: Zasada prawa do obrony. W: System Prawa Karnego Procesowego. Zasady procesu karnego. T. 3. Cz. 2..., s. 1479; K. ZGRYZEK: Obrona obligatoryjna - czy rzeczywiście konieczna? Uwagi na marginesie art. 79 k.p.k. W: Węzłowe problemy procesu karnego..., s. 633-644; IDEM: Prawo do obrony po nowelizacji wrześniowej: kilka uwag. W: Wokót gwarancji wspótczesnego procesu karnego..., s. 551. 
tanta oskarżonego na rozprawie oraz w tych posiedzeniach, w których obowiązkowy jest udział oskarżonego. Ulokowanie ogółu przepisów dotyczących formalnej obrony obligatoryjnej przysługującej ze względów podmiotowych w części Kodeksu postępowania karnego normującej statykę procesu, sprzężone z użyciem nazwy „rozprawa”, bez dookreślania jej rodzaju, uprawnia do afirmacji tezy o zastosowalności art. 79 \$ 3 k.p.k. do ogółu rozpraw odbywających się in casu, pod warunkiem zachodzenia w ich trakcie przesłanek uzasadniających obligatoryjną obronę ustanawianą dla oskarżonego ze względów podmiotowych. Ergo zakresem zastosowalności ogólnego przepisu statuującego obowiązek udziału obrońcy reprezentującego oskarżonego ze względu na wiek lub trudności z obroną materialną generowane stanem zdrowia psychicznego i fizycznego obejmuje rozprawy toczące się w typowym (rozprawa główna) i wzbogaconym (rozprawa apelacyjna i kasacyjna) toku procesu oraz rozprawy odbywające się w postępowaniach toczących się po uprawomocnieniu się orzeczenia, tj. rozprawę toczącą się w przedmiocie odszkodowania za niesłuszne skazanie oraz niewątpliwie niesłuszne tymczasowe aresztowanie lub zatrzymanie, a także rozprawę odbywającą się w przedmiocie wydania wyroku łącznego. Tym samym zbędny jest art. 450 § 1 k.p.k., stanowiący umieszczoną w rozdziale o apelacji jednostkę redakcyjną zawierająca zobowiązanie do stawiennictwa na rozprawie apelacyjnej, w postępowaniu kasacyjnym niepotrzebne jest również odpowiednie stosowanie przepisu o obowiązkowym udziale obligatoryjnego obrońcy oskarżonego w rozprawie apelacyjnej (art. 518 k.p.k. w zw. z art. 450 \$ 1 k.p.k.). Samo powtórzenie w całości zapisu jednego przepisu w drugim wystarcza bowiem do uznania jednego z nich za nadmiarowy, niezależnie od tego, czy zdublowanie nastąpiło w sposób świadomy, jaką treść powtórzono oraz czy przyczyniło się to do usprawnienia potencjalnej wykład$n i^{76}$. I choć przepisów prawnych nie należy interpretować zakładając, iż niektóre ich fragmenty są zbędne, tezę o jedynie deklaratywnym znaczeniu formuł nakazujących stawiennictwo obligatoryjnego obrońcy ustanowionego z przyczyn podmiotowych na rozprawach dotyczących odzyskania statusu osoby niekaranej tym łatwiej afirmować, że w Kodeksie postępowania karnego nie brak norm stanowiących jedynie powtórzenie uprzednio sformułowanych reguł ogólnych. Tytułem przykładu - w art. 506 \$ 1 k.p.k., określając długość terminu do wniesienia sprzeciwu od wyroku nakazowego, sklasyfikowano go jako termin zawity. Zgodnie zaś $\mathrm{z}$ definicją sformułowaną w art. 122 \$ 2 k.p.k. zawitymi są terminy do

${ }^{76}$ M. KŁodAwski: Superfluum i nadwyżki znaczeniowe jako przykłady redundancji tekstu prawnego. „Archiwum Filozofii Prawa i Filozofii Społecznej” 2013, z. 2, s. 39; A. MaŁochAKrupa: Stowa w lustrze. Pleonazm - semantyka - pragmatyka. Wrocław 2003, s. 19. 
wnoszenia środków zaskarżenia - lege non distinguente status zawitego ma także termin do zakwestionowania wyroku wydanego w trybie nakazowym. Tym samym charakterystyka zawarta w art. $506 \S 1$ k.p.k., będąc jedynie powtórzeniem normy definiującej, nie może być potraktowana inaczej niż jako nadregulacja. Regulując zasady obowiązkowej obecności obligatoryjnego obrońcy ustanawianego ze względów podmiotowych na rozprawach odbywających się $\mathrm{w}$ sprawie oskarżonego małoletniego lub mającego trudności z obroną materialną generowane stanem zdrowia psychicznego i fizycznego, ustawodawca, niejedyny więc raz na gruncie ogółu norm procesowych, hołdując zasadzie Superflua admittere securius est, quam necessaria omittere (tj. bezpiecznej jest dopuścić rzeczy zbyteczne aniżeli opuścić rzeczy konieczne), dopuścił się nieszkodliwego nadmiaru legislacyjnego. Nadmiar regulacji dotyczących tych samych stosunków społecznych nie jest wadliwy, stanowi bowiem przykład redundancji tekstu prawnego, rozumianej jako intencjonalne duplikowanie dokonywanej w celu zabezpieczenia skutecznej komunikacji na linii ustawodawca odbiorca tekstu prawnego ${ }^{77}$.

Na podstawie normy ogólnej, odnoszącej się do wszystkich rozpraw odbywających się in casu oraz będącej nieszkodliwym nadmiarem legislacyjnym normy odnoszącej się bezpośrednio i pośrednio do rozpraw apelacyjnych i kasacyjnych, profesjonalny reprezentant osoby rehabilitowanej jest obligowany do osobistej obecności i rzeczywistej aktywności, $\mathrm{w}$ toku wszystkich rozpraw odbywających się $\mathrm{w}$ procedurze zmierzającej do odzyskania statusu osoby niewinnej. In effectu obrońca interesów przywracanego do grona osób niekaranych jest zobowiązany do uczestnictwa w rozprawach przed Sądem Najwyższym procedującym wyłącznie $\mathrm{w}$ przedmiocie zasadności kasacji lub badającym następczo również kwestię uniewinnienia rehabilitowanego skazanego w oczywiście nieprawidłowy sposób; profesjonalny przedstawiciel rehabilitowanego jest zobowiązany osobiście stawić się również na rozprawę odbywającą się przed sądem odwoławczym lub pierwszoinstancyjnym, badającą kwestię odpowiedzialności karnej rehabilitowanego po uchyleniu wyroku i następczym jej przekazaniu do powtórnego rozpoznania.

Równie szeroki zakres ma zobowiązanie do udziału w rozprawach obligatoryjnego obrońcy oskarżonego znajdującego się w procedurze rehabilitacji, ustanawianego dla niego ze względów przedmiotowych, tj. z uwagi na pierwszoinstancyjną właściwość sądu okręgowego skumulowaną $\mathrm{z}$ zastosowaną $\mathrm{w}$ akcie oskarżenia kwalifikacją czynu inkryminowanego oskarżonemu jako zbrodni (art. 80 k.p.k.). Identyczny zakres obowiąz$\mathrm{ku}$ udziału $\mathrm{w}$ rozprawach odbywających się $\mathrm{w}$ procedurze rehabilitacyj-

77 M. KŁodawsKi: Superfluum i nadwyżki znaczeniowe..., s. 39. 
nej obrońcy obligatoryjnego ustanawianego ze względów podmiotowych i przedmiotowych jest implikowany generalną zasadą analogicznego traktowania ogółu przypadków obrony obligatoryjnej, ustanawianej w toku postępowania odbywającego się $\mathrm{w}$ przedmiocie odpowiedzialności karnej oskarżonego. Lege non distinguente zasada równego ukształtowania praw i obowiązków obrońców obligatoryjnych reprezentujących oskarżonego $\mathrm{w}$ toku postępowania $\mathrm{w}$ przedmiocie odpowiedzialności karnej funkcjonuje zarówno wówczas, gdy niezawodowa obrona karna byłaby niesprawna ze względu na fizyczny i psychiczny stan zdrowia oskarżonego oraz jego wiek (art. 79 § 1 i 2 k.p.k.), jak i w sytuacji utrudnień w osobistym zwalczaniu tez oskarżenia powodowanych wagą stawianych zarzutów (art. 80 k.p.k.).

\section{Zasada analogicznych uprawnień i obowiązków obligatoryjnej obrony ustanawianej ze względów przedmiotowych i podmiotowych}

Na ogół normy prawne wyposażają w jednakowy wachlarz uprawnień obrońców przysługujących tak ze względu na stan zdrowia, wiek oskarżonego, jak i na wagę stawianych zarzutów; tak samo opisują też rodzaj zachowań im nakazanych oraz ujednolicają prawne konsekwencje ewentualnych uchybień w zakresie obrony formalnej, obligatoryjnej w razie potencjalnych utrudnień w samodzielnej prezentacji swoich interesów procesowych przez oskarżonego. Egzemplifikacyjnie - otóż nie ma żadnych różnic $\mathrm{w}$ określeniu następstw przeprowadzenia postępowania sądowego bez ustanowienia i udziału w obowiązkowych czynnościach procesowych obrońcy przysługującego ze względu na stan zdrowia oskarżonego, jego wiek, wagę zarzuconych czynów oraz trwające pozbawienie wolności. Bez względu więc na to, jaka jest przyczyna utrudnień w wyłącznie osobistej realizacji funkcji obrony przez samego oskarżonego, nieposiadanie profesjonalnego przedstawiciela lub przeprowadzenie czynności in absentia obowiązkowego stawiennictwa profesjonalnego reprezentanta oskarżonego stanowi uchybienie kwalifikowane jako bezwzględna przyczyna uchylenia orzeczenia (art. $439 \S 1$ pkt 10 k.p.k.). Niezależnie od przyczyny potencjalnych problemów w niezawodowej reprezentacji interesów procesowych oskarżonego błędy w zakresie obligatoryjnej obrony formalnej stanowią podstawę apelacji (art. $439 \S 1$ pkt 10 k.p.k.), kasacji (art. $523 \S 1$ k.p.k.), skargi na kasatoryjny wyrok sądu odwoławczego sprzężony z następczym przekazaniem sprawy do ponownego rozpoznania (art. 539a § 1 k.p.k.) oraz następującego ex officio wznowienia postępowania (art. 542 $\S 3$ k.p.k.); ich ujawnienie w toku postępowania odwoławczego i nadzwyczajno-odwoławczego, uruchomionych z innych powodów, umożliwia 
orzekanie poza zakresem zaskarżenia i podniesionych zarzutów (art. 439 § 1 in principio k.p.k., art. 536 k.p.k. oraz art. 539f k.p.k. w zw. z art. 536 k.p.k.), zaś eliminacja orzeczeń wydanych mimo braku lub niestawiennictwa obrońcy jest możliwa tylko celem poprawienia procesowego położenia oskarżonego pozbawionego profesjonalnej reprezentacji w ogóle lub w toku konkretnej czynności (art. 439 § 2 k.p.k. oraz art. $542 \S 3$ k.p.k.).

Jedyne ustawowe zróżnicowanie zasad wykonywania obrony niezbędnej ze względu na stan zdrowia fizycznego lub psychicznego albo wiek oskarżonego (art. 79 k.p.k.) oraz obrony obligatoryjnej przysługującej oskarżonemu ze względu na wagę zarzucanego mu czynu (art. 80 k.p.k.), funkcjonujące $\mathrm{w}$ toku procedowania $\mathrm{w}$ przedmiocie odpowiedzialności karnej, dotyczy dopuszczalności samodzielnego cofnięcia przez oskarżonego środka odwoławczego wniesionego przez obligatoryjnego obrońcę z uruchomienia zwyczajnego lub nadzwyczajnego postępowania odwoławczego bez żadnych ograniczeń może zrezygnować oskarżony o zbrodnię, z kolei oskarżonemu bronionemu przez fachowego przedstawiciela ze względu na właściwości psychiczne, stan zdrowia lub wiek zablokowano możliwość dysponowania środkiem odwoławczym obrońcy (art. 431 § 2 k.p.k.). Zasady profesjonalnego wykonywania funkcji obrony zróżnicowano w odniesieniu do czynności wymagającej działania z absolutną świadomością i pełnym rozeznaniem, tak aby nie było żadnych wątpliwości, że wolą oskarżonego jest rezygnacja z kontroli orzeczenia uznanego za wadliwe przez podmiot profesjonalnie przygotowany do występowania przed sądem. Ex thesi jest to bowiem podmiot wyposażony w wiedzę specjalistyczną, jakiej całkowicie pozbawiona jest bierna strona procesu, mający też daleko większe niż oskarżony doświadczenie w argumentowaniu przeciwko tezom oskarżenia - z dużym więc prawdopodobieństwem dostrzegający nieuchwytne dla oskarżonego uchybienia będące udziałem sądu I lub II instancji, rokujące szanse na zmianę lub uchylenie niekorzystnego dla klienta orzeczenia. Dostateczną sprawnością psychiczną, warunkującą brak przeszkód w podjęciu i wyrażeniu woli dysponowania skargą, z pewnością dysponuje natomiast oskarżony o zbrodnię. Objęcie tej grupy oskarżonych obligatoryjną obroną formalną następuje przecież nie ze względu na stan psychiczny, utrudniający samodzielną obronę, generują ją bowiem potencjalne problemy, jakie w prezentowaniu własnych racji przez osobę całkowicie zdolną do dokonywania prawidłowych czynności procesowych może wywołać stopień skomplikowania sprawy. $\mathrm{Z}$ kolei w przypadku osób obligatoryjnie reprezentowanych przez profesjonalnego przedstawiciela ze względu na zniesienie zmysłów, zaburzenia psychiczne lub wiek można mieć niemal pewność braku wystarczającej orientacji warunkującej prawidłowość powzięcia i wyrażenia woli rezygnacji z kontroli orzeczenia. Tym samym całkowicie zrozumiała staje się 
możliwość samodzielnej realizacji pojedynczej czynności, opozycyjnej w stosunku do stanowiska zawodowego reprezentanta, przez oskarżonych mających dostateczną świadomość jej znaczenia oraz niedopuszczalność wykonania tej samej czynności przez osoby z różnych powodów niezdolne do prawidłowego powzięcia i wyrażenia swojej woli. Całkowicie uzasadnione jest więc zróżnicowanie zasad wykonywania obrony obligatoryjnej przysługującej ze względu na zaburzenia psychologiczne, psychiatryczne, powodowanej wiekiem lub implikowanej trudnościami w samodzielnym zwalczaniu oskarżenia, wywoływanymi wagą stawianych oskarżonemu zarzutów.

Biorąc pod uwagę szeroki zakres zastosowalności, jaki w postępowaniu w przedmiocie odpowiedzialności karnej znajduje zasada paralelnego traktowania ogółu przypadków obrony obligatoryjnej, oraz istnienie tylko jednego przepisu będącego lex specialis, błędne i niezrozumiałe byłoby jakiekolwiek odstępstwo od zasady zrównania obrony obligatoryjnej przyczynowanej względami podmiotowymi i przedmiotowymi na rzecz dyferencjacji zasad udziału $\mathrm{w}$ rozprawach odbywających się $\mathrm{w}$ procedurze rehabilitacyjnej obrońcy reprezentującego małoletniego oraz oskarżonego mającego problemy z fizycznym lub psychicznym stanem zdrowia $\mathrm{z}$ uprawnieniami przysługującymi $\mathrm{w}$ tym zakresie profesjonalnemu reprezentantowi ustanawianemu z przyczyn przedmiotowych. Do osobistej obecności i rzeczywistej aktywności profesjonalnego reprezentanta rehabilitowanego oskarżonego o zbrodnię obliguje ustawa nakazująca udział obrońcy w zakresie identycznym z udziałem obrońcy obligatoryjnie reprezentującego prawne interesy oskarżonego ze względów podmiotowych. Ergo obrońca osoby oskarżonej o zbrodnię jest zobligowany do uczestnictwa $\mathrm{w}$ toku wszystkich rozpraw odbywających się $\mathrm{w}$ procedurze zmierzającej do odzyskania statusu osoby niewinnej, in toto obejmujących rozprawy przed Sądem Najwyższym w ramach szybkiej i zwyczajnej ścieżki rehabilitacji oraz $\mathrm{w}$ ponownym postępowaniu apelacyjnym lub raz jeszcze odbywającym się przed sądem in meriti.

Identyczny zakres obowiązku stawiennictwa obrońcy reprezentującego oskarżonego ze względów podmiotowych i przedmiotowych ustawa konstytuuje dwoma różnymi technikami legislacyjnymi. Vide supra, obowiązkową reprezentację interesów oskarżonego na wszystkich rozprawach odbywających się $\mathrm{w}$ procedurze rehabilitacyjnej przez profesjonalistę ustanowionego ze względu na wiek lub stan zdrowia fizycznego lub psychicznego reprezentowanego statuuje przepis ogólny, obejmujący nakaz uczestnictwa $\mathrm{w}$ rozprawach odbywających się $\mathrm{w}$ ramach modelowego i wzbogaconego toku postępowania, oraz stanowiący superfluum przepis konstytuujący zobowiązanie do stawiennictwa na rozprawie apelacyjnej, poprzez zaś jego transpozycję na grunt procedowania w trybie kasacji - 
także obowiązek udziału obrońcy w rozprawie kasacyjnej. Obowiązkową profesjonalną reprezentację rehabilitowanego oskarżonego $\mathrm{w}$ akcie oskarżenia o zbrodnię na forum ogółu rozpraw odbywających się w procedurze nakierowanej na uniewinnienie statuują natomiast trzy odrębne przepisy, żaden z nich nie dubluje zapisu zawartego w innym, ergo wszystkie trzy regulacje, nie będąc nieszkodliwą nadmiernością legislacyjną, są bezwzględnie konieczne do przyjęcia obowiązku uczestnictwa obligatoryjnego obrońcy reprezentującego oskarżonego o zbrodnię we wszystkich rozprawach odbywających się $\mathrm{w}$ procedurze rehabilitacyjnej. Pierwszą podstawę obligującą do udziału na forum rozprawy obrońcy reprezentującego oskarżonego o zbrodnię ulokowano w przepisach regulujących statykę procesu karnego, wraz z regulacjami statuującymi przesłanki przedmiotowe obligatoryjnej obrony formalnej oraz zasady jej ustanawiania (art. 80 zd. drugie k.p.k.). Zobowiązuje ona obrońcę reprezentującego interesy oskarżonego o zbrodnię do udziału w rozprawie głównej, tj. najważniejszym odcinku drogi procesu, czyli centralnym etapie stadium jurysdykcyjnego $\mathrm{w}$ modelowym pierwszoinstancyjnym przebiegu, na forum którego dokonuje się kontradyktoryjne rozpoznanie oraz rozstrzygnięcie dotyczące zasadniczego przedmiotu procesu ${ }^{78}$. Dwie kolejne normy nakazujące obrońcy interesów oskarżonego o zbrodnię udział w rozprawach to normy usytuowane w części regulującej kinetykę postępowania apelacyjnego (art. 450 § 1 k.p.k.), a poprzez jej transpozycję na grunt procedowania w trybie nadzwyczajnych środków odwoławczych - także w części regulującej kinetykę postępowania kasacyjnego (art. 450 § 1 k.p.k. w zw. z art. 518 k.p.k.). Normy obligujące obrońcę oskarżonego o zbrodnię do udziału $\mathrm{w}$ rozprawach odbywających się $\mathrm{w}$ ramach wzbogaconego toku postępowania to dokładnie te, które $\mathrm{w}$ przypadku obrony uzasadnionej względami podmiotowymi stanowią nieszkodliwy nadmiar legislacyjny. Zobowiązanie do stawiennictwa obrońcy obligatoryjnego na rozprawie apelacyjnej i kasacyjnej obejmuje bowiem swoim zakresem ogół przypadków obowiązkowej obrony formalnej, lege non distinguente przysługującej zarówno ze względów podmiotowych, jak i z przyczyn przedmiotowych - o ile jednak w przypadku obrony przyczynowanej wiekiem lub stanem zdrowia fizycznego i psychicznego stanowią one superfluum, o tyle są niezbędne dla obligatoryjnej obecności obrońcy reprezentującego interesy oskarżonego o zbrodnię.

Aktualny stan prawny, obowiązujący w zakresie obowiązkowej obecności obrońców obligatoryjnych na rozprawach odbywających się w kwestii odpowiedzialności karnej oskarżonego, jest efektem modyfikacji dotych-

${ }^{78}$ M. CIEŚLAK: Polska procedura karna. Podstawowe założenia teoretyczne. W: IDEM: Dzieła wybrane. T. 2..., s. 51. 
czasowych regulacji. Pierwotna wersja przepisów statuujących obowiązek udziału w rozprawach obrońców obligatoryjnych różnicowała reguły dedykowane obrońcom reprezentującym oskarżonego ze względów podmiotowych i przedmiotowych. O ile bowiem nakaz stawiennictwa obrońcy obligatoryjnego ustanawianego ze względów podmiotowych niezmiennie reguluje przepis ogólny (art. 79 \$ 3 k.p.k.) oraz dwie normy nadmiarowe (450 § 1 k.p.k. i art. 450 § 1 k.p.k. w zw. z art. 518 k.p.k.), o tyle do dnia 1 lipca 2015 r. istniejące verba legis zobowiązanie do obecności na rozprawie głównej obrońcy obligatoryjnego reprezentującego oskarżonego z przyczyn podmiotowych dotyczyło jedynie rozprawy głównej, zaś nałożenie nakazu stawiennictwa na rozprawie apelacyjnej i kasacyjnej pozostawiono w gestii prezesa sądu lub sądu ${ }^{79}$. Ujednolicenie reguł obowiązkowej obecności na rozprawach ogółu obrońców obligatoryjnych z pewnością

79 Nie oznacza to, że do dnia 1 lipca 2015 r. obecność obrońcy obligatoryjnego przysługującego ze względów przedmiotowych na rozprawie głównej, apelacyjnej i kasacyjnej była objęta w pełni poprawną regulacją. Wielokrotnie sygnalizowano bowiem wątpliwości dotyczące ustawowego lub tylko warunkowanego, decyzją organu procesowego, charakteru stawiennictwa na rozprawy apelacyjne i kasacyjne obrońcy przysługującego ze względu na wagę czynu. Wątpliwości te generowała kolizja pomiędzy przepisem statuującym przedmiotowe przesłanki obrony obligatoryjnej, zawierającym nakaz obecności obrońcy na rozprawie głównej oraz możliwość uznania przez prezesa sądu lub sąd jego obecności na rozprawie apelacyjnej i kasacyjnej za konieczną (art. 80 in fine k.p.k. w brzmieniu obowiązującym do dnia 1 lipca 2015 r.), a normą regulującą wprost lub za pośrednictwem przepisu odsyłającego zasady uczestnictwa wszystkich obrońców obligatoryjnych $\mathrm{w}$ rozprawie przed sądem rozpoznającym apelację i kasację (art. $450 \S 1$ k.p.k. oraz art. $450 \S 1$ k.p.k. w zw. z art. 518 k.p.k.). Obie normy kreowały obowiązek udziału obrońcy ustanawianego ze względów przedmiotowych w rozprawach odbywających się w ramach rozpoznania zwyczajnego i nadzwyczajnego środka odwoławczego - pierwsza zobowiązanie profesjonalnego reprezentanta warunkuje jednak uznaniem osobistego stawiennictwa za niezbędne przez prezesa sądu lub sądu; druga traktuje obowiązek obrońcy w sposób bezwarunkowy. Wykluczona była afirmacja tezy o dopuszczalności dyferencjacji zasad obecności na rozprawach odbywających się w ramach modelowego i wzbogaconego toku postępowania. Rzeczywiście skuteczne i logicznie poprawne rozstrzygnięcie kolizji norm wymagało powołania się na konieczność realnego zagwarantowania ochrony interesów oskarżonego. Niewątpliwie z dwóch regulacji - jednej, uzależniającej obligatoryjną reprezentację oskarżonego w toku rozpraw apelacyjnych i kasacyjnych od arbitralnej, niezaskarżalnej decyzji organu procesowego, i kolejnej, nakazującej obrońcy oskarżonego stawiennictwo na każdej rozprawie w przedmiocie zasadności zwyczajnego lub nadzwyczajnego środka odwoławczego - pewność prawidłowej, profesjonalnej reprezentacji interesów oskarżonego gwarantuje rozwiązanie przewidujące bezwarunkowe obligatoryjne uczestnictwo obrońcy w rozprawach przed sądem apelacyjnym i Sądem Najwyższym. Zob. P. Hofmański, E. SAdZIK, K. ZgrYZeK: Kodeks postępowania karnego. T. 2: Komentarz do artykułów 297-467. Red. P. HofmańsKi. Warszawa 2004, s. 688; T. GrzegorczYK: Kodeks postępowania karnego oraz ustawa o świadku koronnym..., s. 1183; D. ŚwIECKI: Rozprawa apelacyjna $w$ polskim procesie karnym..., s. 61; S. ZAвŁOcKI: Apelacja. W: Kodeks postępowania karnego. T. 3..., s. 258. 
było uzasadnione. Wysoce prawdopodobne jest bowiem to, że w trakcie każdej rozprawy odbywającej się in casu oskarżony o zbrodnię będzie miał - jak niezdolny do samodzielnej obrony ze względu na wiek lub stan zdrowia psychicznego i fizycznego - trudności w osobistym zwalczaniu tez oskarżenia, zupełnie niezwiązane ze zdolnością do samodzielnego podjęcia i wyrażenia woli. Egzemplifikacyjnie można wskazać: konieczność ustosunkowania się do $-\mathrm{z}$ założenia trudniejszych niż $\mathrm{w}$ innych sprawach - zagadnień faktycznych i prawnych, problemy z przygotowaniem się do ewentualnego - w pełni przecież merytorycznego - odwoławczego postępowania dowodowego, dostęp do literatury prawniczej i orzecznictwa mogących ułatwić aktywny udział w postępowaniach odwoławczych dotyczących czynu o największym ładunku społecznej szkodliwości itp. $\mathrm{Z}$ perspektywy realnych trudności w samodzielnym sprawowaniu obrony sytuacja oskarżonych o zbrodnię jest więc zbliżona do położenia osób mających problemy w samodzielnym zwalczaniu tez oskarżenia ze względu na stan zdrowia fizycznego i psychicznego oraz wiek - różny jest jedynie charakter trudności, jakich w samodzielnej obronie doznają obie grupy oskarżonych. Skoro $\mathrm{w}$ toku postępowania apelacyjnego i kasacyjnego sytuacja oskarżonych reprezentowanych przez obligatoryjnych obrońców ustanawianych ze względów podmiotowych i przedmiotowych jest podobna, ergo brak jest jakiegokolwiek ratio mogącego uzasadnić dyferencjację zasad obecności ogółu obrońców działających obligatoryjnie na rzecz i w imieniu oskarżonego. In effectu reguły stawiennictwa wszystkich obrońców przysługujących ze względu na trudności w samodzielnym prezentowaniu swoich interesów powinny być tożsame - a więc całkowicie niezależne od uznaniowych decyzji organów procesowych.

Uzasadniona jest również dyferencjacja technik legislacyjnych statuujących obowiązek udziału w rozprawach odbywających się w modelowym i wzbogaconym przebiegu procesu obrońcy obligatoryjnego ustanawianego z przyczyn podmiotowych i przedmiotowych. Nakaz stawiennictwa obligatoryjnego obrońcy reprezentującego oskarżonego ze względu na wiek lub niezdolność do samodzielnej i świadomej obrony materialnej na wszystkie rozprawy możliwe in casu implikuje bowiem fakt, że przesłanki podmiotowe mogą pozostawać aktualne także po uprawomocnieniu się orzeczenia. We wszystkich postępowaniach toczących się po ostatecznym zamknięciu procesu oskarżony wciąż może bowiem potrzebować profesjonalnej pomocy prawnej, ze względu na wiek, całkowite zniesienie lub znaczne ograniczenie funkcjonowania zmysłów, wątpliwości dotyczące możliwości prowadzenia obrony w sposób samodzielny i rozsądny oraz ze względu na okoliczności utrudniające obronę. W postępowaniu $\mathrm{w}$ przedmiocie wydania wyroku łącznego profesjonalna pomoc prawna może zaś okazać się niezbędna także ze względu na wątpliwości co do 
zniesienia lub ograniczenia poczytalności oskarżonego in tempore criminis, oceniane jednak wyłącznie na potrzeby tego postępowania i autonomicznie w stosunku do wcześniejszych postępowań, w których wydano wyroki podlegające łączeniu ${ }^{80}$. Wykluczyć natomiast należy, by w postępowaniu odszkodowawczym wciąż aktualna pozostawała przesłanka ustanowienia profesjonalnej pomocy prawnej, fundowana na wattpliwościach dotyczących poczytalności oskarżonego ${ }^{81}$. Podmiot dochodzący roszczeń cywilnych z tytułu niesłusznego skazania oraz niewątpliwie niesłusznego aresztowania lub zatrzymania nie zachowuje bowiem statusu oskarżonego, dochodząc odszkodowania i zadośćuczynienia, podmiot będący w przeszłości oskarżonym występuje już jako endemiczna strona postępowania odszkodowawczego, którą ustawodawca określa jako wnioskodawcę ${ }^{82}$. Tymczasem badanie sądowo-psychiatryczne może być przeprowadzone wyłącznie w stosunku do oskarżonego. Ratio obrony obligatoryjnej stanowi potrzeba zapewnienia profesjonalnej pomocy prawnej oskarżonemu mogącemu mieć problemy w prezentowaniu własnych racji, szansą na należytą - nie zaś tylko iluzoryczną - reprezentację interesów oskarżonych przez obrońców obligatoryjnych jest zaś obowiązek uczest-

80 P. Hofmański, E. SAdzIK, K. ZgryzeK: Kodeks postępowania karnego. T. 3. Komentarz do artykułów 468-682. Red. P. HofmańsKi. Warszawa 2004, s. 345; W. JasińsKi: Jawność wewnętrzna postępowania sądowego. W: Jawność procesu karnego..., s. 274; D. Kala: Obrońca $w$ postępowaniu $w$ sprawach o wydanie wyroku tącznego. Pal. 2003, z. 7-8, s. 167; D. ŚwiATŁowski: Wyrok łączny. W: Kodeks postępowania karnego. Komentarz. Red. J. Skorupka. Warszawa 2015, s. 1368. Zob. też postanowienie SN z dnia 11 września 1996 r., II KKN 69/96. „Wokanda” 1997, z. 2, s. 12.

81 W. JAsińsKI: Jawność wewnętrzna postępowania sądowego. W: Jawność procesu karnego..., s. 271; IDEM: Odszkodowanie za niestuszne skazanie, tymczasowe aresztowanie lub zatrzymanie. W: Kodeks postępowania karnego. Komentarz..., s. 556; S. STACHOWIAK: Odszkodowanie za niestuszne skazanie, tymczasowe aresztowanie lub zatrzymanie $w$ kodeksie postępowania karnego. Prok. i Pr. 1999, z. 1, s. 67; T. WoźnY: Charakter prawny postępowania o odszkodowanie za niestuszne skazanie, tymczasowe aresztowanie lub zatrzymanie. PiP 2004, z. 8, s. 66. W doktrynie funkcjonuje także stanowisko, zgodnie z którym każda osoba oskarżona w przeszłości o zbrodnię, następnie zaś dochodząca przed sądem okręgowym roszczeń z tytułu wadliwego funkcjonowania organów ścigania lub wymiaru sprawiedliwości, musi mieć w procedurze odszkodowawczej pełnomocnika. Zob. P. HofmańsKi, E. SAdzIK, K. ZgryzeK: Kodeks postępowania karnego. T. 3..., s. 317; P. Cioch: Odpowiedzialność Skarbu Państwa z tytułu niestusznego skazania. Warszawa 2007, s. 173.

82 P. Сıосн: Odpowiedzialność Skarbu Państwa z tytułu niestusznego skazania..., s. 162; A. KAFARSKI: Postępowanie $w$ sprawach o wynagrodzenie za niestuszne skazanie. PiP 1959, z. 1, s. 101; J. WASZCZYŃsKI: Odszkodowanie za niestuszne skazanie lub aresztowanie. Pal. 1974, z. 11, s. 140; C. WisŁocKI: Z zagadnień postępowania w sprawach o odszkodowanie za niestuszne skazanie lub aresztowanie (art. 510-516 k.p.k.). Pal. 1958, z. 11, s. 85. Zob. też postanowienie SA w Poznaniu z dnia 20 listopada 1990 r., II AKz 2/90, OSAiSN 1992, z. 2, poz. 16. W wyroku wyraźnie stwierdzono, że osoba wnosząca o odszkodowanie za niesłuszne skazanie jest wnioskodawcą, a reprezentujący jej interesy adwokat - pełnomocnikiem. 
nictwa $\mathrm{w}$ rozprawach profesjonalnego przedstawiciela ustanawianego dla osoby niemogącej bronić się w sposób świadomy i samodzielny. Skoro zaś podmiotowe przesłanki obrony obligatoryjnej mogą pozostawać aktualne także po uprawomocnieniu się orzeczenia, ustawodawca musiał szeroko zakreślić zakres obowiązku uczestnictwa obrońcy reprezentującego interesy oskarżonego niemogącego bronić się samodzielnie ze względów podmiotowych - tak by objąć nim uczestnictwo we wszystkich rozprawach odbywających się w czasie, gdy aktualne pozostają przesłanki podmiotowe obrony obligatoryjnej.

Równie szeroka regulacja zakresu obowiązku stawiennictwa na rozprawę obligatoryjnego obrońcy reprezentującego oskarżonego z przyczyn przedmiotowych jest zbędna. Wykluczone jest bowiem zaistnienie $\mathrm{w}$ jakimkolwiek postępowaniu odbywającym się po ostatecznym zamknięciu procesu przedmiotowej przesłanki obrony obligatoryjnej (postępowanie $\mathrm{w}$ przedmiocie wydania wyroku łącznego) lub obligatoryjnego pełnomocnictwa (postępowanie odszkodowawcze). Brak podstaw do obrony obligatoryjnej lub obligatoryjnego pełnomocnictwa, uzasadnionej pierwszoinstancyjną właściwością sądu okręgowego skumulowaną z zarzutem zbrodni, wynika z charakteru procedur toczących się po uprawomocnieniu orzeczenia. Zarówno postępowanie $w$ przedmiocie zasądzenia odszkodowania z zadośćuczynienia z tytułu błędów organów ścigania lub wymiaru sprawiedliwości, jak i postępowanie w przedmiocie wydania wyroku zaocznego kategoryzuje się jako postępowania uzupełniające, wyodrębniane w ramach tzw. postępowań dodatkowych. Nazwa „postępowania karne” obejmuje swoją ekstensją różne porządki procedowania co do poszczególnych kwestii pojawiających się w procesie karnym, tj. postępowanie, którego zasadniczym celem jest rozstrzygnięcie w przedmiocie odpowiedzialności karnej oskarżonego oraz postępowanie toczące się dla osiągnięcia celów ubocznych. Podział postępowań na zasadnicze i dodatkowe wynika więc ze stosunku poszczególnych porządków do głównego nurtu procesu. $Z$ tej perspektywy postępowania dodatkowe są grupą postępowań nakierowanych na rozstrzygnięcie innej kwestii prawnej niż odpowiedzialność karna, pozostających jednak w związku z postępowaniem zasadniczym. Postępowania uzupełniające są osobnymi postępowaniami, dołączającymi się do procesu już po jego prawomocnym zakończeniu w celu rozstrzygnięcia kwestii niezałatwionej w ostatecznie zamkniętym procesie - albo z powodu ich przeoczenia, albo ze względu na ich zaistnienie już po zakończeniu procesu ${ }^{83}$. Kwestię tę w postępowaniu odszkodowawczym stanowią roszczenia cywilne, których przesłanki

${ }^{83}$ M. CIEŚLAK: Polska procedura karna. Podstawowe założenia teoretyczne. W: IDEM: Dzieła wybrane. T. 2..., s. 58. 
zaistniały wraz z korekturą wadliwego, ale już wykonanego w całości lub części orzeczenia, z kolei w procedurze zmierzającej do wydania wyroku łącznego rozstrzygnięciu podlega kwestia zastapienia prawidłowo orzeczonych sankcji karnych, zdezaktualizowanych jednak wskutek zmiany prawnej oceny zachowania skazanego, ze względu na pojawienie się przesłanek kary łącznej konieczne staje się bowiem dopasowanie nowej kary i środków karnych do całokształtu przestępnej działalności oskarżonego.

Tymczasem przedmiotowa przesłanka obrony obligatoryjnej dotyczy sytuacji możliwej wyłącznie na gruncie postępowania w przedmiocie odpowiedzialności karnej, tylko wówczas można bowiem przyjąć, że oskarżony $\mathrm{w}$ pierwszoinstancyjnym postępowaniu staje pod zarzutem popełnienia czynu zakwalifikowanego $\mathrm{w}$ akcie oskarżenia jako zbrodni. $\mathrm{Z}$ oczywistych powodów wykluczone jest przyjęcie, że w sprawach o odszkodowanie wnioskodawcy dochodzącemu roszczeń o odszkodowanie lub zadośćuczynienie zarzucano zbrodnię, postępowanie w przedmiocie wydania wyroku łącznego toczy się zaś już po tym, jak kwestia odpowiedzialności karnej została rozstrzygnięta w wyrokach podlegających łączeniu, ergo także wówczas przedmiotem postępowania nie jest już rozpoznawanie zarzutu popełnienia jakiegokolwiek przestępstwa. Regulacja obowiązkowej obecności obrońcy obligatoryjnego ustanawianego ze względów przedmiotowych na wszystkich rozprawach odbywających się in casu nie wymagała więc formuły ogólnej, obejmującej także rozprawy toczące się po uprawomocnieniu się orzeczenia. Dla zobowiązania obrońcy obligatoryjnego reprezentującego oskarżonego o zbrodnię we wszystkich rozprawach odbywających się w czasie, gdy przedmiotowa przesłanka obrony obligatoryjnej pozostaje aktualna, wystarczające są trzy osobne regulacje dotyczące zapewnienia udziału profesjonalnego przedstawiciela na rozprawie głównej, apelacyjnej i kasacyjnej. Tak wytyczony zakres obowiązku stawiennictwa obligatoryjnego obrońcy oskarżonego ustanawianego ze względów przedmiotowych in toto obejmuje ogół rozpraw możliwych $\mathrm{w}$ sprawach toczących się $\mathrm{w}$ przedmiocie odpowiedzialności karnej za czyn kwalifikowany jako zbrodnia.

\section{Zastępcza obecność obrońcy rehabilitowanego pozbawionego wolności}

Nieco mniej restryktywnie ukształtowano zasadę jawności wewnętrznej, odnoszącej się do osobistego i faktycznego udziału profesjonalnego przedstawiciela osoby przywracanej do grona osób niekaranych, w przypadku obrony stanowiącej swoiste succedaneum nieobecności oskarżonego sygnalizującego chęć uczestnictwa w rozprawie apelacyjnej i kasacyjnej. 
Zastępczy obligatoryjny udział dotyczy obrońcy oskarżonego, wbrew swojemu wyraźnie wyartykułowanemu żądaniu niesprowadzonego na rozprawę apelacyjną z miejsca odosobnienia, w którym z jakiegokolwiek powodu przebywa na mocy decyzji uprawnionych organów (vide supra enuncjacje dotyczące dostępu rehabilitowanego przebywającego w warunkach detencji do rozpraw odbywających się w postępowaniach apelacyjnych i kasacyjnych). Sąd odwoławczy może bowiem wykluczyć osobiste uczestnictwo pozbawionego wolności, uznając jednocześnie, że jego prawny interes będzie wystarczająco reprezentowany przez obrońcę. Dotychczas i później tylko fakultatywna obrona formalna przekształca się więc w obronę obligatoryjną - ergo już ustanowiony zawodowy przedstawiciel oskarżonego, do tego momentu posiadający tylko prawo udziału w rozprawach, zostaje zobowiązany do stawiennictwa, a dla oskarżonego, do tej pory samodzielnie realizującego funkcję obrony, ustanawia się obrońcę z urzędu, równocześnie formułując nakaz jego uczestnictwa w rozprawie apelacyjnej (art. 451 k.p.k. ${ }^{84}$. W toku procedowania nad kwestią zlikwidowania skutków wadliwego wyroku skazującego zastępczy udział obligatoryjnego obrońcy obejmie rehabilitowanego przebywającego $\mathrm{w}$ warunkach pozbawienia wolności w czasie szybkiej ścieżki rehabilitacyjnej (obejmującej procedowanie przed Sądem Najwyższym jednocześnie w kwestii zasadności kasacji i w przedmiocie odpowiedzialności karnej starającego się o uniewinnienie) oraz rehabilitowanego znajdującego się $\mathrm{w}$ warunkach detencji $\mathrm{w}$ trakcie powtórnej rozprawy przed sądem apelacyjnym orzekającym $\mathrm{w}$ przedmiocie ostatecznego uwolnienia objętego procedurą rehabilitacyjną od odpowiedzialności - jeżeli mimo rzeczywistej woli uczestniczenia w rozprawie sygnalizowanej we wniosku o sprowadzenie do sądu kontrolnego Prezes Sądu Najwyższego, Sąd Najwyższy, prezes sądu odwoławczego lub sąd odwoławczy zablokowali jego osobiste uczestnictwo, decydując jednocześnie o ekwiwalentnym udziale fachowego reprezentanta.

\section{Dostęp do procedur rehabilitacyjnych obrońcy fakultatywnego}

Starający się o prawne przywrócenie do grona osób niekaranych może $\mathrm{w}$ toku wszystkich rozpraw służących analizie zasadności nadzwyczajne-

${ }^{84}$ W. JasIŃsKi: Jawność wewnętrzna postępowania sq̨dowego. W: Jawność procesu karnego..., s. 261; M.A. KarCZMARZYK, P. Rogoziński: Udziat oskarżonego pobawionego wolności na rozprawie przed sadem odwoławczym. Pal. 1997, z. 3-4, s. 33; D. ŚwIECKI: Rozprawa apelacyjna $w$ polskim procesie karnym..., s. 68 i nast.; A. WĄSEK: Prawo oskarżonego pobawionego wolności do udziału $w$ rozprawie odwoławczej. W: Środki zaskarżenia $w$ polskim procesie karnym. Ksiega pamiątkowa ku czci prof. Zbigniewa Dody. Red. A. Gaberle, S. Waltoś. Kraków 2000, s. 131. 
go środka odwoławczego, a następnie ostatecznemu uwolnieniu od odpowiedzialności, korzystać z fachowej pomocy obrońcy fakultatywnego. Reguły otwarcia poszczególnych forów poświęconych procedowaniu w przedmiocie rehabilitacji dla ustanawianego fakultatywnie profesjonalnego reprezentanta nie są jednak jednolite. Zasadą - nieuzależnioną od decyzji organów procesowych, bez względu na instancję procedującą $\mathrm{w}$ przedmiocie rehabilitacji, abstrahującą od stawiennictwa samego rehabilitowanego oraz niesprzężoną z aktualnym przebywaniem rehabilitowanego $\mathrm{w}$ warunkach detencji - pozostaje prawo udziału fakultatywnego obrońcy rehabilitowanego we wszystkich rozprawach odbywanych w procesie mającym unicestwić skutki skazania. Modyfikacje reguły są możliwe w toku rozpraw rehabilitacyjnych toczących się przed Sądem Najwyższym lub powtórnie procedującym sądem odwoławczym. Zmiany $\mathrm{w}$ zakresie funkcjonowania reguły polegają na przekształceniu uprawnienia do osobistego udziału fakultatywnego obrońcy rehabilitowanego w nakaz stawiennictwa. Odstępstwo od reguły fakultatywnego stawiennictwa dobrowolnego obrońcy rehabilitowanego dotyczy rozpraw przed Sądem Najwyższym, badającym kwestię zasadności kasacji pojedynczo lub $\mathrm{w}$ zestawieniu z zagadnieniem ostatecznego uwolnienia od odpowiedzialności za oczywiście wadliwe przypisane przestępstwo, oraz rozpraw w czasie powtórnie toczącego się postępowania odwoławczego, tym razem mającego finalnie uwolnić rzekomego sprawcę od stawianych mu błędnie zarzutów - przekształcenie prawa stawiennictwa na rozprawie kasacyjnej w obowiązek udziału leży w gestii Prezesa Sądu Najwyższego lub samego Sądu Najwyższego, uznających osobiste uczestnictwo fachowego reprezentanta za konieczne, zaś sformułowanie w tej samej sytuacji nakazu udziału w powtórnej rozprawie apelacyjnej stanowi kognicję prezesa sądu apelacyjnego lub sądu apelacyjnego (art. 450 § 2 k.p.k. oraz art. 450 § 2 k.p.k. w zw. z art. 518 k.p.k.).

\section{Dostęp do procedur rehabilitacyjnych kilku obrońców rehabilitowanego}

Wymogi zasady jawności wewnętrznej, odnoszącej się do osobistego i faktycznego udziału profesjonalnego przedstawiciela rehabilitowanego, wydają się spełnione już $\mathrm{w}$ razie stawiennictwa na rozprawie jednego z potencjalnej trójki ustanowionych z wyboru obrońców przywracanego do grona osób niekaranych. Lege non distinguente obecność tylko jednego z obrońców wystarcza, bez względu na obligatoryjny lub fakultatywny charakter obrony formalnej oraz niezależnie od tego, czy zawodowi przedstawiciele rehabilitowanego dysponują tylko prawem do udziału w rozprawie czy też 
ich stawiennictwo jest obowiązkiem - sformułowanym verba legis lub nakazanym arbitralną decyzją organu procesowego (art. 117a § 2 k.p.k.).

Prawo lub obowiązek udziału w rozprawach rehabilitacyjnych każdorazowo obejmuje wszystkich członków zespołu obrońców reprezentujących interesy osoby przywracanej do grona osób niekaranych. Ergo na sądzie spoczywa obowiązek zadbania o stworzenie im szansy stawiennictwa na rozprawy w przedmiocie zasadności kasacji, następnie zaś uniewinnienia mocodawcy - o ich terminie należy zatem prawidłowo zawiadomić komplet obrońców ustanowionych z wyboru, zaś nakaz stawiennictwa, sformułowany przez Prezesa Sądu Najwyższego, Sąd Najwyższy, prezesa sądu odwoławczego lub sąd odwoławczy, uznających osobisty udział obrońcy za konieczny, musi objąć ogół zawodowych reprezentantów rehabilitowanego. Za niedopuszczalną należy zatem uznać selekcję wśród obrońców, dokonywaną przed rozprawą przez uprawnione organy. Tym samym zarówno zawiadomienie o terminie rozprawy, jak i nakaz osobistego udziału w rozprawie nie może dotyczyć tylko niektórych członków dwuosobowego lub trzyosobowego zespołu obrońców - nawet jeżeli w toku rozprawy rehabilitacyjnej sąd zaplanował badanie wyłącznie tych okoliczności, którymi w ramach wewnętrznego podziału kompetencji pomiędzy obrońcami zajmuje się wybrany obrońca, zawiadomiony o terminie rozprawy i uprawniony do wzięcia w niej udziału, lub zobligowany do osobistego uczestnictwa fachowy reprezentant rehabilitowanego.

Co prawda ogół norm przewidujących możliwość nałożenia na zawodowego przedstawiciela rehabilitowanego nakazu stawiennictwa na rozprawę (art. 450 § 2 k.p.k., art. 451 k.p.k., art. 450 § 2 k.p.k. w zw. z art. 518 k.p.k.), określając adresata tego nakazu, posługuje się liczbą pojedynczą - używając nazwy „obrońca”, nie zaś „obrońcy”. Prima facie mogłoby to sugerować dopuszczalność objęcia obowiązkiem stawiennictwa tylko jednego z członków zespołu obrońców. Tego typu wnioskowanie jest jednak absolutnie nieuzasadnione. Pierwszy z obciążających go błędów polega na całkowitym pominięciu konwencji, w jakiej skonstruowano ogół przepisów odnoszących się do obrońcy - zasadą pozostaje, że na oznaczenie zawodowego przedstawiciela interesów oskarżonego ustawodawca używa nazwy funkcji wyrażonej w liczbie pojedynczej. Ponadto przepisy umożliwiające przekształcenie prawa w obowiązek modyfikują zasady samego przebiegu rozprawy w tym jej fragmencie, który dotyczy osobistego udziału obrońcy - ogólne przepisy regulujące udział przedstawicieli stron za wystarczające uznają zaś realne uczestnictwo tylko jednego z kilku członków zespołu obrończego lub pełnomocniczego. Ergo stawiennictwo wszystkich lub tylko niektórych z kilku ustanowionych z wyboru obrońców rehabilitowanego pozostawiono wyborowi samego rehabilitowanego i zespołu broniących go adwokatów lub radców prawnych - w większości przypadków pojedyn- 
cze lub grupowe stawiennictwo obrońców będzie determinowane strategią przyjętą w staraniach o przywrócenie do grona osób niewinnych, zwłaszcza zaś przyjętym wewnątrz zespołu podziałem obowiązków obrończych.

Stawiennictwo tylko jednego z nich - jakkolwiek verba legis wystarczające - nie może jednak generować procedowania w sposób automatyczny. Ratio instytucji obrony formalnej stanowi zagwarantowanie oskarżonemu rzeczywistego, fachowego wsparcia w zwalczaniu tez oskarżenia - efektywność wieloosobowej obrony formalnej gwarantuje zaś nie tyle obecność jakiegokolwiek z kilku ustanowionych obrońców, lecz jedynie tego z nich, który jest przygotowany do aktywnego udziału w czynnościach procesowych. Jeżeli więc zespół obrońców oskarżonego dokonał wewnętrznego podziału zadań związanych z walką o wyłączenie lub złagodzenie odpowiedzialności mocodawcy, zaś na rozprawę stawił się ten z nich, który zajmuje się obroną oskarżonego w innych kwestiach niż objęte analizą planowaną w toku rozprawy - sąd, stwierdzając brak reprezentanta zdolnego do zapewniania rzeczywistej, nie zaś tylko nominalnej obrony, powinien procedowanie przerwać lub odroczyć ${ }^{85}$. Egzemplifikacyjnie - zakładając, że rehabilitowany wraz z dwuosobowym lub trzyosobowym zespołem obrońców dokonali podziału obowiązków, przydzielając każdemu z nich starania o zwalczenie tez oskarżenia w zakresie tylko jednego z kilku czynów inkryminowanych rehabilitowanemu, stawiennictwo reprezentanta zajmującego się obroną formalną w zakresie przestępstwa innego niż objęte analiza przewidywaną w toku konkretnej rozprawy rehabilitacyjnej powinno skutkować uznaniem braku prawidłowej reprezentacji i w następstwie przerwaniem lub odroczeniem procedowania.

\section{1. § 4. Wewnętrzna jawność postępowań rehabilitacyjnych odbywających się w trybie wznowienia postępowania}

\subsubsection{Fora odbywające się w procedurze rehabilitacyjnej}

Przywrócenie do grona osób prawnie niewinnych w postępowaniu wznowieniowym z reguły odbywa się na kilku różnych forach, obejmujących analizę zasadności środka odwoławczego, następnie zaś ostateczne uwolnienie od odpowiedzialności. Szybka ścieżka rehabilitacyjna,

${ }^{85}$ Wyrok SN z dnia 17 marca 1981 r., II KR 319/79, OSNKW 1980, z. 5-6, poz. 59; W. DAszKIEWICZ: Glosa do wyroku Sądu Najwyższego z dnia 17 marca 1981 r., II KR 319/79. PiP 1982, z. 11, s. 151; E. HuzAR: Glosa do wyroku Sądu Najwyższego z dnia 17 marca 1981 r., II KR 319/79. „Orzecznictwo Sądów Polskich i Komisji Arbitrażowych” 1981, z. 9, s. 373; P. HofmańsKi, E. SAdZIK. K. ZgrYZeK: Kodeks Postępowania Karnego. T. 1..., s. 393; W. JasińsKi: Jawność wewnętrzna postępowania sq̨dowego. W: Jawność procesu karnego..., s. 246. 
obejmująca skumulowane badanie obu tych kwestii, jest możliwa tylko w wyjątkowych przypadkach. Ostateczne odzyskanie statusu boni viri jest możliwe w kilku różnych konfiguracjach procesowych:

a) posiedzenia sądu wznowieniowego, tj. Sądu Najwyższego (w razie gdy procedowanie $\mathrm{w}$ przedmiocie odpowiedzialności rehabilitowanego sfinalizowało orzeczenie Sądu Najwyższego lub sądu apelacyjnego), sądu apelacyjnego (na wypadek rehabilitacji osoby odpowiadającej w procesie zakończonym przed sądem apelacyjnym orzeczeniem skazującym, warunkowo lub bezwarunkowo umarzającym) lub sądu okręgowego (w sytuacji gdy procedowanie w przedmiocie odpowiedzialności aktualnie rehabilitowanego zakończyło się na poziomie sądu rejonowego), obejmującego najpierw 1) badanie prawdopodobieństwa zaistnienia podstawy propter nova - wyłącznie na podstawie istniejącej dokumentacji lub także w oparciu o informacje uzyskane z czynności sprawdzających, realizowanych przez sąd wznowieniowy, sąd miejscowo właściwy, sędziego wyznaczonego ze składu orzekającego lub w zakresie niewymagającym przeprowadzenia dowodów także przez referendarza sądowego, następnie zaś 2) uznanie w świetle wszystkich faktów i dowodów (lege non distinguente także nowo ujawnionych) orzeczenia skazującego ewidentnie niesłusznym i w konsekwencji następcze uniewinnienie rehabilitowanego;

b) posiedzenia sądu wznowieniowego, obejmującego wyłącznie badanie aktowe lub także - następujące $\mathrm{w}$ drodze czynności sprawdzających - badanie zaistnienia którejkolwiek z podstaw powrotu do prawomocnie sfinalizowanego postępowania oraz ponowne procedowanie $\mathrm{w}$ przedmiocie ostatecznego uwolnienia od odpowiedzialności rehabilitowanego, odbywające się po uchyleniu wyroku i następczym przekazaniu do powtórnego procedowania kwestii odpowiedzialności karnej osoby przywracanej do grona niekaranych przez sąd odwoławczy (w razie gdy wadą uzasadniającą wznowienie postępowania obciążone jest wyłącznie orzeczenie sądu kontrolnego) lub przez sąd I instancji (w sytuacji gdy brak uniewinnienia rehabilitowanego był wynikiem przestępstwa, pominięcia nieznanych w chwili orzekania faktów lub dowodów, niekonstytucyjności lub niepoprawności zastosowanych przepisów, bezwzględnych przyczyn uchylenia orzeczenia lub orzekania pod nieobecność rehabilitowanego - mających miejsce $\mathrm{w}$ postępowaniu przed sądem in meriti ${ }^{86}$. Sprzężenie wznowienia postępowania z następczym przekazaniem sprawy do ponownego

${ }^{86}$ R. KMIECIK: Formy przeprowadzania dowodu w postępowaniu o wznowienie. NP 1982, z. 3-4, s. 67; M. MANowsKA: Etapy badania skargi o wznowienie postępowania (wybrane zagadnienia). PS 2004, z. 11-12, s. 57. 
rozpoznania przed sądem pierwszoinstancyjnym powinno nastąpić w szczególności wówczas, gdy podstawą uchylenia orzeczenia są nowe fakty lub dowody, niewystarczające jednak do uruchomienia szybkiej ścieżki rehabilitacyjnej ${ }^{87}$. Cofnięcie sprawy do sądu in meriti umożliwi kontrolę instancyjną orzeczenia, które zapadnie po ponownym rozpoznaniu sprawy. En passant wspomnieć należy, że kontroli w trybie zwyczajnych środków odwoławczych podlega wyrok uniewinniający, wydany w razie niewątpliwego ustalenia w trybie szybkiej ścieżki rehabilitacyjnej, że in concreto skazano osobę rzeczywiście niewinną (art. 547 \$ 3 in fine k.p.k.). Skoro wyrok wydany w razie pewności co do niewinności oskarżonego podlega kontroli odwoławczej, a maiori ad minus sąd wznowieniowy musi zadbać o zapewnienie pełnej kontroli wyroku wydanego przez sąd in meriti, w następstwie stwierdzenia na posiedzeniu wznowieniowym wyłącznie tego, że nova mogą w sposób wiarygodny podważyć prawdziwość dotychczasowych ustaleń faktycznych - a więc wówczas, gdy sąd wznowieniowy uchyla wyrok w oparciu o nowe fakty lub dowody, nie mając pewności, czy w istocie ich uwzględnienie doprowadzi do odmiennych merytorycznie ustaleń faktycznych i, in effectu, do odmiennego orzeczenia końcowego ${ }^{88}$;

c) posiedzenia sądu wznowieniowego odbywającego się w ramach szybkiej ścieżki rehabilitacyjnej, obejmujaccej wznowienie postępowania sprzężonego z jednoczesnym uniewinnieniem osoby rzeczywiście niewinnej oraz rozprawy odbywającej się przed sądem odwoławczym w konsekwencji zaskarżenia apelacją wyroku uniewinniającego i ewentualnie rozprawy oraz posiedzenia toczące się przed Sądem Najwyższym rozpoznającym kasację od potencjonalnego wyroku sądu odwoławczego wydanego wskutek zaskarżenia wyroku uniewinniającego wydanego przez sąd wznowieniowy; ergo także wszystkie fora odbywające się w następstwie uchylenia wyroku zaskarżonego kasacją. Obrona wyroku uniewinniającego, kontestacja wyroku odwoławczego niekorzystnego dla osoby objętej procedurą rehabilitacji oraz uczestnictwo w merytorycznym sporze ponownie otwartym wskutek uwzględnienia kasacji stanowią bowiem kontynuację działań nakierowanych na przywrócenie praw osobie skazanej.

87 P. Hofmański, E. Sadzik, K. Zgryzek: Kodeks Postępowania Karnego. T. 3..., s. 270.

88 Postanowienie SN z dnia 26 września 1970 r., I KO 33/70. RPEiS 1971, z. 2, s. 30; postanowienie SN z dnia 4 sierpnia 1972 r., WP 5/72, OSNKW 1972, z. 10, poz. 165; wyrok SN z dnia 10 października 1995 r., II KO 76/94, OSNKW 1996, z. 1-2, poz. 9; postanowienie SN z dnia 24 kwietnia 1994 r., V KO 2/96, OSNKW 1996, z. 7-8, poz. 47. 


\subsubsection{Dostęp rehabilitowanego do posiedzeń i rozpraw toczących się w postępowaniu wznowieniowym i postępowaniach ponownych}

De praxis ferenda w najszerszym zakresie jawność wewnętrzną, obejmującą rzeczywistą obecność i aktywny udział na forum orzekającym $\mathrm{w}$ przedmiocie rehabilitacji najbardziej zainteresowanego unicestwieniem nieprawidłowego wyroku skazującego, ukształtowano, konstruując $\mathrm{w}$ procedurze wznowieniowej szybką ścieżkę rehabilitacyjną. Mocno skrócone postępowanie rehabilitacyjne składa się wyłącznie z etapu aktowego lub połączonego z czynnościami sprawdzającymi badania nowych faktów lub dowodów - po uznaniu zaś, że uzupełniły one dotychczasowy materiał dowodowy w sposób pozwalający na podstawie zarówno vetus, jak i nova stwierdzić ewidentność starań o przywrócenie do grona osób niekaranych $-\mathrm{z}$ następczego procedowania $\mathrm{w}$ przedmiocie uniewinnienia rehabilitowanego ${ }^{89}$. Zależnie od sposobu stwierdzenia podstaw powrotu do zakończonego skazaniem postępowania szybka ścieżka rehabilitacyjna może zatem obejmować: 1) łączne orzekanie na jednym posiedzeniu zarówno w przedmiocie zaistnienia nova, jak i w kwestii ostatecznego uwolnienia od odpowiedzialności (gdy ustalenie istnienia nowych faktów i dowodów odbywa się na podstawie dokumentów dołączonych do wniosku o wznowienie postępowania) lub 2) jednoczesne badanie obydwu tych kwestii w toku jednego posiedzenia, uzupełnione o czynności sprawdzające, odbywające się na tym samym lub wcześniejszym posiedzeniu sądu wznowieniowego, przed sądem miejscowo właściwym lub wyznaczonym ze składu sędzią (w razie niemożności ustalenia nova tylko na podstawie badań aktowych). Ze względu na to, że szybką ścieżkę rehabilitacyjną finalizuje wyrok uwalniający od odpowiedzialności, wszystkie jej etapy powinny być otwarte dla stron postępowania ${ }^{90}$ - i de lege lata tak właśnie

${ }^{89}$ M. BiŁYJ, A. MurzynowskI: Wznowienie postępowania karnego w PRL..., s. 129; J. KuIMowa: W kwestii nowych faktów lub dowodów jako podstawy wznowienia postępowania karnego. Pal. 1974, z. 10; A. KAFTAL: Wznowienie postępowania zakończonego prawomocnym orzeczeniem sq̨du wedtug nowego k.p.k. PiP 1970, z. 6, s. 921; IDEM: Niektóre zagadnienia wznowienia postępowania sqdowego. Pal. 1971, z. 7-8, s. 45; A. MurzYnowsKi: Podstawy wznowienia postępowania karnego. NP 1970, z. 7-8, s. 1007; J. NelKEN: Nowe fakty i dowody jako podstawa wznowienia postępowania sadowego. NP 1973, z. 6, s. 913; D. SzumiŁo-KulczYcKa: Prawne warunki wznowienia postępowania sqdowego. W: Środki zaskarżenia $w$ procesie karnym..., s. 231; S. ZАвŁOCKI: Wznowienie postępowania karnego $w$ świetle przepisów nowego Kodeksu postępowania karnego. W: Nowa kodyfikacja karna. Kodeks karny. Kodeks postępowania karnego. T. 16. Red. L. Bogunia. Warszawa 1998, s. 179 i nast.

90 S. ZAвњоскI: Nadzwyczajne środki odwoławcze. W: Kodeks postępowania karnego. Komentarz. T. 3..., s. 708; P. HofMAŃsKI, E. SADZIK, K. ZgRYZEK: Kodeks postępowania karnego. T. 3..., s. 253; T. GRzEgorczYK: Kodeks postępowania karnego oraz ustawa o świadku koronnym..., s. 1358; M. URbaniak: Rozpoznawanie spraw pod nieobecność oskarżonego w pol- 
kształtuje się wewnętrzna jawność skróconego postępowania rehabilitacyjnego.

Dostęp do poszczególnych fragmentów zapewnia rehabilitowanemu wyraźny zapis ustawy bądź też arbitralna decyzja prezesa sądu wznowieniowego lub sądu wznowieniowego. I tak, verba legis podejmującego starania o przywrócenie do grona osób niekaranych wyposażono w bezwzględne prawo uczestnictwa w czynnościach sprawdzających prawdopodobieństwo zaistnienia podstawy powrotu do już zamkniętego procesu oraz ewentualnie podstaw do merytorycznego zakończenia sprawy wyrokiem uniewinniającym. Dostęp rehabilitowanego do sprawdzenia okoliczności faktycznych ma charakter bezwzględny, niezależnie od sformalizowanego lub swobodnego sposobu dowodzenia podstawy wznowienia i bez względu na organ dokonujący sprawdzenia możliwości uchylenia wyroku skazującego (art. 546 k.p.k. w zw. z art. 97 k.p.k.). Bezwzględne prawo udziału w posiedzeniu wyznaczonym dla przeprowadzenia czynności sprawdzających oznacza, że decyzja o wzięciu udziału w posiedzeniu stanowi uprawnienie stron, zaś by to stawiennictwo umożliwić, obowiązkiem przeprowadzającego czynności sądu lub sędziego jest zawiadomienie stron o jego terminie i miejscu. Prawo do wzięcia udziału w czynnościach sprawdzających obejmuje ogół konfiguracji, w których dopuszcza się sprawdzenie okoliczności uzasadniających wznowienie postępowania, ergo sprawdzenie okoliczności faktycznych dokonuje się z fakultatywnym udziałem rehabilitowanego zarówno wówczas, gdy sprawdzeń dokonuje sąd wznowieniowy, sędzia wyznaczony ze składu, sąd wezwany, jak i w sytuacji dokonywania ich przez referendarza sądowego w zakresie niewymagającym przeprowadzenia dowodów.

Obecność i rzeczywistą aktywność rehabilitowanego na posiedzeniach sądów wznowieniowych orzekających ostatecznie w przedmiocie zaistnienia nova, jak i w kwestii ostatecznego uwolnienia od odpowiedzialności uzależniono od decyzji prezesa sądu lub sądu. Otwarcie szybkiej ścieżki rehabilitacyjnej ma charakter arbitralny - co do zasady bowiem forum poświęcone analizie zaistnienia prawdopodobieństwa podstaw wznowienia postępowania jest całkowicie wewnętrznie niejawne, dostęp do procedowania warunkuje dopiero decyzja organów procesowych (art. 544 $\S 3$ k.p.k.). Rozstrzyganie w przedmiocie ostatecznego uwolnienia od odpowiedzialności stanowi jednak okoliczność, która powinna obligować czynniki sądowe do przekształcenia posiedzenia o charakterze w pełni zamkniętym $\mathrm{w}$ forum przebiegające $\mathrm{z}$ udziałem zwolenników uniewinnienia i argumentujących na rzecz tez oskarżenia. Wewnętrzna jawność powsta-

skim procesie karnym..., s. 190; S. ZАвєOскI: Nowela k.p.k. z dnia 20 lipca 2000. Warszawa 2000, s. 291. 
jąca wskutek przekwalifikowania posiedzenia zupełnie niejawnego może mieć słabszy lub silniejszy charakter - wydaje się bowiem, że czynniki sądowe, zmieniając charakter posiedzenia, mogą go bądź to otworzyć, pozostawiając decyzję $\mathrm{w}$ przedmiocie osobistego stawiennictwa stronom, bądź też sformułować nakaz stawiennictwa adresowany do wskazanych procesowych zwolenników lub przeciwników rehabilitacji. Normę umożliwiającą przekształcenie forum z zupełnie zamkniętego $\mathrm{w}$ otwarte dla stron skonstruowano jako zasadę, statuując niejawność (art. 544 § 3 in principio k.p.k.), następnie zaś uprawniając wskazane czynniki sądowe do podjęcia innej decyzji (art. $544 \$ 3$ in fine k.p.k.). Konstruując zezwolenie do zmiany charakteru posiedzenia wznowieniowego, zrezygnowano natomiast z konwencji praktykowanej w pozostałych przepisach upoważniających do zmiany zasad dotyczących stawiennictwa stron - przepis nie zawiera bowiem żadnych sformułowań wskazujących na fakultatywny lub obligatoryjny charakter udziału umożliwionego lub nakazanego arbitralną decyzją organu. Egzemplifikacyjnie - norma zezwalająca na zmodyfikowanie zasad wewnętrznej jawności posiedzenia wznowieniowego nie zawiera przymiotnika określającego jako obowiązkowe stawiennictwo wynikające z zobowiązującej decyzji organu (np. sformułowania „udział jest obowiązkowy, jeżeli prezes sądu lub sąd tak zarządzi”, wzorowanego na zapisach art. $341 \S 1$ in fine k.p.k., art. $343 \S 5$ in fine k.p.k.), nie umieszczono w niej też żadnych przesłanek decyzji otwierającej posiedzenie wznowieniowe, mogących zawierać zwroty konstruujące obowiązek (np. zapisu ,prezes sądu lub sąd uzna udział za konieczny”, analogicznego do regulacji art. 450 \$ 2 in fine k.p.k., art. 535 \$ 2 k.p.k.). Skoro pozostałe normy określające zależne od organów sądowych modyfikacje jawności wewnętrznej zawierają sformułowania wskazujące na charakter osobistego stawiennictwa stron, pozbawiona jest ich zaś norma dotycząca jawności forum wznowieniowego - statuująca uprawnienie do decydowania o ukształtowaniu jawności wewnętrznej inaczej niż w przypadku procedowania bez udziału stron - jawne posiedzenie wznowieniowe może odbywać się tylko z fakultatywnym lub nawet obligatoryjnym udziałem zwolenników lub przeciwników rehabilitacji.

Jawność wewnętrzna typowego postępowania rehabilitacyjnego odbywającego się $w$ trybie wznowienia postępowania, tj. osobno toczących się procedur $\mathrm{w}$ przedmiocie powrotu do postępowania już zakończonego prawomocnym orzeczeniem skazującym, warunkowo lub bezwarunkowo umarzającym, oraz w przedmiocie ostatecznego uwolnienia od odpowiedzialności za zarzucone przestępstwo, ma charakter kombinowany. Zamknięcie lub otwarcie procedowania wobec rehabilitowanego $\mathrm{w}$ poszczególnych etapach regulują przepisy identyczne z normującymi odpowiednio szybką ścieżkę rehabilitacyjną oraz ponownie toczące się postę- 
powanie co do istoty sprawy. Vide supra, zasadniczo całkowicie zamknięte dla wszystkich zainteresowanych rehabilitacją pozostaje procedowanie we fragmencie obejmującym orzekanie na posiedzeniu o istnieniu podstaw wznowienia, otwarte są zaś procedury obejmujące ponowne badanie kwestii odpowiedzialności karnej rehabilitowanego na rozprawach przed sądem odwoławczym lub sądem in meriti. Wyjątkowe elementy jawności wewnętrznej procedowania w przedmiocie wznowienia mogą mieć charakter bezwarunkowy lub warunkowy - który to podział krzyżuje się z obligatoryjnym lub fakultatywnym charakterem stawiennictwa rehabilitowanego. Bezwarunkowość dostępu oznacza, że stawiennictwo rehabilitowanego nie jest warunkowane decyzją czynnika sądowego, decyzja o wzięciu udziału stanowi wyłączne prawo strony, ergo stawiennictwo na posiedzeniu ma charakter fakultatywny. Z kolei warunkowa jawność wewnętrzna posiedzenia w przedmiocie wznowienia postępowania jest uzależniona od decyzji prezesa sądu lub sądu wznowieniowego, przekształcającej posiedzenie niejawne wewnętrznie w forum odbywające się z fakultatywnym lub obligatoryjnym udziałem stron.

Bezwarunkowy i jednocześnie fakultatywny charakter mają czynności sprawdzające zaistnienie prawdopodobieństwa podstaw wznowienia, czynności te są konieczne w razie niemożności ustalenia podstaw wznowienia tylko w oparciu o badania aktowe. Posiedzenie w przedmiocie sprawdzenia okoliczności faktycznych jest otwarte dla stron w sposób bezwzględny. Vide supra, oznacza to, że podejmujący starania o przywrócenie do grona osób niekaranych, prawidłowo powiadomiony o miejscu i terminie posiedzenia, autonomicznie decyduje o wzięciu udziału w sprawdzeniu okoliczności faktycznych uzasadniających prawdopodobieństwo zaistnienia podstawy powrotu do już zamkniętego procesu. Z kolei udział rehabilitowanego $\mathrm{w}$ posiedzeniu wznowieniowym ma charakter fakultatywny lub obligatoryjny, w każdym jednak przypadku jednocześnie warunkowy, tj. uzależniony od arbitralnej decyzji prezesa sądu lub sądu, uprawniających lub zobowiązujących najbardziej zainteresowanego do udziału w forum sądowym. Przekształcenie posiedzenia wznowieniowego, odbywającego się w ramach typowego postępowania rehabilitacyjnego, z zupełnie zamkniętego w otwarte powinno nastąpić w szczególności, gdy istnienie podstaw wznowienia non est clara, konieczne jest więc uzupełniające przedstawienie argumentów procesowych zwolenników lub przeciwników powrotu do zakończonego prawomocnie postępowania i uniewinnienia rehabilitowanego lub ich ustosunkowanie się do rezultatu uprzednio przeprowadzonych czynności sprawdzających ${ }^{91}$. Stopień

91 S. Zавњоcкі: Nadzwyczajne środki odwoławcze. W: Kodeks postępowania karnego. Komentarz. T. 3..., s. 706; P. HofmańsKi, E. SADZIK, K. ZgryZEK: Kodeks postępowania kar- 
jawności wewnętrznej względem rehabilitowanego ponownych procedur co do istoty sprawy także może być zróżnicowany - słabszy w razie tylko fakultatywnego stawiennictwa, mocniejszy - gdy obecność starającego się o powrót do grona osób formalnie niewinnych jest obligatoryjny.

Zasady udziału rehabilitowanego w ponownie odbywającej się rozprawie odwoławczej lub rozprawie głównej, odbywających się po uchyleniu wyroku, są identyczne jak w sytuacji, gdy procedura rehabilitacyjna przebiega w trybie kasacji, ta zaś odbywa się w postępowaniu odwoławczym lub przed sądem in meriti, zgodnie z przepisami dotyczącymi rozprawy odwoławczej i głównej. Te same reguły będą obowiązywały wówczas, gdy wskutek zaskarżenia wyroku uniewinniającego, wydanego w ramach szybkiej ścieżki rehabilitacyjnej na posiedzeniu wznowieniowym, odbywać się będzie rozprawa apelacyjna, ewentualnie także rozprawa kasacyjna i kolejne rozprawy odbywające się po uchyleniu wyroku zaskarżonego kasacją. In effectu zasadą pozostaje wyposażenie rehabilitowanego $\mathrm{w}$ prawo osobistego stawiennictwa i rzeczywistej aktywności w czasie powtórnej rozprawy odwoławczej oraz równie fakultatywny udział w postępowaniu raz jeszcze odbywającym się przed sądem in meriti, tym razem mającym finalnie potwierdzić jego niewinność. Zasadą pozostaje także prawo osobistego udziału oskarżonego w rozprawach toczących się wskutek zaskarżenia apelacją wyroku uniewinniającego i niejawność szybkiej ścieżki rehabilitacyjnej w razie zaskarżenia kasacją wyroku sądu odwoławczego niekorzystnego dla procesowych interesów oskarżonego objętego procedurą rehabilitacyjną. Zasada dotycząca jawności wewnętrznej wobec rehabilitowanego przez sąd II lub I instancji może być zmodyfikowana bądź verba legis, bądź też arbitralną decyzją prezesa sądu lub sądu odwoławczego, przewodniczącego lub sądu in meriti oraz Prezesa Sądu Najwyższego lub Sądu Najwyższego rozpoznającego potencjalną kasację wniesioną od wyroku sądu odwoławczego, wydanego wskutek zaskarżenia wyroku rehabilitującego oskarżonego w ramach szybkiej ścieżki rehabilitacyjnej. Ekstraordynaryjne rozwiązania w zakresie osobistego stawiennictwa przywracanego do kategorii osób niewinnych mogą istniejącą regułę poszerzyć lub zawęzić. Jawność wewnętrzna, mocniejsza w stosunku do reguły, dotyczy przypadków obowiązkowego stawiennictwa przewidzianego ex lege, we fragmentach rozprawy o zbrodnię, lub istniejącego ex institutio, na podstawie decyzji prezesa sądu lub sądu odwoławczego, przewodniczącego lub sądu in meriti oraz Prezesa Sądu Najwyższego lub Sądu Najwyższego. Wyjątki ograniczające regułę umożliwiają procedo-

nego. T. 3..., s. 253; T. GRzegorczyK: Kodeks postępowania karnego oraz ustawa o świadku koronnym..., s. 1358; M. URBANIAK: Rozpoznawanie spraw pod nieobecność oskarżonego $w$ polskim procesie karnym..., s. 190. 
wanie absente reo przed sądem odwoławczym ponownie orzekającym $\mathrm{w}$ sprawie osoby rehabilitowanej wbrew wnioskowi niesprowadzonej na rozprawę z miejsca pozbawienia wolności, ekwiwalentnie reprezentowanej w jej toku przez obligatoryjnego obrońcę zobowiązanego do osobistego udziału w postępowaniu.

\subsubsection{Dostęp obrońcy rehabilitowanego do posiedzeń i rozpraw toczących się w postępowaniu wznowieniowym i postępowaniach ponownych}

Kombinacje niejawności i całkowitego otwarcia procedury rehabilitacyjnej w wersji słabszej (przewidującej prawo stawiennictwa) i silniejszej (nakazującej osobisty udział) dotyczą również profesjonalnego reprezentanta osoby starającej się $\mathrm{w}$ ramach instytucji wznowienia postępowania o unicestwienie skutków skazania lub bezwarunkowego umorzenia procesu - liczbę możliwych reguł stawiennictwa różnicuje ponadto obligatoryjny lub fakultatywny charakter obrony formalnej. Bez względu na fakultatywny lub obligatoryjny charakter profesjonalnej obrony oraz sposób ustanowienia zawodowego reprezentanta zasadą jest otwarcie dla obrońcy posiedzeń odbywających się w celu sprawdzenia okoliczności faktycznych, uzasadniających wznowienie, oraz całkowite zamknięcie dla wszystkich obrońców szybkiej ścieżki rehabilitacyjnej, niewymagającej czynności sprawdzającej oraz fragmentu typowej ścieżki rehabilitacyjnej, obejmującej badanie na posiedzeniu prawdopodobieństwa zaistnienia podstaw wznowienia postępowania.

Otwarcie i tej części procedury rehabilitacyjnej dla obrońców rehabilitowanego dokonuje się, identycznie jak w przypadku rehabilitowanego, decyzją prezesa sądu lub sądu wznowieniowego. Paralelnie z regulacją otwierająca posiedzenia dla rehabilitowanego ustanowiony ex institutio dostęp jego obrońcy może mieć charakter obligatoryjny lub fakultatywny. Decyzje w przedmiocie otwarcia posiedzenia dla obrońcy oskarżonego na pewno powinny być sprzężone $\mathrm{z}$ ustanowionym ex institutio prawem udziału oskarżonego, tak by oskarżony legitymowany do udziału w forum sądowym mógł w nim uczestniczyć $\mathrm{z}$ - także tylko uprawnionym do udziału - obrońcą, już reprezentującym interesy oskarżonego lub ustanowionym później. Podobna zależność nie dotyczy obligatoryjnego udziału oskarżonego i obrońcy, z oczywistych względów prezes sądu lub sąd nie mogą bowiem wydać decyzji zobowiązującej do udziału w posiedzeniu wznowieniowym jednocześnie oskarżonego i jego obrońcy wówczas, gdy oskarżony nie korzysta z profesjonalnej pomocy prawnej. Gdyby bezwzględnie automatycznym skutkiem zobowiązania oskarżonego do sta- 
wiennictwa na posiedzenie wznowieniowe był nakaz udziału w posiedzeniu jego obrońcy, decyzja czynnika sądowego kreowałaby obowiązek ustanowienia obrońcy. Sprzężenie obowiązku udziału oskarżonego i jego obrońcy nie jest jednak automatyczne także wówczas, gdy oskarżony już korzysta z profesjonalnej pomocy prawnej, lege non distinguente obligatoryjnej ze względów podmiotowych lub przedmiotowych albo pomocy tylko fakultatywnej. Automatyczne powiązanie obowiązkowego udziału $\mathrm{w}$ forum posiedzeniowym oskarżonego i jego obrońcy pozbawiałoby bowiem jakiegokolwiek znaczenia art. 79 \$3 in fine k.p.k. Przepis ten ogranicza bowiem obligatoryjny udział obrońcy oskarżonego w posiedzeniach do tych tylko przypadków, w których obrońcę ustanowiono dla oskarżonego ze względów podmiotowych, jednocześnie zaś oskarżony niemogący samodzielnie reprezentować swoich interesów ze względu na wiek lub stan zdrowia ma obowiązek udziału na forum posiedzeniowym. Konstruując przepisy sprzęgające obowiązek stawiennictwa oskarżonego i obrońcy obligatoryjnego ze względów podmiotowych, zrezygnowano z jakiejkolwiek jego dyferencjacji według kryterium odwołującego się do źródła obowiązkowego udziału oskarżonego w forum posiedzeniowym. Ergo obowiązkowy udział obrońcy w posiedzeniu dotyczy zarówno tych przypadków, w których oskarżony zobowiązany jest do uczestnictwa ex lege, jak i tych, w których to czynnik sądowy uznał jego udział za niezbędny ${ }^{92}$. O ile więc decyzja prezesa sądu lub sądu przekształcająca całkowicie niejawne posiedzenie wznowieniowe $\mathrm{w}$ forum obligatoryjnie lub fakultatywnie otwarte dla rehabilitowanego nie jest prawnie uwarunkowana, o tyle decyzja o udziale w posiedzeniu wznowieniowym obrońcy reprezentującego oskarżonego ze względu na jego wiek albo kondycję fizyczną lub psychiczną musi zobowiązać go do stawiennictwa, wówczas gdy czynnik sądowy uprzednio zobligował do udziału na forum posiedzeniowym oskarżonego reprezentowanego przez tego adwokata lub radcę prawnego. Skoro przewidziane verba legis automatyczne sprzężenie obowiązku stawiennictwa oskarżonego i jego obrońcy na forum posiedzeniowe dotyczy wyłącznie jednej partykularnej sytuacji, we wszystkich pozostałych sytuacjach obligatoryjnego lub fakultatywnego udziału $\mathrm{w}$ posiedzeniu oskarżonego już reprezentowanego przez adwokata lub radcę prawnego stawiennictwo na posiedzenie profesjonalnego reprezentanta interesów oskarżonego ma charakter wyłącznie fakultatywny. Lege non distinguente brak obowiązku stawiennictwa obrońcy na posiedzeniu dotyczy zarówno sytuacji, gdy obrona formalna jest obligatoryjna ze względów podmiotowych, jak i przypadków korzystania przez oskarżonego z fakultatywnej

92 P. HofmańsKi, E. SADZIK, K. ZgryZeK: Kodeks postępowania karnego. T. 1. Komentarz do art. 1-296..., s. 405. 
profesjonalnej pomocy prawnej. Stanowisko to uzasadnia sygnalizowana już dyferencjacja technik legislacyjnych statuujących obowiązkową obecność na forach sądowych obrońcy obligatoryjnego ustanawianego ze względów podmiotowych i przedmiotowych. Nakaz udziału obrońcy reprezentującego interesy oskarżonego ze względu na wiek albo kondycję fizyczną lub psychiczną jest lokowany w tym samym przepisie, który statuuje obowiązkową reprezentację interesów oskarżonego na wszystkich możliwych rozprawach odbywających się w danej sprawie (art. 79 §3 in principio k.p.k.). Ustawodawca zrezygnował natomiast z jakiejkolwiek podobnej regulacji dotyczącej uczestnictwa $\mathrm{w}$ posiedzeniach obligatoryjnego obrońcy oskarżonego o zbrodnię. Trzy odrębne przepisy regulujące obowiązek stawiennictwa obligatoryjnego obrońcy ustanawianego ze względów przedmiotowych ograniczają obowiązkowy udział obrońcy reprezentującego oskarżonego o zbrodnię do forum rozprawy głównej, apelacyjnej i kasacyjnej. Ergo w pozostałych forach otwartych dla oskarżonego obligatoryjnie, względnie lub bezwzględnie, uczestnictwo reprezentującego go adwokata lub radcy prawnego ma jedynie fakultatywny charakter. Podobnie jak w przypadku rehabilitowanego, zasadniczym kryterium otwarcia posiedzenia dla obrońcy pozostaje potrzeba pozyskania informacji uzasadniających podstawę de novis. Na przekształcenie zamkniętego posiedzenia wznowieniowego $\mathrm{w}$ forum otwarte dla obrońcy nie powinien natomiast rzutować obligatoryjny lub fakultatywny charakter obrony formalnej. Jeżeli wiarygodność nova nie budzi wątpliwości, a także wówczas, gdy w ich świetle bezsporne jest, że in concreto rzeczywiście skazano osobę niewinną, w związku z czym nie istnieje potrzeba dokonywania jakichkolwiek ustaleń dotyczących okoliczności sprawy i winy sprawcy, posiedzenie powinno pozostać zamknięte, lege non distinguente zarówno wówczas, gdy formalna obrona ma charakter fakultatywny, jak i w sytuacji obowiązku reprezentowania interesów oskarżonego przez profesjonalnego przedstawiciela.

Dostęp obrońcy oskarżonego znajdującego się w procedurze rehabilitacyjnej do wszystkich pozostałych forów koniecznych dla przywrócenia oskarżonego do kategorii prawnie niewinnych zasadniczo kształtuje się paralelnie z zasadami udziału obrońcy w postępowaniu odwoławczym (gdy w następstwie wznowienia postępowania przekazano sprawę do ponownego rozpoznania przez sąd odwoławczy, zaskarżono apelacją wyrok uniewinniający wydany w ramach szybkiej ścieżki rehabilitacyjnej albo sprawa trafiła do sądu odwoławczego wskutek uwzględnienia kasacji wniesionej od wyroku sądu odwoławczego wydanego wskutek zaskarżenia apelacją wyroku uniewinniającego wydanego w ramach szybkiej ścieżki rehabilitacyjnej), postępowaniu przed sądem in meriti (w sytuacji, w której po uchyleniu orzeczenia w trybie wznowieniowym nastąpiło 
przekazanie sprawy do sądu pierwszoinstancyjnego albo ponowne postępowanie przed sądem in meriti odbywa się po uchyleniu w trybie kasacji wyroku sądu odwoławczego zapadłego w następstwie apelacji od wyroku uniewinniającego wydanego na posiedzeniu wznowieniowym) lub $\mathrm{w}$ postępowaniu kasacyjnym ( $\mathrm{w}$ razie zaskarżenia kasacją wyroku sądu odwoławczego wydanego po zaskarżeniu uniewinniającego wyroku sądu odwoławczego).

\section{2. § 4. Wewnętrzna jawność postępowań rehabilitacyjnych odbywających się w trybie stwierdzenia nieważności orzeczenia wydanego wobec osób represjonowanych za działalność na rzecz niepodległego bytu Państwa Polskiego}

Forum właściwym dla przeprowadzenia postępowania w przedmiocie stwierdzenia nieważności orzeczeń represjonujących działaczy opozycyjnych stanowi posiedzenie (art. 3 ust. 2 in principio ustawy rehabilitacyjnej). Dokonany przez ustawodawcę wybór forum stanowiącego miejsce rozstrzygania w przedmiocie wniosku o stwierdzenie nieważności stanowi konsekwencję posłużenia się formą instytucji bezwzględnej nieważności orzeczeń dla zrehabilitowania przeciwstawiających się reżimowi komunistycznemu. W okresach funkcjonowania w polskiej procedurze karnej instytucji bezwzględnej nieważności orzeczeń deklaratywne stwierdzenie nieważności dokonywało się na forum posiedzeniowym. Posiedzenie stanowi zatem tradycyjne forum dla procedowania w przedmiocie stwierdzenia nieważności - już na gruncie k.p.k. z 1928 r. zasadą było orzekanie na posiedzeniu niejawnym nakierowanym na deklaratywne potwierdzenie istnienia wady kreującej nieważność; posiedzenie jako forum dla rozpoznania kwestii nieważności przewidywał również art. 102 § k.p.k., regulujący zasady orzekania $\mathrm{w}$ przedmiocie stwierdzenia nieważności orzeczeń w dość krótkim interwale czasowym funkcjonowania instytucji nieważności bezwzględnej na podstawie k.p.k. z 1997 r., tj. do dnia 1 lipca 2003 r. Posiedzenie w przedmiocie stwierdzenia nieważności orzeczenia wydanego wobec opozycjonistów represjonowanych za działalność niepodległościową odbywa się według autonomicznych przepisów regulujących zasady jawności wewnętrznej. Tym samym nie znajduje zastosowania przepis art. $96 \S 1$ i $\$ 2$ k.p.k., będący lex generalis w zakresie udziału na posiedzeniu stron. Deroguje go bowiem art. 3 ust. 4 Ustawy z dnia 23 lutego 1991 r. o uznaniu za nieważne orzeczeń wydanych wobec osób represjonowanych za działalność na rzecz niepodległego bytu Państwa Polskiego. Zgodnie z jego treścią posiedzenie rehabilitacyjne zasadniczo pozostaje otwarte dla osoby represjonowanej oraz osoby uprawnionej do 
składania na jej korzyść środków odwoławczych. Bez względu na wiek i stan zdrowia, działacz opozycyjny jest zawsze uprawniony do samodzielnego podejmowania wszelkich czynności w toku postępowania rehabilitacyjnego. Przysługujące mu uprawnienia może wykonywać osobiście bądź też - w przypadku gdy chce skorzystać z pomocy osoby zawodowo przygotowanej do występowania przed sądem lub gdy obligują go do tego obowiązujące przepisy - za pośrednictwem obrońcy ${ }^{93}$. Na podstawie klauzuli odsyłającej do k.p.k., zawartej w art. 3 ust. 4 ustawy z dnia 23 lutego 1991 r., kwestię reprezentacji działacza opozycyjnego regulują bowiem normy procedury karnej. Wydaje się, że z ogółu norm regulujących obronę obowiązkową na grunt postępowania rehabilitującego represjonowanych działaczy opozycji należy przetransponować jedynie przepisy art. $79 \S 1$ i § 2 k.p.k., normujące podmiotowe przesłanki formalnej obrony obligatoryjnej. Ponieważ przedmiotem postępowania rehabilitacyjnego jest stwierdzenie nieważności represjonującego orzeczenia, w jego toku nie mogą się zaktualizować przesłanki obrony obligatoryjnej ustanawianej ze względu na zarzut zbrodni (art. 80 k.p.k.). Podmiotem uprawnionym do składania środków odwoławczych na korzyść rehabilitowanego, ergo - podmiotem uprawnionym do uczestnictwa w posiedzeniu rehabilitacyjnym, jest zatem jego obrońca. Procedura stwierdzania nieważności orzeczeń represjonujących działaczy niepodległościowych przewiduje też zastępczą obecność innych podmiotów. W razie gdy oskarżony nie żyje, jest nieobecny w kraju lub choruje psychicznie, ustawodawca unormował swoiste succedaneum zamiast represjonowanego niemogącego brać udziału w posiedzeniu rehabilitacyjnym jego procesowe interesy może $\mathrm{w}$ trakcie posiedzenia reprezentować krewny w linii prostej, przysposabiający lub przysposobiony, rodzeństwo oraz małżonek osoby represjonowanej. Teoretycznie kwestia wzajemnych relacji pomiędzy uprawnionymi do reprezentacji osoby rehabilitowanej może być rozwiązana na trzy różne sposoby: pierwszy zakłada konieczność łącznego wykonywania czynności przez wszystkie podmioty uprawnione do podejmowania czynności na rzecz represjonowanego, zgodnie z drugim prawo wykonywania reprezentacji represjonowanego przysługuje wyłącznie jednej z generalnie uprawnionych osób, natomiast w ostatnim z możliwych sposobów przyjmuje się, że każdy z uprawnionych ma kompetencję do samodzielnej reprezentacji represjonowanego; niewykluczone jest jednak działanie łączne kilku z nich. Odrzucenie dwóch pierwszych propozycji nie nastręcza większych trudności. Reprezentacja łączna stanowiłaby wyjątkowy przykład rozwiązania kwestii reprezento-

${ }_{93}$ Zob. postanowienie SN z dnia 6 marca 1997 r., IV KKN 78/96. Prok. i Pr. 1998, z. 5 , poz. 15 . 
wania jednego podmiotu przez kilka innych ${ }^{94}$, implikując sporo problemów związanych z odnalezieniem wszystkich reprezentantów oraz ustaleniem reguł postępowania $\mathrm{w}$ razie niezgodności pomiędzy uprawnionymi do reprezentacji interesów działacza niepodległościowego. Z kolei konstrukcja zakładająca reprezentację przez pierwszą z osób podejmujących działanie na rzecz zastępowanego jest zarezerwowana dla strony nowej lub zastępczej, tj. podmiotu przejmującego uprawnienia zmarłego pokrzywdzonego ${ }^{95}$. Z procesowym statusem represjonowanego koreluje jedynie koncepcja uprawniająca wszystkich reprezentantów do samodzielnego zastępowania represjonowanego. Wielość podmiotów wykonujących uprawnienia oskarżonego nie stanowi żadnego procesowego novum - dość wspomnieć, że oskarżony może mieć jednocześnie trzech obrońców z wyboru. Należy zatem przyjąć, że osoby generalnie uprawnione do wykonywania czynności na rzecz działacza niepodległościowego mają kompetencję do wspólnego reprezentowania jego interesów w toku procedury rehabilitacyjnej, w tym także na forum orzekającym $\mathrm{w}$ przedmiocie stwierdzenia nieważności represjonującego orzeczenia ${ }^{96}$. Dostęp rehabilitowanego, osób uprawnionych do składania na jego korzyść środków odwoławczych oraz osób reprezentujących interesy nieobecnego działacza opozycji ma charakter bezwzględny. Decyzja o osobistym uczestnictwie w posiedzeniu rehabilitacyjnym leży zatem w gestii uprawnionych, zaś dla umożliwienia im skorzystania ze swojego prawa sąd orzekający w przedmiocie wznowienia ma obowiązek zawiadomienia uprawnionych o miejscu i terminie posiedzenia rehabilitacyjnego. Zasada fakultatywnego udziału w posiedzeniu rehabilitacyjnym nie podlega ani poszerzeniu, ani zawężeniu. Czynnik sądowy nie może zatem podjąć decyzji obligującej do stawiennictwa rehabilitowanego, jego obrońcy lub podmioty reprezentujące interesy działacza opozycyjnego niemogącego działać osobiście. Wykluczone jest również orzekanie $\mathrm{w}$ przedmiocie nieważności represjonującego orzeczenia absente reo, wbrew woli uczestnictwa w posiedzeniu rehabilitacyjnym wyrażanej przez niestającego i usprawiedliwiającego swoje niestawiennictwo działacza niepodległościowego połączone $\mathrm{z}$ uznaniem, że $\mathrm{w}$ toku posiedzenia jego interesy będą wystarczająco reprezentowane przez obrońcę lub działających zastępczo krewnych w linii prostej, osób pozostających z represjonowanym w stosunku przysposobienia, jego rodzeństwa lub małżonka. Reprezentację zastępczą implikuje bowiem nieobecność represjonowanego

94 Ta konstrukcja jest obca nawet prawu cywilnemu, zgodnie bowiem z art. $98 \S 1$ k.r.o. każdy z rodziców będących przedstawicielami ustawowymi dziecka pozostającego pod ich władzą rodzicielską może działać w tym charakterze samodzielnie.

95 T. GrZEgorczYK: Kodeks postępowania karnego oraz ustawa o świadku koronnym..., s. 218.

${ }^{96}$ K. Sychta: Rehabilitacja osób represjonowanych w latach 1944-1956..., s. 115. 
powodowana trzema enumeratywnie wyliczonymi okolicznościami. Ratio zastępczej reprezentacji stanowi zastąpienie działacza niepodległościowego niemogącego stawić się z przyczyny obiektywnej (śmierć), niemogącego brać udziału w posiedzeniu ze względu na związane z tym trudności (nieobecność w kraju) lub niemogącego samodzielnie uczestniczyć w posiedzeniu ze względu na stan zdrowia psychicznego (choroba psychiczna). Instytucja skonstruowana dla skuteczniejszego reprezentowania racji działacza opozycyjnego nie może posłużyć do ograniczania uprawnień represjonowanego mogącego działać samodzielnie.

\subsection{Dostęp oskarżonego i jego obrońcy do forów odbywających się w procedurach rehabilitacyjnych - rekapitulacja}

Droga procesowa nakierowana na unicestwienie sankcji karnych utraconych na podstawie prawomocnego wyroku sądowego - w konsekwencji zaś odzyskanie przez skazanego statusu osoby niekaranej - odbywa się w trybie nadzwyczajnych środków odwoławczych inicjowanych wnioskiem skazanego lub osób uprawnionych do działania na jego korzyść. Sędziowską decyzję o unicestwieniu wszelkich skutków skazania warunkuje stwierdzenie in casu zaistnienia abstrakcyjnie i generalnie określonych ustawą przesłanek rehabilitacji. De lege lata zależnie od przesłanek rehabilitacji sądowej lub ustawowo-sądowej uzyskanie wyroku uniewinniającego lub postanowienia mającego skutki wyroku uniewinniającego jest możliwe w trzech trybach nadzwyczajno-odwoławczych, tj. w trybie kasacji, wznowienia postępowania oraz stwierdzenia nieważności orzeczeń wydanych wobec osób represjonowanych za działalność na rzecz niepodległego bytu Państwa Polskiego. Otwarcie forum sądowego dla stron procesowych, a więc podmiotów, które bezpośrednio zainteresowane są rozstrzygnięciem o przedmiocie procesu, stanowi gwarancję realizacji zasady bezpośredniości, kontradyktoryjności, równości broni, ustności, prawa do obrony oraz szeroko interpretowanej zasady rzetelności. W procedurach rehabilitacyjnych zorientowanych na ostateczne pozbawienie oskarżonego stygmatu osoby skazanej szczególnie istotne jest otwarcie forów procedowania w przedmiocie zasadności nadzwyczajnego środka odwoławczego, dopiero bowiem obalenie wyroku stwierdzającego winę rzekomego sprawcy warunkuje dalsze starania o prawidłowe rozstrzygnięcie kwestii odpowiedzialności karnej oskarżonego. Z kolei fora będące miejscem ponownego rozpoznania kwestii odpowiedzialności karnej, odbywające się po uchyleniu wyroku skazującego przed sądem odwoławczym lub sądem in meriti, pozostają otwarte dla oskarżonego i jego obrońcy według reguł dotyczących jawności wewnętrznej, obowiązujących w toku 
każdej rozprawy głównej i apelacyjnej. Dostęp oskarżonego do forów będących miejscem rozpoznania zasadności nadzwyczajnego środka odwoławczego lub ponownego rozpoznania kwestii odpowiedzialności karnej stanowi prawnomiędzynarodowy standard potwierdzony orzecznictwem Europejskiego Trybunału Praw Człowieka, konsekwentnie przyjmującego, że jawne wewnętrznie rozpoznanie sprawy stanowi element zasady rzetelnego procesu, mającej zastosowanie zarówno w głównym stadium sądowym, jak i w postępowaniu odwoławczym, kasacyjnym i postępowaniach stanowiących dalsze etapy odpowiedniego procesu karnego, implikujące skutki istotne dla oskarżonego. Sposób uregulowania kwestii dostępu oskarżonego i jego obrońcy do forów procedowania w przedmiocie nadzwyczajnych środków odwoławczych i forów ponownego rozpoznania sprawy nie budzi zastrzeżeń. Zasadą pozostaje bowiem możliwość fakultatywnego udziału oskarżonego $\mathrm{w}$ forach stanowiących miejsce dokonywania czynności zmierzających do wykazania prawdopodobieństwa zaistnienia lub pewności co do zaistnienia podstawy nadzwyczajnego środka odwoławczego, zaś ograniczenie, wyłączenie lub poszerzenie zakresu stawiennictwa rehabilitowanego stanowią ściśle określone exceptiones. Uwzględniając sposób otwarcia procedur rehabilitacyjnych i ponownie odbywających się postępowań w przedmiocie odpowiedzialności karnej, można wyodrębnić następujące formy jawności wewnętrznej:

a) dostęp stanowiący bezwzględne prawo rehabilitowanego i jego obrońcy, niewarunkowane jakimikolwiek dodatkowymi wymogami - fakultatywne uczestnictwo $\mathrm{w}$ forach rehabilitacyjnych i w postępowaniach ponownych dotyczy rozprawy kasacyjnej; podobnie otwarte dla oskarżonego pozostaje posiedzenie odbywające się $\mathrm{w}$ przedmiocie wznowienia postępowania, sprzężone ze sprawdzeniem okoliczności faktycznych, posiedzenie stanowiące forum orzekania $\mathrm{w}$ przedmiocie stwierdzenia nieważności orzeczeń represjonujących działaczy opozycyjnych oraz wszystkie rozprawy toczące się $\mathrm{w}$ ponownym postępowaniu przed sądem odwoławczym lub powtórnie orzekającym sądem in meriti;

b) dostęp stanowiący bezwzględne prawo rehabilitowanego, warunkowane jednak dopełnieniem przez niego określonych formalności lub/i decyzją uprawnionego organu sądowego - ograniczenie dostępu dotyczy oskarżonego znajdującego się w warunkach detencji, jego fakultatywny udział w rozprawie kasacyjnej jest warunkowany decyzją Prezesa Sądu Najwyższego lub Sądu Najwyższego, dostęp do rozprawy apelacyjnej odbywającej się w postępowaniu ponownym warunkuje z kolei pozytywna decyzja sądu odwoławczego, podejmowana wskutek złożenia przez rehabilitowanego wniosku o doprowadzenie go na forum sądu odwoławczego, dla otwarcia ponownej rozprawy głównej wystarczające jest samo złożenie wniosku o doprowadzenie; 
c) dostęp stanowiący obowiązek rehabilitowanego - obowiązkowy udział oskarżonego stanowi wyjątek implikowany ex lege lub ex institutio, tj. na podstawie decyzji uprawnionego czynnika sądowego, ustawowy obowiązek stawiennictwa oskarżonego funkcjonuje wyłącznie $\mathrm{w}$ ponownym postępowaniu przed sądem in meriti we fragmentach rozprawy głównej w sprawach o zbrodnię, z kolei zobowiązanie do stawiennictwa, kreowane odpowiednią decyzją organów sądowych, dotyczy ponownej rozprawy głównej (zobowiązanie do stawiennictwa może nałożyć przewodniczący lub sąd) oraz rozprawy odwoławczej (obligacje udziału implikuje decyzja prezesa sądu lub sądu);

d) obligatoryjny lub fakultatywny dostęp do forum co do zasady niejawnego, implikowany wyłącznie decyzją właściwego czynnika sądowego - decyzja kreująca prawo lub obowiązek otwiera zasadniczo zamknięte dla udziału stron posiedzenie w przedmiocie wznowienia postępowania (jej podjęcie stanowi prerogatywę prezesa sądu lub sądu wznowieniowego);

e) nieobecność $\mathrm{w}$ trakcie forów toczących się z obligatoryjnym udziałem rehabilitowanego, zobowiązanego do stawiennictwa ex lege lub ex institutio decyzją uprawnionego czynnika sądowego - rezygnacja z obowiązkowej obecności oskarżonego znajdującego się w procedurze rehabilitacyjnej dotyczy wskazanych ustawą przypadków obstrukcyjnego zachowania się oskarżonego, uniemożliwiającego lub utrudniającego przeprowadzenie rozpraw odbywających się przed Sądem Najwyższym w trybie kasacji oraz $\mathrm{w}$ postępowaniach ponownych, prowadzonych po uchyleniu wyroku wskutek uwzględnienia kasacji lub wznowienia postępowania. Salve veritate uprawnione wydaje się przyjęcie, że przypadki obstrukcji ze strony walczących o odzyskanie statusu osoby niekaranej będą rzadkie, niemniej, by uniknąć możliwej bezradności sądu wobec obstrukcji procedury rehabilitacyjnej przez objętą nią osobę, dopuszczalność stosowania przepisów antyobstrukcyjnych nie może budzić wątpliwości;

f) wyłączenie dostępu stron i ich przedstawicieli - całkowicie niejawne wewnętrznie pozostają posiedzenia odbywające się $\mathrm{w}$ ramach tzw. szybkiej ścieżki rehabilitacyjnej, obejmującej najpierw badanie zaistnienia podstawy kasacji lub podstawy propter nova, następnie zaś ewidentnej niesłuszności wyroku skazującego i, w konsekwencji, następcze uniewinnienie rehabilitowanego. Wewnętrzna niejawność odbywa się więc $\mathrm{w}$ warunkach braku potrzeby dodatkowych ustaleń co do okoliczności sprawy i winy sprawcy, ergo dostęp stron do forum rozpoznającego jednoznaczną i niebudzącą wątpliwości kwestię odpowiedzialności karnej jest zbędny, a procedowanie absente reo nie narusza standardu postępowania. 
W szerszym zakresie otwarte są procedury rehabilitacyjne dla obrońcy oskarżonego znajdującego się w procedurze rehabilitacji, dla skutecznej reprezentacji interesów przywracanego do grona osób prawnie niewinnych obrońca został bowiem zobligowany do stawiennictwa także w niektórych przypadkach forów odbywających się z fakultatywnym udziałem samego zainteresowanego. Na profesjonalnego reprezentanta rehabilitowanego nałożono bowiem obowiązek uczestnictwa w rozprawie kasacyjnej, odwoławczej oraz głównej, we wszystkich przypadkach formalnej obrony obligatoryjnej ustanawianej dla oskarżonego z przyczyn podmiotowych oraz przedmiotowych. Obowiązkowe stawiennictwo obrońcy może też stanowić swoisty ekwiwalent fakultatywnego udziału oskarżonego; zastępczy obligatoryjny udział dotyczy obrońcy oskarżonego, którego, wbrew żądaniu, nie sprowadzono na rozprawę apelacyjną z miejsca odosobnienia, uznając jednocześnie, że jego prawny interes będzie wystarczająco reprezentowany przez obrońcę.

\section{Bibliografia}

\section{Literatura}

AjDuKIEwICz K.: O sprawiedliwości. W: IDEM: Język i poznanie. T.1. Warszawa 2006. ARystoteles: Etyka nikomachejska. Ksiega V. Tłum. D. GromsKa. W: Idem: Dzieła wszystkie. Warszawa 2002.

BanaszCzyK T.: Pojęcie sprawiedliwości u Arystotelesa. „Studia filozoficzne” 1973, Z. 1.

Baracz M.: Pojęcie i cechy „uczciwego procesu karnego”. PiP 1991, z. 12.

BitYJ M., MuRzYNowski A.: Wznowienie postępowania karnego $w$ PRL w świetle prawa i praktyki. Warszawa 1980.

BŁaszyK M., PaluszKiewicz H.: Jawność rozprawy głównej po nowelizacji Kodeksu postępowania karnego. W: Verba volant, scripta manent. Proces karny, prawo karne skarbowe i prawo wykroczeń po zmianach z lat 2015-2016. Księga pamiątkowa poświęcona Profesor Monice Zbrojewskiej. Red. T. GRZEgORCZYK, R. OlszewsKi. Warszawa 2017.

BOROWIEC J.: Wojskowa prokuratura sądów doraźnych $w$ województwie rzeszowskim maj-czerwiec 1946. W: Przestępstwa sędziów i prokuratorów w Polsce lat 19441956. Red. W. KuLEsZA, A. RzEPLIŃsKi. Warszawa 2000.

BorucKa-Arctowa M.: Koncepcja sprawiedliwości proceduralnej i jej rola w okresie przemian systemu prawa - analiza teoretyczna i funkcjonalna. W: Dynamika wartości w prawie. Red. K. PAŁECKI. Kraków 1997.

Brighouse H.: Sprawiedliwość. Warszawa 2007.

CHMIELARCZYK W.: Problemy legislacyjne z zakresu prawa karnego materialnego $i$ procesowego $w$ Polskich Sitach Zbrojnych $w$ ZSRR oraz $w$ wojsku polskim $w$ latach 1943-1945. „Wojskowy Przegląd Prawniczy” 1990, z. 4. 
CIEŚlak M.: Podstawowe prawa i wolności w Europejskiej Konwencji Praw Człowieka na tle orzecznictwa Europejskiego Trybunatu Praw Człowieka w okresie 19881992. Warszawa 1995.

Cieślak M.: Polska procedura karna. Podstawowe założenia teoretyczne. W: IdEM: Dzieła wybrane. T. 2. Red. S. Waltoś przy współpracy M. Rusinka i S. STEINBorna. Kraków 2011.

Сıосн P.: Odpowiedzialność Skarbu Państwa z tytułu niestusznego skazania. Warszawa 2007.

CYPRIAN T., SAWICKI J.: Siedem procesów przed Najwyższym Trybunatem Narodowym. Poznań 1962.

Czaja J., Stelmach J.: W stronę proceduralnej teorii sprawiedliwości. „Logos i Ethos” 1993, z. 2.

CzARnecki P.: Skarga na wyrok sadu odwoławczego. (Non)sens nowego rozdziału 55 a K.p.k. CPKNP 2016, z. 2.

Czarnota A., Hofmański P.: Prawo, historia, sprawiedliwość. Polska ustawa o uznaniu za nieważne orzeczeń wydanych wobec osób represjonowanych za działalność na rzecz niepodległego bytu Państwa Polskiego a zasady rządów prawa. W: Aktualne problemy prawa karnego i kryminologii. Red. E. PŁYWACZEWsKI. Białystok 1998.

Czeszejкo-Sochacki Z.: Prawo do sqdu w świetle Konstytucji Rzeczypospolitej Polskiej (Ogólna charakterystyka). PiP 1997, z. 11-12.

Czeszejкo-Sochacki Z.: Prawo do sadu w świetle Konstytucji Rzeczypospolitej Polskiej. Prok. i Pr. 1997, z. 11-12.

DaszKiewicz W.: Glosa do wyroku Sądu Najwyższego z dnia 17 marca 1981 r., II KR 319/79. PiP 1982, z. 11.

DaszKiewicz W.: Prawo karne procesowe. Zagadnienia ogólne. T. 1. Poznań 1999.

DASzKIEWICZ W.: Problem rehabilitacji i odszkodowań za bezprawne represje karne. PiP 1990, z. 2.

Daszkiewicz W., Nowak T., Stachowiak S.: Proces karny. Część szczególna. Poznań 1996.

Drajewicz D.: Nieobecność oskarżonego na rozprawie głównej (art. 377 K.p.k.). Prok. i Pr. 2014, z. 7-8.

Drohomirecki J.: Saqdownictwo wojskowe w Polsce Ludowej. PiP 1971, z. 2.

DwORKIN R.: Biorąc prawa poważnie. Warszawa 1998.

EICHSTAEDT K.: Postępowania szczególne w polskim procesie karnym. Warszawa 2010.

FAjst M.: Komisja Specjalna na tle innych instytucji quasi-sadowych. W: Przestępstwa sędziów i prokuratorów w Polsce lat 1944-1956. Red. W. KulESZA, A. RzEPLIŃsKI. Warszawa 2000.

FInGas M., SteInborn S.: Granice rozpoznania sprawy $w$ instancji odwoławczej $w$ świetle nowelizacji Kodeksu postępowania karnego z dnia 27 września 2013 r. i 20 lutego 2015 r. W: Obrońca $i$ petnomocnik $w$ procesie karnym po 1 lipca 2015 r. Przewodnik po zmianach. Red. P. WiLIŃsKI. Warszawa 2015.

Garlicki L.: Prawo do sądu (rozważania de lege fundamentale ferenda). AUMCS 1990, z. 37.

GrzegorczyK T.: Kodeks postępowania karnego oraz ustawa o świadku koronnym. Kraków 2008. 
GRZEgORCZYK T.: O niektórych uproszczeniach procedury karnej w nowym Kodeksie postępowania karnego. PS 1997, z. 9.

GrZEgorczyK T.: Orzekanie pod nieobecność oskarżonego w postępowaniu karnym zwyczajnym $w$ świetle nowego kodeksu postępowania karnego. W: Nowe prawo karne procesowe. Poznań 1999.

GRZEGORCZYK T.: Udziat stron i innych uczestników procesu $w$ posiedzeniach sqdu $w$ sprawach karnych. W: Nauki penalne wobec problemów współczesnej przestępczości. Księga jubileuszowa z okazji 70. rocznicy urodzin profesora Andrzeja Gaberle. Red. K. KrajewsKi. Warszawa 2007.

GrześKowiaK A.: Sady tajne w latach 1944-1956. W: Prawo okresu stalinowskiego. Zagadnienia wybrane. SI 1992, t. 22.

Hofmański P.: Europejska Konwencja Praw Człowieka i jej znaczenie dla prawa karnego materialnego, procesowego i wykonawczego. Białystok 1993.

HofMAŃsKi P.: Orzeczenie sadu kasacyjnego. W: Aktualne problemy prawa i procesu karnego. Ksiega ofiarowana profesorowi Janowi Grajewskiemu. Red. M. PŁachTa. GSP 2003, t. 11.

Hofmański P., Wróbel A.: Prawo do rzetelnego procesu sądowego. W: Konwencja o Ochronie Praw Człowieka i Podstawowych Wolności. T. 1. Komentarz do art. 1-18. Red. L. GarLicki. Warszawa 2010.

HofmańsKi P., ZabŁocki S.: Sprawność postępowania odwoławczego $w$ świetle noweli do Kodeksu postępowania karnego z 27.9.2013 r. W: Między naukq a praktyka prawa karnego. Ksiega Jubileuszowa Profesora Lecha Gardockiego. Red. Z. JęDRZEJEWSKI et al. Warszawa 2014.

HofMAŃsKi P., SADZIK E., ZgrYZEK K.: Kodeks postępowania karnego. T. 1: Komentarz do art. 1-296. Red. P. HofMAŃsKi. Warszawa 2004.

Hofmański P., SADZIK E., ZgryzeK K.: Kodeks postępowania karnego. T. 2: Komentarz do artykułów 297-467. Red. P. HofMAŃsKi. Warszawa 2004.

HofmańsKi P., SADZIK E., ZgrYZeK K.: Kodeks postępowania karnego. T. 3: Komentarz do artykułów 468-682. Red. P. HofMAŃsKi. Warszawa 2004.

Huzar E.: Glosa do wyroku Sądu Najwyższego z dnia 17 marca 1981 r., II KR 319/79. OSPiKA 1981, z. 9.

JAKUBOwski G.: Sadownictwo powszechne w latach 1944-1950. Warszawa 2002.

JASIŃsKi W.: Jawność postępowania jako warunek rzetelnego procesu karnego w orzecznictwie Europejskiego Trybunału Praw Człowieka. W: System wymiaru sprawiedliwości a media. Red. C. Kulesza. Białystok 2009.

JasińsKi W.: Jawność wewnętrzna postępowania sadowego. W: Jawność procesu karnego. Red. J. SkorupKa. Warszawa 2012.

JAsIŃSKI W.: Odszkodowanie za niestuszne skazanie, tymczasowe aresztowanie lub zatrzymanie. W: Kodeks postępowania karnego. Komentarz. Red. J. SKorupKA. Warszawa 2015.

Jörg A., WeIgEND E.: Prawo karne, zmiana systemu politycznego i obrachunek z przeszłościq w Polsce i Niemczech. Próba podsumowania. W: Materiały z polsko-niemieckiej konferencji „Prawo karne a problem zmiany ustroju politycznego”. Kraków 30 wrzesień-3 październik 1996. Kraków 1996. 
KAFTAL A.: Jawność postępowania karnego w świetle nowego kodeksu postępowania karnego. NP 1969, z. 11-12.

Kaftal A.: Kontrola prawomocnych orzeczeń w polskim procesie karnym. Warszawa 1971.

Kaftal A.: Niektóre zagadnienia wznowienia postępowania sądowego. Pal. 1971, Z. 7-8.

KaFtal A.: Wznowienie postępowania zakończonego prawomocnym orzeczeniem sqdu wedtug nowego K.p.k. PiP 1970, z. 6.

Kala D.: Obrońca $w$ postępowaniu $w$ sprawach o wydanie wyroku łącznego. Pal. 2003, z. 7-8.

KALINOwSKI S.: Rozprawa główna w polskim procesie karnym. Warszawa 1975.

Kallas M., LitYŃsKi A.: Historia ustroju i prawa Polski Ludowej. Warszawa 2000.

KARCZMARZYK M.A., Rogoziński P.: Udział oskarżonego pozbawionego wolności na rozprawie przed sadem odwoławczym. Pal. 1997, z. 3-4.

Kauba K.: Przywracanie praw skazanym w latach 1944-1956. EP 1994, z. 3.

Kauba K.: Ustawa rehabilitacyjna. SI 1995, z. 27.

Klejnowska M.: Dowodzenie co do meritum $w$ sprawie karnej $w$ postępowaniu apelacyjnym. RPEiS 2007, z. 1.

Klejnowska M.: Prawo do samodzielnej i rozsadnej obrony $w$ świetle nowelizacji Kodeksu postępowania karnego z dnia 27 września 2013 r. W: Wokół gwarancji współczesnego procesu karnego. Księga jubileuszowa profesora Piotra Kruszyńskiego. Red. B.T. BieńKowsKa, H. GajewsKa-KraczKowsKa, M. RogacKA-RzEWNICKA. Warszawa 2015.

KuImowa J.: W kwestii nowych faktów lub dowodów jako podstawy wznowienia postępowania karnego. Pal. 1974, z. 10.

KŁaK Cz.P.: Postępowanie nakazowe $w$ polskim procesie karnym a ochrona praw człowieka. Warszawa 2008.

KŁODAwsKi M.: Superfluum i nadwyżki znaczeniowe jako przykłady redundancji tekstu prawnego. „Archiwum Filozofii Prawa i Filozofii Społecznej” 2013, z. 2.

KMIECIK R.: Formy przeprowadzania dowodu $w$ postępowaniu o wznowienie. NP 1982, z. 3-4.

Kochanowski J.: Prawo karne wobec upiorów przeszłości i wyzwań współczesności. SI 2000, z. 38.

KOPER R.: Jawność rozprawy głównej a ochrona prawa do prywatności $w$ procesie karnym. Warszawa 2010.

KruK E.: Postępowanie nakazowe. W: Tryby szczególne. System Prawa Karnego Procesowego. T. 14. Red. F. PrusaK. Warszawa 2015.

KuBIAK A.: Konstytucyjna zasada prawa do sądu w świetle orzecznictwa Trybunału Konstytucyjnego. Łódź 2006.

Kulesza C: Zasada jawności a prawo do obrony. W: System wymiaru sprawiedliwości i media. Red. C. Kulesza. Białystok 2009.

LECIAK M.: Wytączenie jawności rozprawy z uwagi na ochronę tajemnicy państwowej $w$ procesie karnym. PiP 2007, z. 2.

LERNELl L.: Wykład prawa karnego. Część ogólna. Warszawa 1961. 
LIPCZYŃSKA M.: Stanowisko oskarżonego $w$ procesie karnym Polski Ludowej. Warszawa 1956.

LITYŃSKI A.: „...prokuratura jest instrumentem...”. Kartka z dziejów prokuratury powszechnej Polski Ludowej. W: Współczesne problemy procesu karnego i wymiaru sprawiedliwości. Księga ku czci Profesora Kazimierza Marszała. Red. P. HofMańsKi, K. ZgrYZeK. Katowice 2003.

LiTYŃsKi A.: Historia ustroju i prawa Polski Ludowej. Warszawa 2013.

LITYŃsKi A.: Inaczej o pierwszej dekadzie Polski Ludowej. Obraz sądów karnych. W: Z dziejów prawa Rzeczpospolitej Polskiej. Red. A. LITYŃsKI. Katowice 1991.

LiTYŃsKi A.: O prawie i sq̨dach początków Polski Ludowej. Białystok 1999.

LITYŃsKi A.: Początki służby sprawiedliwości w Polskich Siłach Zbrojnych $w$ ZSRR (1943). W: Dawne prawo i myśl prawnicza. Prace historycznoprawne poświęcone pamięci Wojciecha Bartla. Red. A. Malec, W. UruszczaK. Kraków 1995.

LITYŃsKi A.: Rok 1943 w Polskich Siłach Zbrojnych w ZSRR: tworzenie wojskowego prawa sqdowego. W: Historia prawa - historia kultury. Liber Memorialis Vitoldo Maisel dedicatus. Prace Wydziału Prawa i Administracji UAM. T. I. Red. E. Borkowska, H. Olszewski. Poznań 1994.

LiTYŃsKi A.: Ustawodawstwo karne w pierwszych latach Polski Ludowej. W: Wojna domowa czy nowa okupacja? Polska po roku 1944. Red. A. AJNENKIEL. WrocławWarszawa-Kraków 1998.

LyONs D.: Etyka i rzady prawa. Warszawa 2000.

Ładoś S.: Watpliwości co do stanu zdrowia psychicznego jako przesłanka obligatoryjnej obrony formalnej. W: GARDOCKA T. et al.: Prawo do obrony w postępowaniu penalnym. Wybrane aspekty. Red. M. Kolendowska-MatejczuK, K. Szwarc. Warszawa 2014.

Makarewicz J.: Prawo karne. Wykład prawnoporównawczy z uwzględnieniem prawa obowiq̨zującego w Rzeczpospolitej Polskiej. Lwów-Warszawa 1924.

MaKarewicz J.: Prawo karne ogólne. Kraków 1914.

Maкоwsкi M.: Prawo karne - Część ogólna (Wykład prawnoporównawczy prawa karnego austriackiego, niemieckiego i rosyjskiego obowiązującego $w$ Polsce). Kraków 1924.

MaŁocha-Krupa A.: Stowa $w$ lustrze. Pleonazm - semantyka - pragmatyka. Wrocław 2003.

MANOWSKA M.: Etapy badania skargi o wznowienie postępowania (wybrane zagadnienia). PS 2004, z. 11-12.

Marsza€ K.: Proces karny. Zagadnienia ogólne. Katowice 2012.

MuRZYNOWSKI A.: Istota i zasady procesu karnego. Warszawa 1976.

MurzYNowsKi A.: Podstawy wznowienia postępowania karnego. NP 1970, z. 7-8.

Murzynowski A.: Ułaskawienie w Polsce Ludowej. Warszawa 1965.

MuszYŃsKi J.: Zasady ustrojowe sqdownictwa wojskowego i prokuratury wojskowej w Polsce Ludowej. Warszawa 1964.

NelKen J.: Nowe fakty $i$ dowody jako podstawa wznowienia postępowania sadowego. NP 1973, z. 6.

Nowicki M.A.: Wokół Konwencji Europejskiej. Komentarz do Europejskiej Konwencji Praw Człowieka. Warszawa 2010. 
NowikowsKi I.: Uwagi o zasadzie rzetelnego procesu karnego (kwestie wybrane). W: Rzetelny proces karny. Ksiega jubileuszowa Profesor Zofii Świdy. Red. J. SKORUPKA. Warszawa 2009.

OssowsKa M.: Normy moralne. Próba systematyzacji. Warszawa 1985.

PAPIERKOWSKI Z.: Rehabilitacja i zatarcie skazania a zniesławienie. Warszawa 1934.

PAPRZYCKI L.: Oczywista bezzasadność i oczywista zasadność kasacji. W: Współczesne problemy procesu karnego i wymiaru sprawiedliwości. Księga pamiątkowa ku czci Profesora Kazimierza Marszała. Red. P. Hofmański, K. ZGrYZeK. Katowice 2003.

Perelman C.: O sprawiedliwości. Warszawa 1959.

PIEKARSKa K.M.: Naruszanie zasady jawności w „sadach tajnych”. W: Prawo karne w okresie stalinizmu. SI 1995, t. 27.

PŁachta M.: Prawnomiędzynarodowe i konstytucyjne podstawy ochrony praw oskarżonego w procesie karnym. GSP 1999, t. 4.

PonikowsKi R.: Granice jawności wewnętrznej i zewnętrznej przygotowawczego stadium postępowania karnego. W: Jawność procesu karnego. Red. J. SKorupKA, Warszawa 2012.

PRADEL J.: Rzetelny proces karny w europejskim prawie karnym. Prok. i Pr. 1996, z. 9.

PYszKowski A.: Bilans działalności sądów specjalnych. „Demokratyczny Przegląd Prawniczy" 1946, z. 11-12.

RAWLS J.: Teoria sprawiedliwości. Warszawa 2009.

REDELBACH A.: Zasada rzetelności postępowania $w$ rozstrzygnięciach organów strasburskich. RPEiS 1997, z. 2.

RejMan G.: Kodeks karny. Część ogólna. Komentarz. Warszawa 1999.

RogaCKA-RzEWNICKA M.: Znaczenie niepisanych regut postępowania dla tworzenia podstaw rzetelnego procesu karnego. W: Rzetelny proces karny. Ksiega jubileuszowa Profesor Zofii Świdy. Red. J. Skorupka. Warszawa 2009.

Rogoziński P.: Postępowanie dowodowe na rozprawie apelacyjnej $w$ sprawach karnych. SP 2010, z. 1.

RYNKUN-WERnER R.: Adwokat z urzędu. Podstawowe zagadnienia prawne. Warszawa 2011.

RzEPLIŃSKI A.: Przystosowanie ustroju sadownictwa do potrzeb państwa totalitarnego $w$ Polsce $w$ latach 1944-1956. W: Przestępstwa sędziów i prokuratorów $w$ Polsce lat 1944-1956. Red. W. Kulesza, A. RzePlińsKi. Warszawa 2000.

SAdURSKI W.: Teoria sprawiedliwości. Podstawowe zagadnienia. Warszawa 1988.

SAKowICZ A.: Postępowanie dowodowe $w$ postępowaniu apelacyjnym. Zarys problematyki. W: Obrońca i petnomocnik $w$ procesie karnym po 1 lipca 2015 r. Przewodnik po zmianach. Red. P. Wiliński. Warszawa 2015.

SAwICKI J.: O prawie sąów specjalnych. W: Wymiar sprawiedliwości w odrodzonej Polsce. 22 VII 1944-22 VII 1945. Warszawa b.r.w.

SKORUPKa J.: Prawnomiędzynarodowe i konstytucyjne podstawy jawności procesu karnego. W: Jawność procesu karnego. Red. J. SKoruPKA. Warszawa 2012.

SKORUPKA J.: Sprawiedliwość proceduralna jako cel procesu karnego. W: Rzetelny proces karny. Księga jubileuszowa Profesor Zofii Świdy. Red. J. SKonuPKA. Warszawa 2009. 
SKRĘTOWICZ E.: Z problematyki rzetelnego procesu karnego. W: Rzetelny proces karny. Księga jubileuszowa Profesor Zofii Świdy. Red. J. SkorupKa. Warszawa 2009.

STACHOWIAK S.: Odszkodowanie za niestuszne skazanie, tymczasowe aresztowanie lub zatrzymanie w kodeksie postępowania karnego. Prok. i Pr. 1999, z. 1.

STEFAŃSKI R.A.: Konstytucyjne prawo do obrony a obrona obligatoryjna $w$ świetle noweli z dnia 27 września 2013 r. W: GARDOCKA T. et al: Prawo do obrony w postępowaniu penalnym. Wybrane aspekty. Red. M. KolendowsKa-MatejCZuK, K. SzWARC, Warszawa 2014.

STEFAŃsKi R.A.: Postępowanie przed sądem I instancji. W: Kodeks postępowania karnego. Komentarz. T. 2. Red. Z. GostYŃsKi. Warszawa 2004.

STEFAŃSKI R.A.: Obrona obligatoryjna $w$ polskim procesie karnym. Warszawa 2012.

STEFAŃSKI R.A.: Obrona obowiązkowa - prawo czy konieczność?. W: Współczesne tendencje $w$ rozwoju procesu karnego $z$ perspektywy dogmatyki oraz teorii i filozofii prawa. Red. J. SKORUPKA, I. Hä̈DUK-HawrYLAK. Warszawa 2011.

StEFAŃsKi R.A.: Postępowanie nakazowe. W: Kodeks postępowania karnego. Komentarz. T. 3. Red. Z. GostYŃsKi. Warszawa 2004.

STEFAŃsKi R.A.: Postępowanie nakazowe $w$ znowelizowanym Kodeksie postępowania karnego. Prok. i Pr. 2003, z. 7-8.

STEINBORN S.: Ksztattowanie granic rozpoznania sprawy $w$ instancji odwoławczej $w$ procesie karnym $w$ świetle nowelizacji kodeksu postępowania karnego z 27 września 2013 r. i 20 lutego 2015 r. W: Reforma prawa karnego materialnego i procesowego z 2015 r. Red. D. KaLA, I. ZgolińsKi. Warszawa 2015 r.

STEINBORn S.: Postępowanie dowodowe $w$ instancji apelacyjnej $w$ świetle nowelizacji Kodeksu postępowania karnego. Prok. i Pr. 2015, z. 1-2.

STEINBORN S.: Skarga na wyrok kasatoryjny sądu odwoławczego na tle systemu środków zaskarżenia $w$ polskim procesie karnym. W: Verba volant, scripta manent. Proces karny, prawo karne skarbowe i prawo wykroczeń po zmianach z lat 2015-2016. Księga pamiątkowa poświęcona Profesor Monice Zbrojewskiej. Red. T. GrzegorczyK. R. OlszewsKi. Warszawa 2017.

SychтA K.: Aksjologiczne i dogmatyczne aspekty prawnokarnego rozrachunku z przeszłościa dokonywanego w warunkach zmiany systemu politycznego. W: Profesor Marian Cieślak - osoba - dzieło - kontynuacje. Red. W. CieślaK, S. STEInborn. Warszawa 2013.

SychтA K.: Rehabilitacja osób represjonowanych $w$ latach 1944-1956 za działalność na rzecz niepodległego Państwa Polskiego. Katowice 2006.

SzumiŁo-KulczYcKa D.: Prawne warunki wznowienia postępowania sadowego. W: Środki zaskarżenia w procesie karnym. Księga pamiątkowa ku czci Profesora Zbigniewa Dody. Red. A. Gaberle, S. Waltoś. Kraków 2000.

Śliwiński S.: Wznowienie postępowania karnego w prawie polskim na tle porównawczym. Warszawa 1957.

ŚwiATŁowsKi D.: Wyrok łączny. W: Kodeks postępowania karnego. Komentarz. Red. J. SKORUPKA. Warszawa 2015.

ŚwIECKI D.: Bezpośredniość czy pośredniość w polskim procesie karnym. Warszawa 2012. 
ŚwIECKI D.: Obrona obligatoryjna na rozprawie apelacyjnej. W: Kodeks postępowania karnego. Komentarz do zmian 2016. Red. D. ŚwIECKI. Warszawa 2016.

ŚwIECKI D.: Rozprawa apelacyjna w polskim procesie karnym. Kraków 2006.

ŚwIECKI D.: Skarga na wyrok sądu odwoławczego. W: Kodeks postępowania karnego. Komentarz do zmian 2016. Red. D. ŚwIECKI. Warszawa 2016.

TOKARCzyK R.A.: Filozofia prawa $w$ perspektywie prawa natury. Białystok 1997.

TuleyA I.: Ustawa o uznaniu za nieważne orzeczeń wydanych wobec osób represjonowanych za działalność na rzecz niepodległego bytu Państwa Polskiego. Komentarz praktyczny. Warszawa 2013.

TurlejSKA M.: Sądy na kółkach. Głos przeciwko karze śmierci. „Przegląd Powszechny" 1988, z. 12.

Tylman J.: Postępowanie przed sadem pierwszej instancji. Warszawa 1999.

Tylman J.: Rozwój systemu postępowania przygotowawczego w latach 1944-1956. W: „Zeszyty Naukowe Uniwersytetu Łódzkiego” 1957, z. 6.

Urbaniak M.: Prowadzenie rozprawy pod nieobecność oskarżonego - art. 377 k.p.k. Prok. i Pr. 2002, z. 3.

URBANIAK M.: Rozpoznawanie spraw pod nieobecność oskarżonego w polskim procesie karnym. Poznań-Kalisz 2003.

WAsZCZYŃsKi J.: Odszkodowanie za niestuszne skazanie lub aresztowanie. Pal. 1974, Z. 11.

WĄSEK A.: Prawo oskarżonego pozbawionego wolności do udziatu w rozprawie odwoławczej. W: Środki zaskarżenia $w$ polskim procesie karnym. Księga pamiątkowa ku czci prof. Zbigniewa Dody. Red. A. Gaberle, S. Waltoś. Kraków 2000.

WĄSEK A.: Rzetelny proces karny. „Kościół i Prawo” 1998, t. 13.

WęDRYCHOwsKi M.P.: Prawo do „uczciwej rozprawy” w Europejskiej Konwencji Praw Człowieka. PS 1991, z. 5-6.

WiLIŃsKi P.: Konstytucyjny standard prawa do sądu a proces karny. W: Węzłowe problemy procesu karnego. Red. P. Hofmański. Warszawa 2010.

WiLIŃski P.: Pojęcie rzetelnego procesu karnego. W: Rzetelny proces karny $w$ orzecznictwie sądów polskich i międzynarodowych. Red. P. WiLIŃsKI. Warszawa 2009.

WilińsKi P.: Pojęcie rzetelnego procesu karnego. W: Skargowy model procesu. Ksiega ofiarowana Profesorowi Stanisławowi Stachowiakowi. Red. A. GERECKA-ŻoŁYŃsKa et al. Warszawa 2008.

WiLIŃski P.: Wspótczesne dyskusje o zasadach procesu karnego. W: System Prawa Karnego Procesowego. Zasady procesu karnego. T. 3. Cz. 1: Zasady procesu karnego. Red. P. WiLIński. Warszawa 2014.

Wiliński P.: Zasada prawa do obrony. W: System Prawa Karnego Procesowego. Zasady procesu karnego. T. 3. Cz. 2. Red. P. WiLIŃski. Warszawa 2014.

WiLIŃski P.: Zasada prawa do obrony w polskim procesie karnym. Warszawa 2006.

WILK L.: Ustawowa rehabilitacja osób represjonowanych za działalność na rzecz niepodległości Polski za działalność na rzecz niepodległości Polski. „Probl. Prawa Karnego" 1993, z. 19.

WisŁoскі C: Z zagadnień postępowania $w$ sprawach o odszkodowanie za niestuszne skazanie lub aresztowanie (art. 510-516 k.p.k.). Pal. 1958, z. 11. 
WoźNY T.: Charakter prawny postępowania o odszkodowanie za niestuszne skazanie, tymczasowe aresztowanie lub zatrzymanie. PiP 2004, z. 8.

WójcickA B.: Jawność postępowania sq̨dowego w polskim procesie karnym. Łódź 1989.

WróblewsKi B.: Penologia - Socjologia kar. T. 1. Wilno 1926.

ZabŁocki S.: Nadzwyczajne środki odwoławcze. W: Kodeks postępowania karnego. Komentarz. T. 3. Red. Z. Gostý́sKi. Warszawa 2004.

ZaвŁOCKI S.: Nowela K.p.k. z dnia 20 lipca 2000. Warszawa 2000.

ZАвŁOCKI S.: Sprawiedliwość proceduralna a współczesne trendy zwalczania przestępczości (na przykładach zmian w polskiej procedurze karnej). W: Prawo i godność. Ksiega pamiątkowa $w 70$ rocznicę urodzin Profesora Wojciecha Eq̨czkowskiego. Red. S. Fundowicz, F. Rymarz, A. GomuŁowicz. Lublin 2003.

ZABŁOCKI S.: Wznowienie postępowania karnego $w$ świetle przepisów nowego Kodeksu postępowania karnego. W: Nowa kodyfikacja karna. Kodeks karny. Kodeks postępowania karnego. T. 16. Red. L. BoguniA. Warszawa 1998.

ZAGRODNIK J.: Instytucja skargi na wyrok sqdu odwoławczego (rozdziat 55 a K.p.k.) zarys problematyki. W: Verba volant, scripta manent. Proces karny, prawo karne skarbowe i prawo wykroczeń po zmianach z lat 2015-2016. Ksiega pamiątkowa poświęcona Profesor Monice Zbrojewskiej. Red. T. GrzegorczyK. R. OlszewsKi. Warszawa 2017.

ZDUŃCZYK J.: Samowolne wydalenie się oskarżonego z rozprawy. „Gazeta Sądowa i Penitencjarna" 1968, z. 13.

ZGRYZEK K.: Obrona obligatoryjna - czy rzeczywiście konieczna? Uwagi na marginesie art. 79 k.p.k. W: Węzłowe problemy procesu karnego. Red. P. HofmańsKI. Warszawa 2010.

ZgryzeK K.: Prawo do obrony po nowelizacji wrześniowej: kilka uwag. W: Wokót gwarancji wspótczesnego procesu karnego. Księga jubileuszowa profesora Piotra Kruszyńskiego. Red. B.T. BieńKowsKa, H. GajewsKa-KraczKowsKa, M. RogacKA-RzEWNICKA. Warszawa 2015.

ZgryzeK K.: Zasada jawności. W: System prawa karnego procesowego. T. 3. Cz. 1: Zasady procesu karnego. Red. P. WiLIŃsKI. Warszawa 2014.

ZIEMBIŃsKi Z.: O pojmowaniu sprawiedliwości. Lublin 1992.

ZiEmbiński Z.: Sprawiedliwość społeczna jako pojęcie prawne. Warszawa 1996.

Zwolíśsk S.: Rola sqdownictwa wojennego Ludowego Wojska Polskiego $w$ represjonowaniu Armii Krajowej. W: Armia Krajowa. Dramatyczny epilog. Red. K. Komorowski. Warszawa 1994. 